\title{
ÁGUA SUBTERRÂNEA EM JOINVILLE - SC - Avaliação hidrogeológica do aqüífero fraturado
}

\author{
SÉRGIO BENJAMIN BAGGIO
}

Orientador: Prof. Dr. Aldo da Cunha Rebouças

DISSERTAÇÃO DE MESTRADO

COMISSÃO JULGADORA
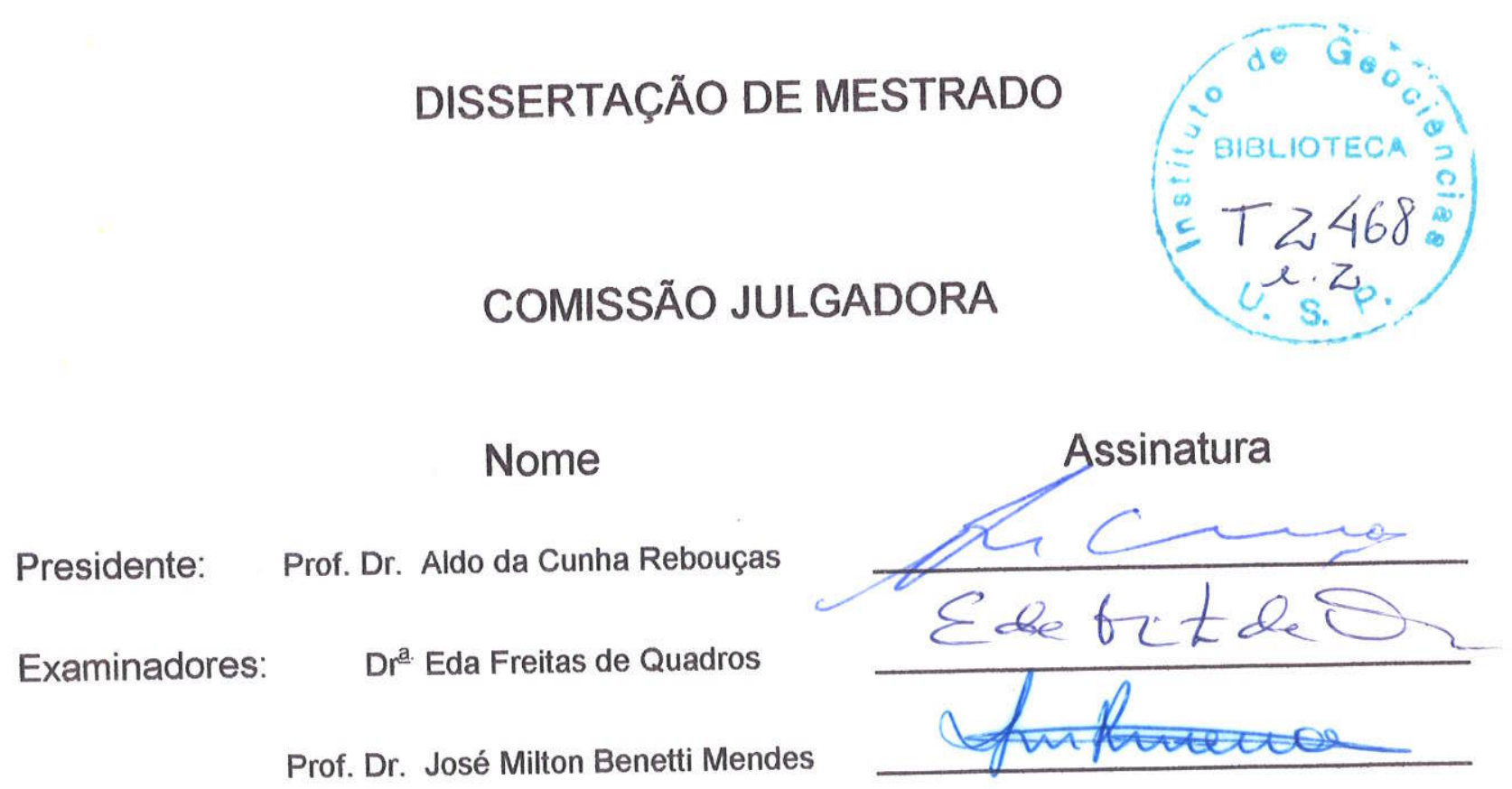

SÃO PAULO

1997 


\title{
UNIVERSIDADE DE SÃO PAULO INSTITUTO DE GEOCIÊNCIAS
}

\section{ÁGUA SUBTERRÂNEA EM JOINVILLE - SC Avaliação hidrogeológica do aqüífero fraturado}

\section{Sérgio Benjamin Baggio}

Orientador: Prof. Dr. Aldo da Cunha Rebouças

DISSERTAÇÃO DE MESTRADO

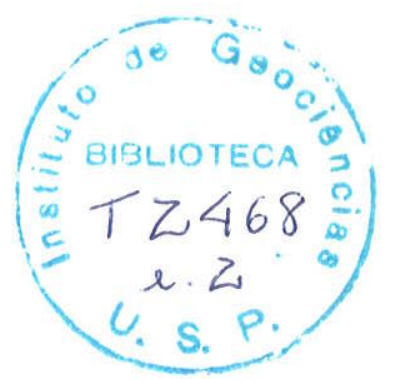

Programa de Pós Graduação em Recursos Minerais e Hidrogeologia

\author{
SÃO PAULO - SP
}

1997

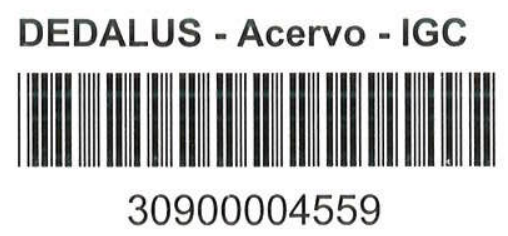


Aos meus Pais,

Santa Martello Baggio

e

Luiz Baggio (in memoriam) 


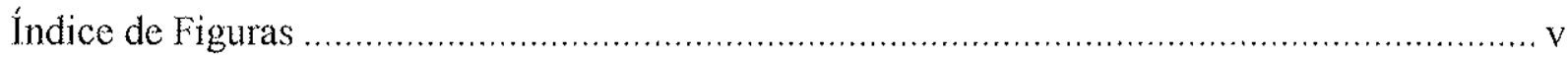

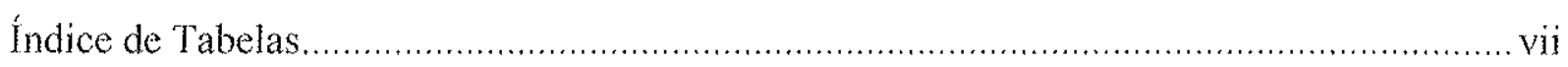

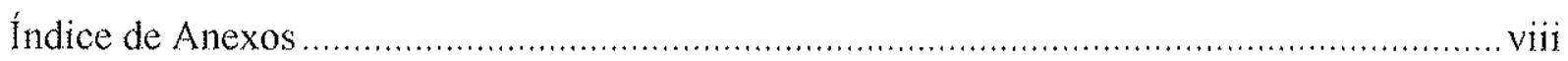

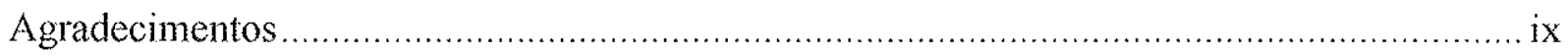

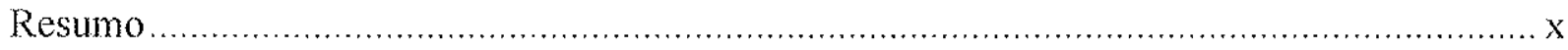

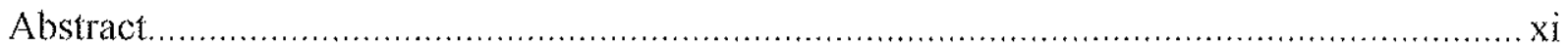

Página

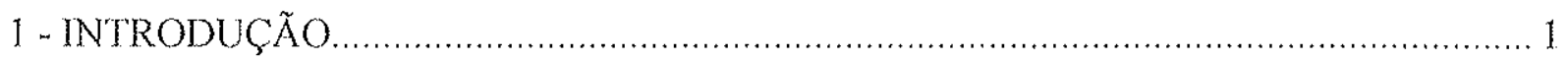

1.1 - Considerações sobre a área de estudo ............................................................ 1

1.2 - Considerações sobre o estudo desenvolvido ................................................. 2

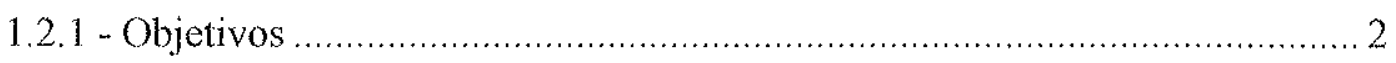

1.2.2 - Metodologia aplicada ................................................................... 3

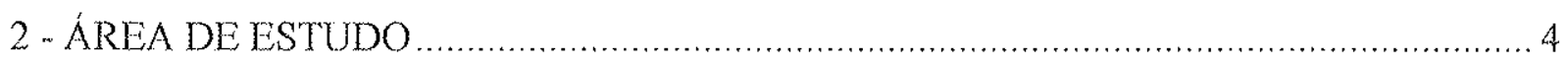

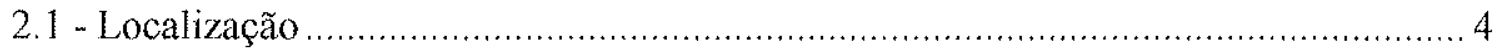

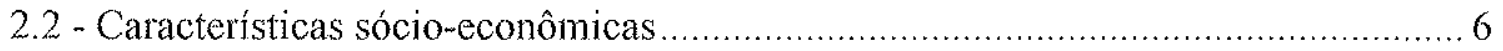

2.3 - Aspectos fisiográficos ................................................................................. 7

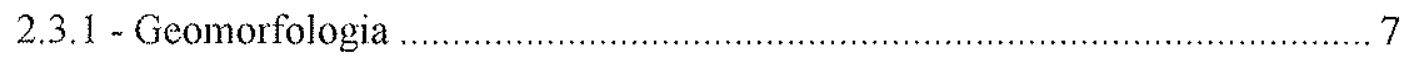

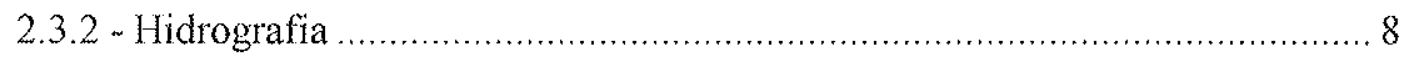

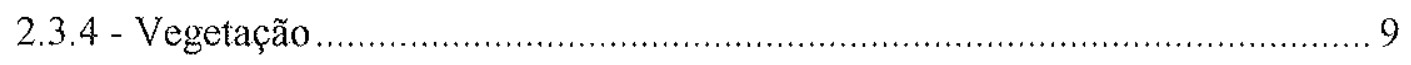

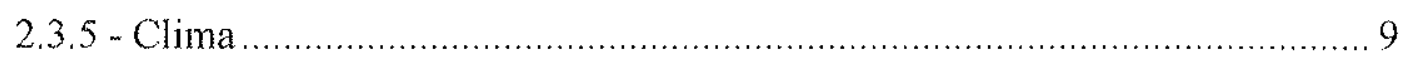

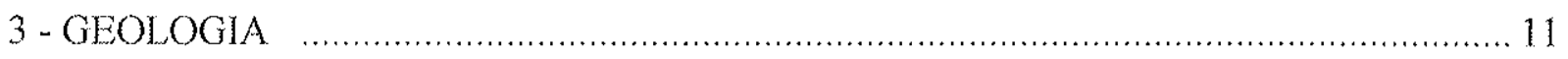

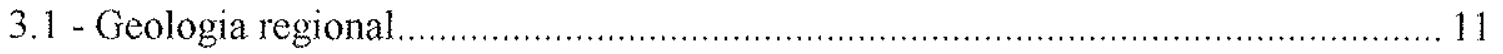

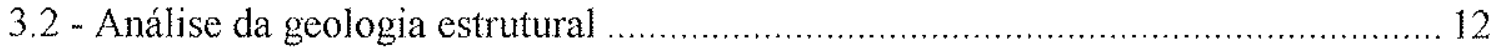

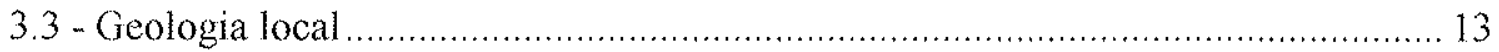

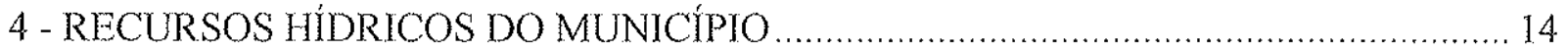

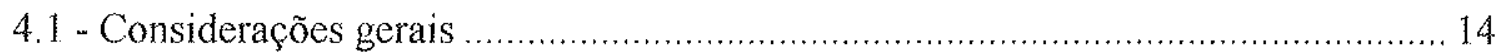

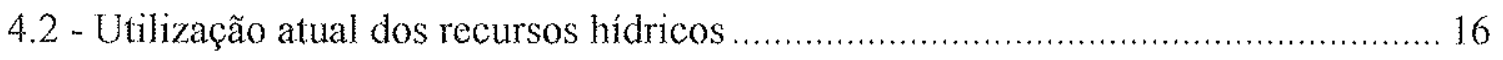

4.2.1 - Sistema de abastecimento de água - CASAN ................................... 16

4.2 .2 - Sistemas independentes de abastecimento de água subterrânea ............... 18

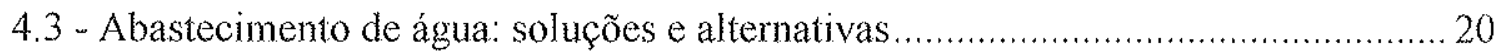




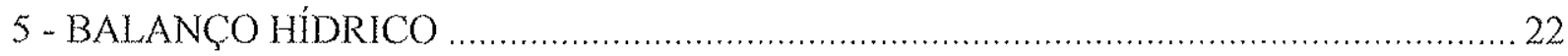

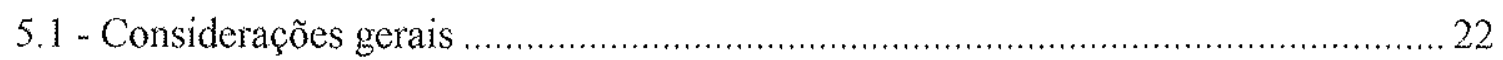

5.2 - Análise do balanço hídrico da Bacia do Rio Cachoeira .................................... 25

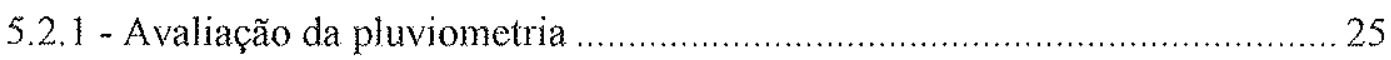

5.2 .2 - Avaliação da descarga fluvial ................................................. 28

5.2 .3 - Avaliação da evapotranspiração potencial ............................................ 29

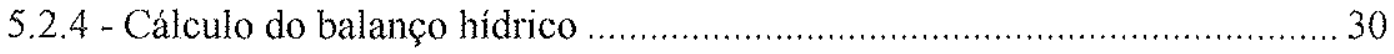

5.3 - Análise do balanço hídrico da Bacia do Rio Cubatão ..................................... 33

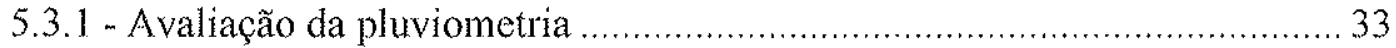

5.3 .2 - Avaliação da descarga fluvial ............................................................... 35

5.3 .3 - Avaliação da evapotranspiração potencial ................................................ 36

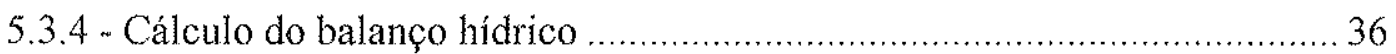

5.4 - Análise do balanço hídrico da Bacia do Rio do Júlio / Itapocuzinho ................... 38

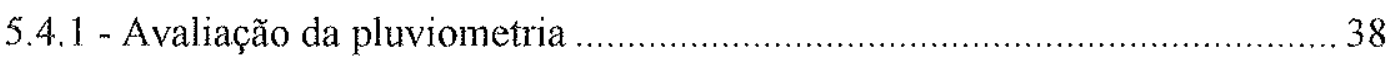

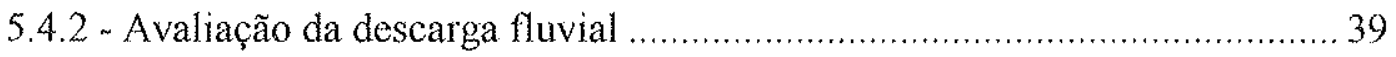

5.4 .3 - Avaliação da evapotranspiração potencial ............................................. 39

5.4 .4 - Cálculo do balanço hídrico ............................................................. 40

5.5 - Análise do balanço hídrico da Bacia do Rio Pirai ................................................ 41

5.5 .1 - Avaliação da pluviometria ............................................................. 41

5.5.2 - Avaliação da descarga fluvial ........................................................... 42

5.5 .3 - Avaliação da evapotranspiração potencial ........................................4.42

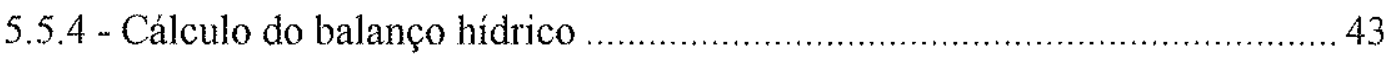

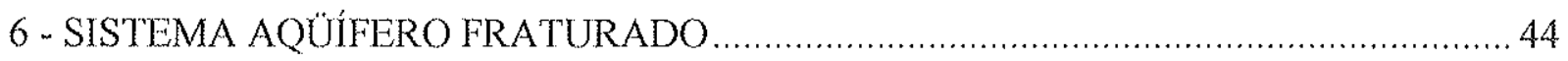

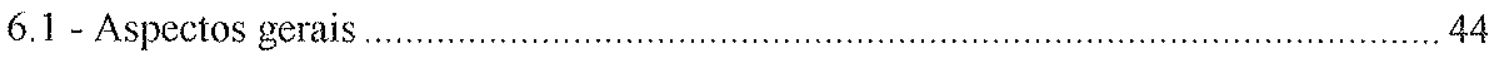

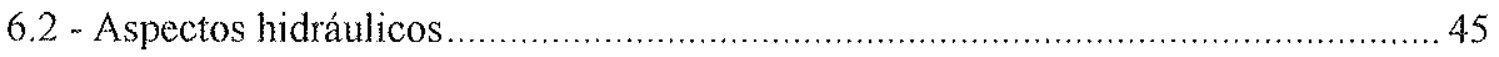

7 - ANÁLISE HIDROGEOLÓGICA DO AQÜÍFERO FRATURADO DE JOINVILLE _...... 48

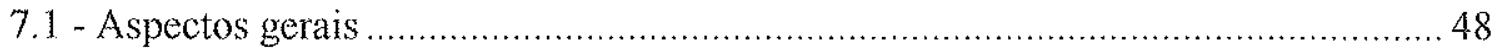

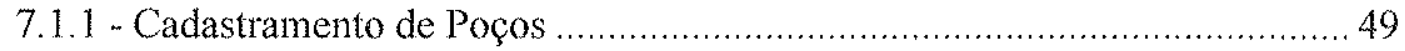

7.1 .2 - Histórico das perfurações ............................................................................. 50

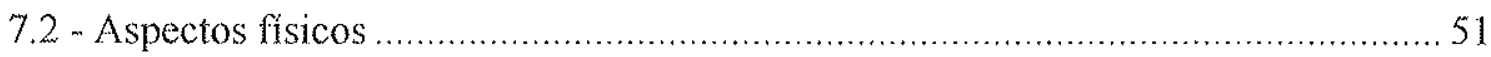

7.2 .1 - Profundidades do manto de intemperismo...................................... 51

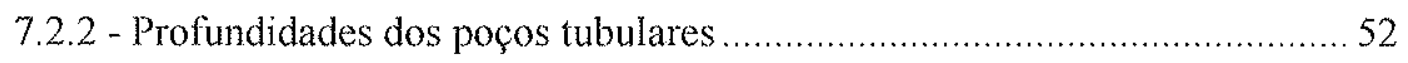

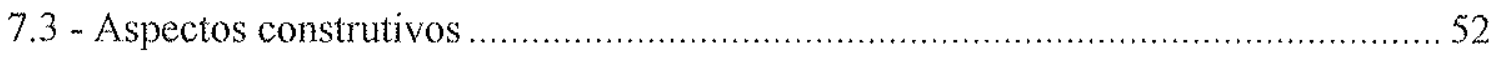

7.3 .1 - Perfuraçẫo ............................................................................ 53 
7.3.2 - Instalação de colunas de revestimento e seções de filtro

7.3 .3 - Problemas em colunas de revestimento e filtros .....................................5 56

7.3.4 - Cimentação do espaço anular para proteção sanitária ........................... 57

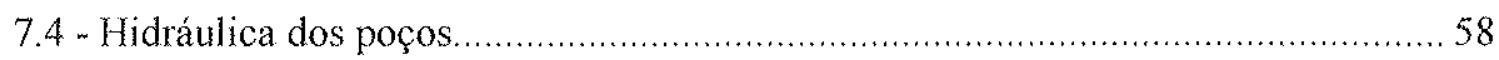

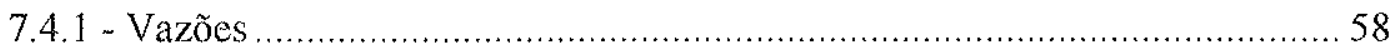

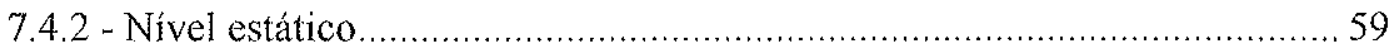

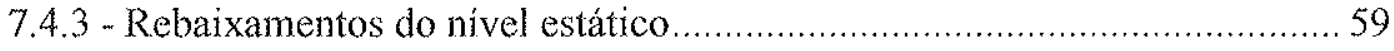

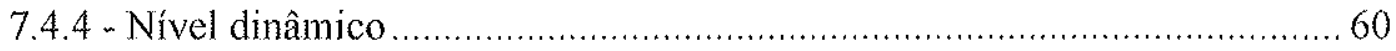

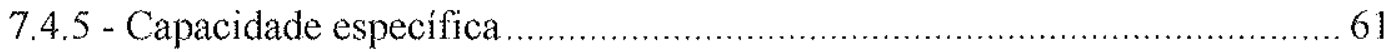

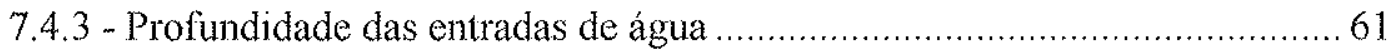

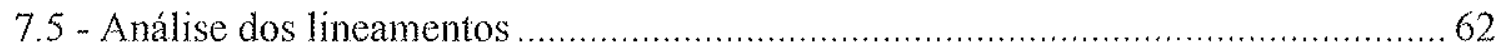

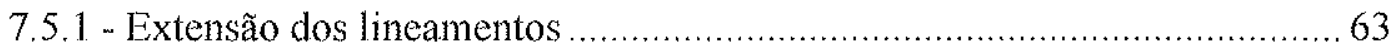

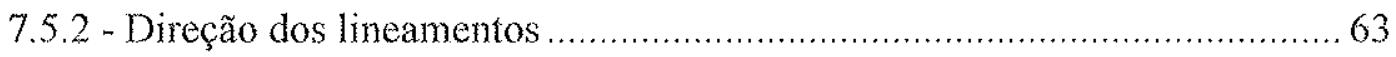

7.5 .3 - Relação entre lineamentos e produtividade ........................................66 66

7.6 - Hidroquímica das águas subterrâneas de Joinville .........................................67

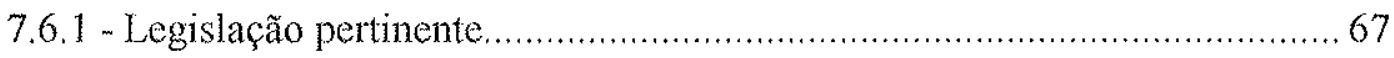

7.6.2 - Interação entre meio físico e a composição das águas ............................. 67

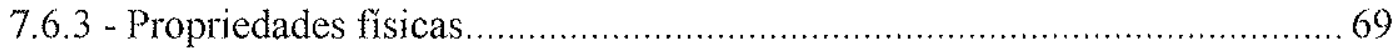

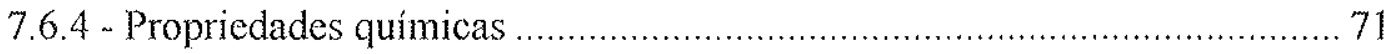

7.6.4.1 - Componentes orgânicos ........................................................... 71

7.6.4.2 - Componentes Inorgânicos............................................ 72

Alcalinidade, Acidez, pH ............................................................. 73

Sólidos Totais Dissolvidos ................................................................. 74

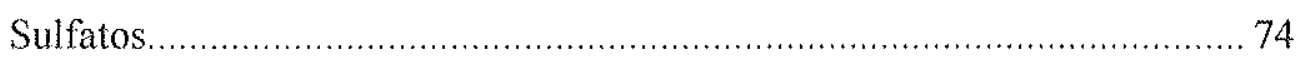

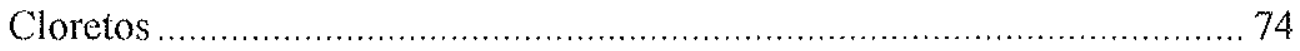

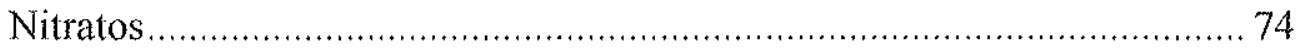

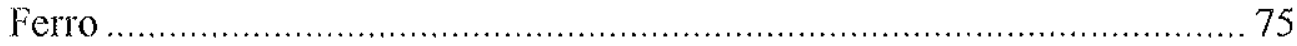

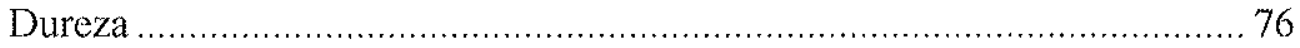

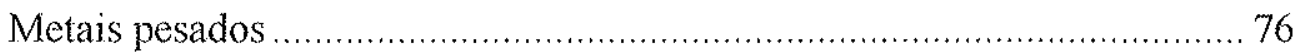

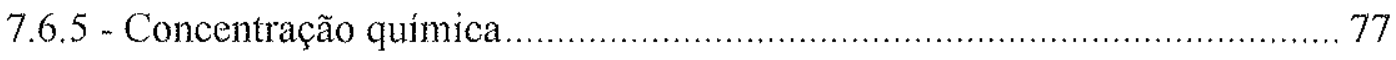

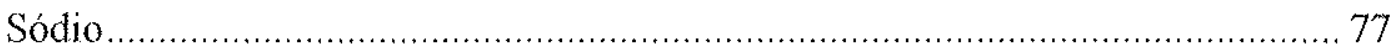

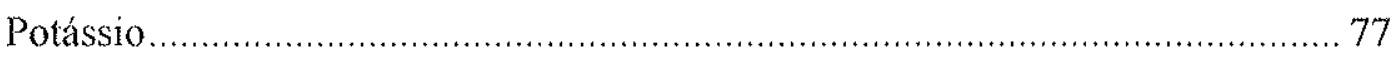

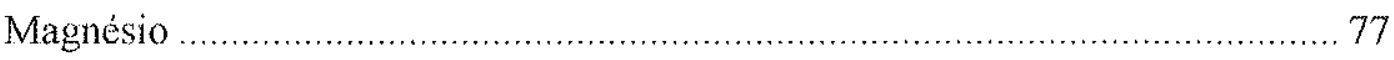

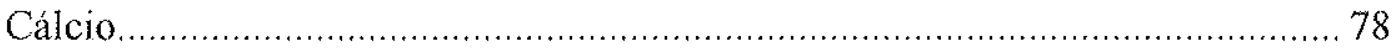




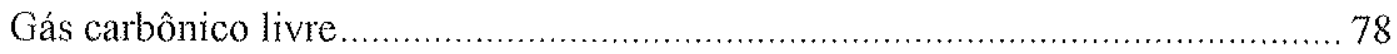

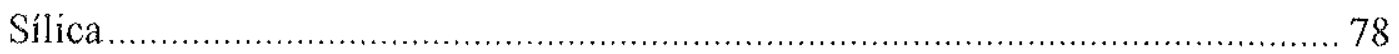

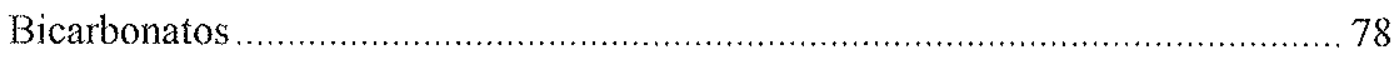

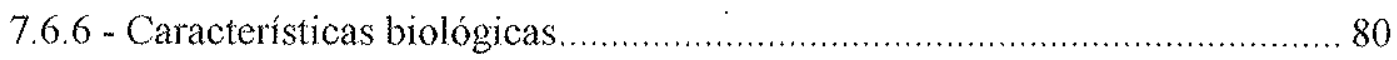

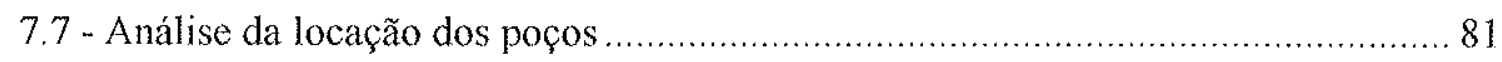

7.8. - Proposta de áreas favoráveis para a perfuração de poços.................................... 82

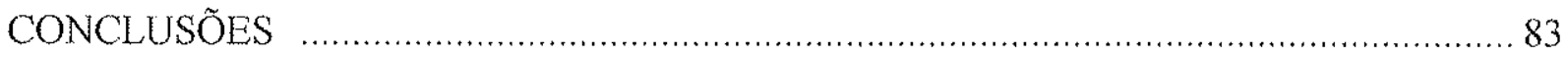

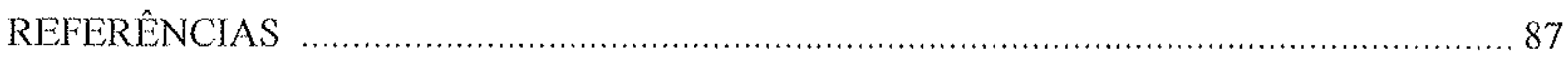

ANEXOS 
N. ${ }^{\circ}$ FIG. TÍTULO PÁG.

Figura 1 - Localização geográfica do município de Joinville - SC ...................................... 4.

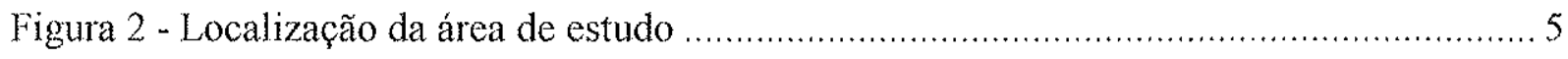

Figura 3 - Localização geográfica das bacias hidrográficas e das estações pluviométricas e

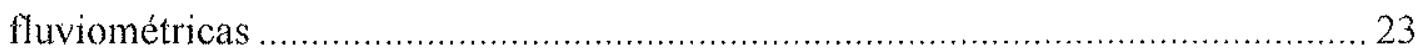

Figura 4 - Variação média mensal da pluviosidade. Estação RVPSC - DNAEE .................... 26

Figura 5 - Variação média mensal da pluviosidade. Estação Res. Norte - DNAEE .............. 27

Figura 6 - Variação média mensal da pluviosidade. Estação ETT ....................................... 28

Figura 7 - Variação média mensal da evapotranspiração. Estação ETT …….......................... 30

Figura 8 - Comportamento hídrico anual na Bacia do Rio Cachoeira ................................. 31

Figura 9 - Variação média mensal da pluviosidade. Estação DNAEE Salto 1 ..................... 34

Figura 10 - Variação média mensal da pluviosidade. Estação DNAEE Quiriri...................... 34

Figura 11 - Variação média mensal da descarga fluvial. Estação Salto 1 ............................ 35

Figura 12 -. Variação média mensal da evapotranspiração. Estação Salto 2 ….................... 36

Figura 13 - Comportamento hídrico anual na Bacia do Rio Cubatão ................................ 37

Figura 14 - Variação média mensal da pluviosidade. Estação DNAEE ….......................... 38

Figura 15 - Variação média mensal da descarga fluvial. Estação Rio do Júlio ...................... 39

Figura 16 - Variação média mensal da pluviosidade. Estação. DNAEE ............................. 41

Figura 17 . Variação média mensal da descarga fluvial. Rio Pirai ...................................... 42

Figura 18 - Variação média mensal da evapotranspiração. Gaplan (1986)........................... 43

Figura 19 - Frequência das perfurações executadas no período de 1970 a 1996 .................... 50

Figura 20 - Frequência das espessuras do manto intemperizado........................................51

Figura 21 - Frequência das profundidades dos poços .................................................. 52

Figura 22 - Frequência dos diâmetros iniciais das perfurações .......................................... 53

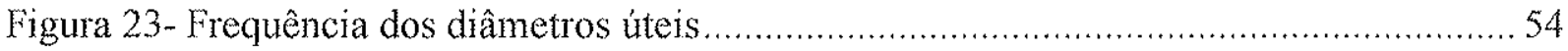

Figura 24 - Frequência dos intervalos de instalação dos filtros .......................................... 55

Figura 25 - Entradas de água x instalação de filtros............................................................... 55

Figura 26 - Frequência da profundidade da cimentação do espaço anular .......................... 57

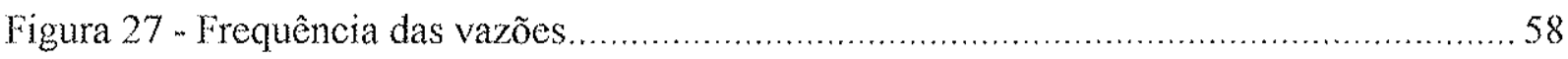

Figura 28 - Frequência do nível estático dos poços tubulares profundos ..............................59

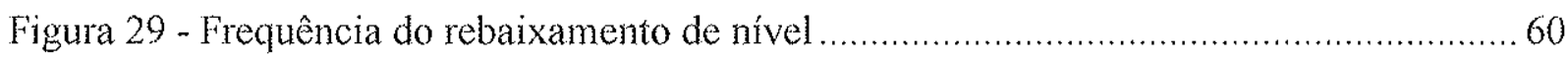

Figura 30 .. Frequência do nível dinâmico dos poços tubulares profundos .......................... 60 
Figura 31 - Frequência dos valores de capacidade especifica 61

Figura 32 - Frequência das profundidades das entradas de água ....................................62 62

Figura 33- Frequência da extensão dos lineamentos fotointerpretados ...............................63

Figura 34 - Frequência das direções dos lineamentos fotointerpretados............................. 64

Figura 35 . Diagrama de roseta dos lineamentos fotointerpretados ................................. 64

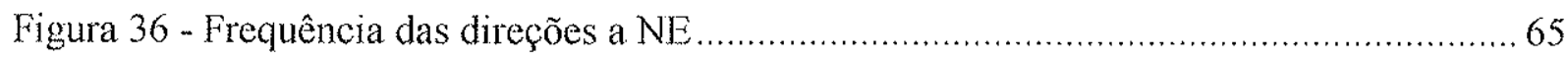

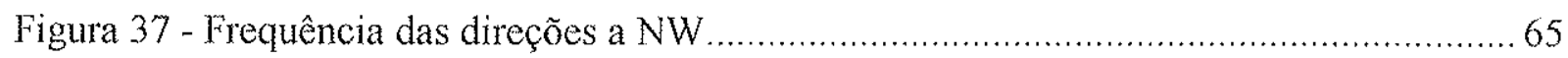

Figura 38 - Correlação entre o teor de cloretos e a condutividade elétrica............................ 70

Figura 39 - Frequência dos valores de compostos orgânicos ......................................... 72

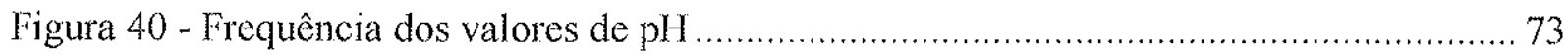

Figura 41 .. Frequência dos valores de ferro total nas análises de água.............................. 75

Figura 42 - Frequência dos valores de dureza ......................................................... 76

Figura 43 - Diagrama de Piper das águas dos poços tubulares ......................................... 79 
ÍNDICE DE TABELAS

N.'TAB. TÍTULO PÁG.

Tabela 1 - Atividade industrial de Joinville ................................................................... 6

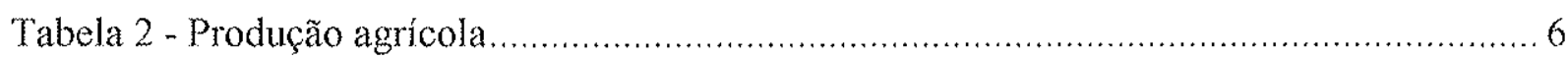

Tabela 3 - Atividade mineral de Joinville ............................................................... 6

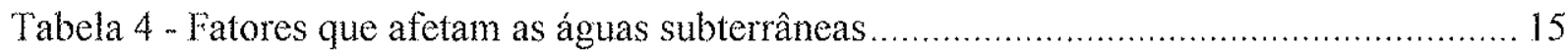

Tabela 5 - Demanda de água projetada até 2030 - Joinville - SC ................................... 16

Tabela 6 - Reservatórios de água de Joinville - SC ....................................................... 17

Tabela 7 - Oferta e déficit de água tratada para consumo humano. Joinville - SC ................ 17

Tabela 8 - Demandas, perdas e déficit do sistema de abastecimento de água ..................... 18

Tabela 9 - Utilização da água subterrânea em Joinville - SC ........................................... 19

Tabela 10 - Descrição das bacias hidrográficas e séries históricas utilizadas ...................... 22

Tabela 11 - Estações utilizadas para determinar o balanço hídrico da bacia do Cachoeira .... 25

Tabela 12 - Alturas de chuvas extremas calculadas nos estudos de simulação de escoamento

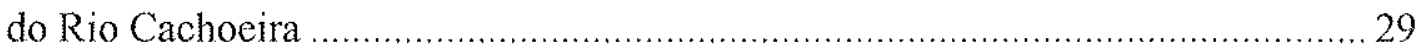

Tabela 13 - Vazões de cheias para a Bacia do Rio Cachoeira ........................................29

Tabela 14 - Volumes de água do balanço hídrico da Bacia do Rio Cachoeira ...................... 31

Tabela 15 - Estações utilizadas para determinar o balanço hídrico da Bacia do Rio Cubatão 33

Tabela 16- Descarga fluvial da Bacia do Rio Cubatão ..................................................... 35

Tabela 17 - Estações utilizadas para determinar o balanço hidrico da Bacia do Rio do Júlio 38

Tabela 18 - Volumes de água do balanço hídrico da Bacia do Rio do Júlio ......................... 40

Tabela 19 - Estações utilizadas para determinar o balanço hídrico da Bacia do Rio Pirai...... 41

Tabela 20 - Volumes de água do balanço hídrico da Bacia do Rio Pirai............................ 43

Tabela 21 - Problemas em revestimentos e filtros .............................................................. 57

Tabela 22 - Relação entre extensão, direção e produtividade dos poços locados sobre

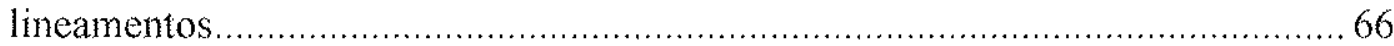

Tabela 23 - Legislação e regulamentação dos valores máximos permitidos para consumo

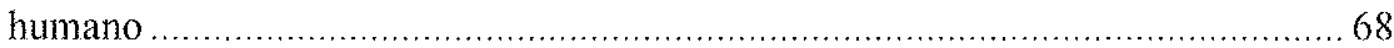

Tabela 24 - Resultado das análises de água dos poços tubulares profundos........................ 69

Tabela 25 - Componentes orgânicos naturais e decorrentes da ação antrópica ..................... 71

Tabela 26 - Características químicas dos componentes inorgânicos do poço nº 09 .............. 77

Tabela 27 - Resultados das análises de água de poços rasos - Pesquisa para coliformes ....... 80 
INDICE DE ANEXOS

N. ANEXO.

Anexo 1 -

Anexo 2 -

Anexo 3 -
TÍTULO

Mapa geológico da área de estudo

Mapa de lineamentos e de áreas favoráveis à locação de poços tubulares profundos

Relação dos poços tubulares profundos 


\section{AGRADECIMENTOS}

Expresso meu sincero agradecimento a todas as pessoas que colaboraram para a realização deste trabalho.

A minha esposa Elaine que sempre incentivou este trabalho e contribuiu positivamente para que fosse concluído.

A meus familiares pelo constante apoio e incentivo.

Ao Instituto de Geociências da Universidade de São Paulo

Ao Orientador Prof. Dr. Aldo da Cunha Rebouças pela orientação, visitas a campo e palestras proferidas para a comunidade Joinvilense e Associação de Geólogos de Joinville.

Ao Prof. Dr. Uriel Duarte pelo intenso apoio e visitas a campo durante a execução do trabalho.

Ao Professor e amigo Dr. Paulo César Soares, da UFPR, o primeiro a incentivar-me no caminho do aperfeiçoamento e pesquisa.

As empresas de perfuração de poços Kupersul e Hidropel que, a pedido da Prefeitura Municipal de Joinville, cederam informações valiosas para o desenvolvimento deste trabalho.

As empresas hoteleiras, industriais e comerciais de Joinville

À colega Mônica Lopes pelas inúmeras discussões técnicas e revisão de textos.

À Fundação Municipal do Meio Ambiente de Joinville - FUNDEMA. À ex-Presidente Eng. Agr. Maria Andreis Cadorin e à ex-Diretora Administrativa Osnilda Bachtöld pelo apoio oferecido para a execução deste trabalho durante os anos de 1995 e 1996. Agradeço ainda ao atual Secretário da Agricultura e Meio Ambiente Dr. Bráulio Barbosa, ao Presidente da Fundema Cel. Silvio Paulo Casali, ao Diretor Administrativo Luiz Lopes e ao Diretor Técnico Décio de Oliveira Cabral pelo total apoio à conclusão deste trabalho.

Aos colegas da FUNDEMA: Adriano Stimamiglio, Fabiana Sehnem, James Schroeder, Jamil El Khaitib, Luiz Camargo, Maria Cristina M. da Silva, Naum A. Santana, pelas diversas discussões técnicas que auxiliaram a elucidar algumas questões aqui desenvolvidas

À Lucélia Kamradt, pela elaboração dos mapas, e à Sérgio F. G. Diniz pela arte final.

Às estagiárias da FUNDEMA Márcia, Sandra, Rosa, Andréa e Alessandra pelas saídas a campo para coleta de dados.

Ao CNPq (processo 830118/96-9) pelo apoio financeiro recebido durante o último ano, o que ajudou a concretizar este trabalho. 


\section{RESUMO}

As águas subterrâneas são nossas reservas mais importantes e representam 97\% da água doce disponivel no mundo.

Joinville é uma cidade em que a precipitação pluviométrica é uma das mais altas do País, em torno de $2.000 \mathrm{~mm} / \mathrm{ano}$. A média anual de ocorrência de chuvas está em torno de 200 dias.

Apesar deste aporte hídrico, a distribuição de água apresenta sérios problemas, e o racionamento ou a falta de água, ainda é uma constante no dia a dia dos habitantes da cidade de Joinville.

Na região as águas subterrâneas estão acumuladas no Aqüifero Fraturado, representado geologicamente por Rochas do Escudo Catarinense, onde o manto de intemperismo atinge em média $40 \mathrm{~m}$ de espessura.

Este aqüífero está compartimentado em duas direções principais N30-40E e N20-30W.

A produtividade dos poços bem locados está em torno de 10 metros cúbicos por hora.

A recarga da água estocada no aqǘfero fraturado atualmente alcança aproximadamente 31 milhões de $\mathrm{m}^{3}$ por ano. A explotação atual de água subterrânea atinge aproximadamente 3 milhões de metros cúbicos por ano o que representa $10 \%$ da recarga. Para a Bacia do Rio Cubatão a recarga estimada chega a 325 milhões de metros cúbicos de água por ano.

Com relação a qualidade da água, as análises realizadas pelo Instituto Tecnológico do Paraná - TECPAR, mostram que as águas subterrâneas de Joinville podem ser localmente definidas como águas alcalinas bicarbonatadas, e ainda não existem problemas de contaminação sanitária.

Este aqüífero é uma nova alternativa complementar ao recurso hídrico superficial. É estrategicamente a maior reserva de água potável da cidade e representa uma excelente opção, haja visto que seus mananciais encontram-se relativamente melhor protegidos dos efeitos da poluição. Por estas características poderá ser a futura fonte complementar de água para a coletividade Joinvilense, se forem mantidas as atuais condições de proteção das suas áreas de recarga. 


\section{ABSTRACT}

The groundwater are the most important reserves and represents $97 \%$ of the fresh water in the world.

The increasing necessity of good quality water is, and will be, the reason for a large number of studies and investments.

The city of Joinville is located northeastern of the state of Santa Catarina horing the geografic coordenates $26^{\circ} 18^{\prime} 05^{\prime \prime}$ South Latitude and $48^{\circ} 50^{\prime} 38^{\prime \prime}$ Longitude West of Greenwich Meridian.

The local pluvial precipitation is one of the highest in Brazil, about 2,000 mm/year. The annual rain precipitation distribution is about 200 days.

In spite of such water surplus its irregular distribution presents serious problems and the lack of, and rationing of water are still a constant nowadays among the city's population.

In its region the groundwater is situated in the fissured rock zones, geologicaly represented by rocks, of Escudo Catarinense, where the weathered zones reaches at about $40 \mathrm{~m}$ length

Such aquifer is located in fractured zones into two main directions: $\mathrm{N} 30^{\circ}-40^{\circ} \mathrm{E}$ and $\mathrm{N} 20^{\circ}$ $30^{\circ} \mathrm{W}$.

The well production is around $1,0-3,0 \mathrm{~m}^{3} / \mathrm{h}$, due to the lack of criterious for its location. This amount could be $10 \mathrm{~m}^{3} / \mathrm{h}$ if improved hydrogeological studies.

The amount of water utilized from the fissured aquiferous reaches approximately $3.000 .000 \mathrm{~m}^{3} /$ year.

With relation to the water quality, the analyses made by the Parana Tecnological Institute (Instituto Tecnológico do Paraná - TECPAR) shows that Joinville's groundwater can be defined as a mineral water and there's no problems of organic contamination yet.

There are no doubts that the aquifer is a needed alternative to the Rivers Cubatão and Piraí. Its is strategically the largest reserve of potable water for the city and represents an excellent option, taking into consideration that this option is the one most protected from the effects of the polution. 


\section{1. - INTRODUÇÃO}

\section{1 - Considerações sobre a área de estudo}

A cidade de Joinville é atualmente o maior centro industrial e a mais populosa cidade do Estado de Santa Catarina.

Como em outras cidades que, a exemplo de Joinville também estão em franco desenvolvimento, a utilização dos recursos hídricos apresenta tendência de crescimento a cada ano, e de acordo com o plano diretor de abastecimento de água e esgotamento sanitário de Joinville de 1994, este crescimento é de aproximadamente $4 \%$ ao ano.

Em linhas gerais a utilização dos recursos hídricos do município estão assim direcionados: os mananciais superficiais, in natura, estão destinados principalmente para a agricultura e após tratamento, para consumo pela população. Por sua vez, os mananciais subterrâneos são, na sua grande maioria, utilizados pelo setor industrial e turístico.

A busca efetiva pela utilização dos mananciais subterrâneos por empresas, data de $1970 \mathrm{e}$ sempre esteve associada à necessidade de água no processo industrial, consumo interno e principalmente à diminuição de custos operacionais e financeiros.

Apesar do município apresentar um grande número de poços tubulares profundos, a divulgação das suas características ainda encontra resistência em algumas empresas perfuradoras que se acham no direito de mantê-las como trunfos de informação para o mercado.

O balanço hídrico, que será descrito neste trabalho, mostra que apenas um pequeno percentual do potencial hidrogeológico de Joinville está sendo atualmente utilizado. $O$ conhecimento desta informação, poderá fomentar locações mais corretas de poços e uma maximização deste recurso, influenciando positivamente nas tomadas de decisões a respeito de uso do território quando da instalação de novas indústrias ou novos centros de desenvolvimento urbano.

A preocupação com o gerenciamento e proteção dos recursos hídricos abrange as três esferas governamentais. A nível federal a lei 9.433 de Janeiro de 1997 instituiu a política nacional de gerenciamento de recursos hídricos. A lei estadual de Santa Catarina, número 9.748 de 30/11/94 trata da política estadual de recursos hídricos, e a nível municipal a lei 
complementar n. ${ }^{\circ} 029$ de 14/06/1996 instituiu o Código Municipal do Meio Ambiente. A partir da aprovação desta lei municipal, a FUNDEMA - Fundação Municipal do Meio Ambiente recebeu a delegação de cadastrar as informações pertinentes ao município de Joinville, bem como analisar projetos de novos poços, controlar os serviços referentes a água subterrânea, fiscalizar, monitorar, disciplinar e outorgar o uso das águas subterrâneas, dentro dos preceitos das três legislações..

1.2 - Considerações sobre o estudo desenvolvido

\subsection{1 - Objetivos}

Os objetivos a serem alcançados neste trabalho estão definidos nos itens que seguem abaixo:

- Cadastrar os poços tubulares profundos em forma de Banco de Dados.

- Realizar análise hidrogeológica dos poços cadastrados a partir de informações bibliográficas e informações do cadastro (profundidades, espessuras do manto de intemperismo, entradas de água, vazões e aspectos construtivos dos poços).

- Realizar análise estrutural do aqüífero fraturado

- Realizar balanço hídrico a partir dos dados coletados das estações pluviométricas e fluviométricas.

- Gerar um mapa dos lineamentos fotointerpretados de parte da área urbana em escala $1: 50.000$

- Indicar áreas mais promissoras para locação de poços para produção de água subterrânea em Joinville. 


\subsection{2 - Metodologia aplicada}

A metodologia aplicada para o desenvolvimento desta dissertação envolveu as seguintes açôes:

- Levantamentos bibliográficos

- Trabalhos de campo e levantamento geológico-estrutural,

- Cadastramento de poços e criação de um banco de dados em formato Access.

- Análise das informações e processamento estatístico,

- Interpretação dos resultados e discussões técnicas,

- Análise e interpretação de fotos aéreas e imagens de satélite,

- Correlações, estudos locais e confecção de textos e mapas. 


\section{2.- ÁREA DE ESTUDO}

\section{1 - Localização}

O município de Joinville localiza-se na região nordeste do Estado de Santa Catarina (figura 1) a $172 \mathrm{Km}$ da capital do Estado, Florianópolis. A cidade tem como coordenadas geográficas: $26^{\circ} 18^{\prime} 05^{\prime \prime}$ de Latitude Sul e $48^{\circ} 50^{\prime} 38^{\prime \prime}$ de Longitude a Oeste de Greenwich (PMJ, 1995)

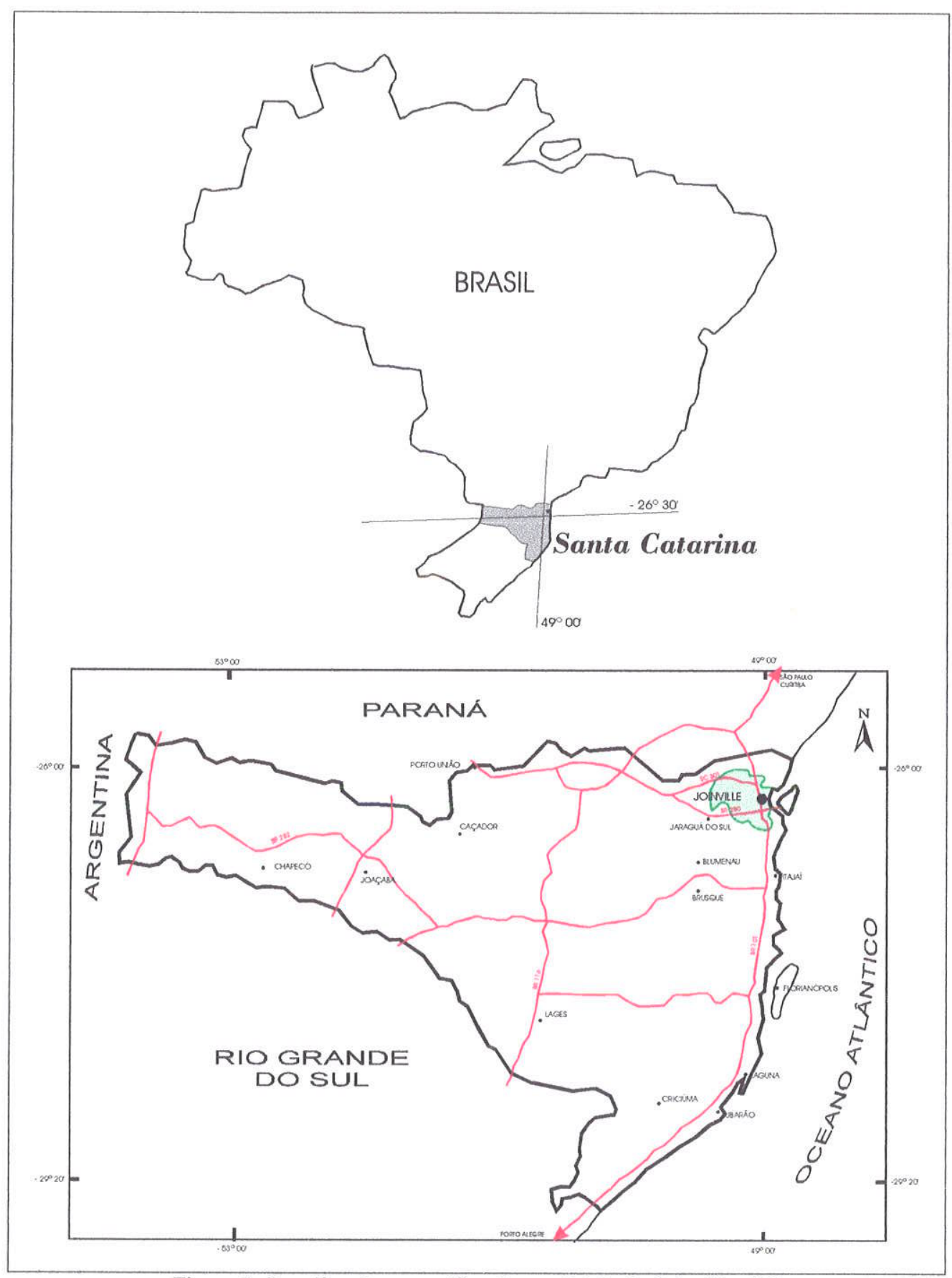

Figura 1: Localização geográfica do município de Joinville - SC 
A área territorial do município é de $1.183 \mathrm{~km}^{2}$, sendo dividida em $347,2 \mathrm{~km}^{2}$ de zona urbana $(29,35 \%)$ e $835,8 \mathrm{~km}^{2}$ de zona rural ( 70,65\%). O município ocupa uma estreita faixa de terra que se estende desde o litoral, passando pela planície litorânea e atinge as escarpas da Serra do Mar, até o Planalto Ocidental.

A leste, encontra-se a Baía de Babitonga, importante formação de águas marinhas interiores, com área de aproximadamente $100 \mathrm{~km}^{2}$. Neste setor existe o maior maciço de manguezais do Estado de Santa Catarina, importante ecossistema costeiro que atua, também, como barreira física à expansão da cidade, neste sentido. Na faixa central, caracterizada como uma planície costeira, está instalada a cidade, às margens da Baía de Babitonga. A oeste, encontra-se as áreas tradicionalmente agrícolas. Neste sentido, encontra-se a segunda barreira física para a expansão da ocupação humana: a Serra do Mar, onde destaca-se uma grande faixa de Mata Atlântica, formando um dos maiores maciços deste importante ecossistema.

A área de estudo abrange parte do município de Joinville. Define um retângulo que está limitado pelos paralelos $26^{\circ} 13^{\prime}$ e $26^{\circ} 24^{\prime}$ de Latitude Sul e os meridianos $48^{\circ} 45^{\prime}$ e $48^{\circ} 54^{\prime}$ de Longitude Oeste, cobrindo uma extensão de aproximadamente $341 \mathrm{Km}^{2}$ (Figura 2).

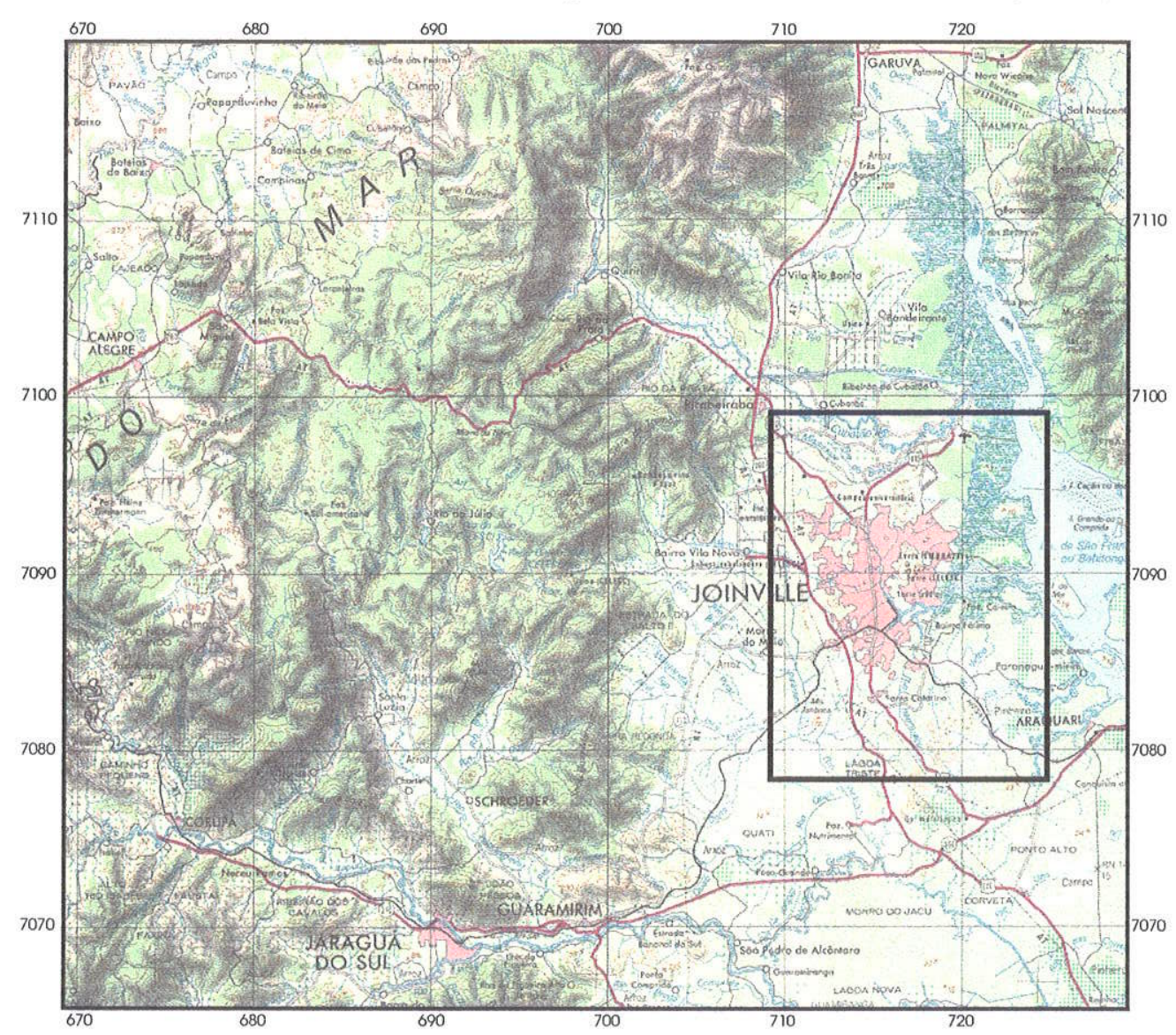

Figura 2 - Localização da área de estudo. 


\section{2-Características sócio-econômicas}

De acordo com os dados da Fundação Instituto de Pesquisa e Planejamento Urbano de Joinville - IPPUJ a população de Joinville em 1996 (projeção) alcançava 426.500 habitantes sendo 411.700 habitantes na zona urbana e 14.800 habitantes na zona rural.

As atividades sócio econômicas mais importantes da cidade são as industriais, agrícolas e minerárias.

A diversidade na indústria está listada na tabela 1 e mostra os seguintes segmentos:

Tabela 1- Atividade industrial de Joinville (empresas com mais de 300 empregados. Fonte PM. 1995)

\begin{tabular}{c|c}
\hline TIPO DE PRODUCAO & NUMERODE EMPRESAS \\
\hline Mecânica/Metalurgia & 13 \\
\hline Têxtil/Confeções & 10 \\
\hline Outras & 09 \\
\hline TOTAL & 32 \\
\hline
\end{tabular}

Joinville apresenta área agricultável de 20.000 ha e conta com 1715 produtores (PMJ, 1995). As atividades agrícolas de Joinville tem como característica fundamental a pequena propriedade, de estrutura familiar e produção de subsistência. As principais culturas desenvolvidas estão listadas na tabela 2.

Tabela 2 - Producão agrícola (Fonte: PMJ 1995)

\begin{tabular}{c|c|c}
\hline CULTURA & AREA (ha) & PRODUCAO (t) \\
\hline Arrozlrigado & 2.540 & 15.240 \\
\hline Mandioca & 263 & 6.049 \\
\hline Cana de Açucar & 139 & $8.20 \mathrm{I}$ \\
\hline Hortalicas & 505 & 41.000 \\
\hline
\end{tabular}

Outra prática que está sendo largamente desenvolvida é o plantio de hortaliças, e culturas permanentes como a bananicultura e o manejo de Pinus e Eucalipto. Na Pecuária, Joinville tem destaque na produção de leite e suinocultura. Atividades como Indústria Caseira e Piscicultura também estão em franco desenvolvimento.

As atividades minerárias que ocorrem em Joinville estão voltadas $99 \%$ para a construção civil de uso imediato e encontram-se listadas na tabela 3 :

Tabela 3 - Atividade mineral de Joinville (Fonte: Baggio 1996)

\begin{tabular}{|c|c|c|}
\hline BEM MINERAL & LAVRA E BENEFICIAM & DESTINA-SE \\
\hline Areja & $\begin{array}{c}\text { Cavas no leito dos rios próximo à Fo\% } \\
\text { Estocagem }\end{array}$ & $\begin{array}{l}\text { Constr, Civil (uso imediato) Ind de } \\
\text { Fundição. }\end{array}$ \\
\hline Argila & $\begin{array}{c}\text { Manto de intemperismo de coloração } \\
\text { ocre. }\end{array}$ & $\begin{array}{l}\text { Principalmente aterro e a fabricação } \\
\text { de telhas e tijolos. }\end{array}$ \\
\hline Caulin & $\begin{array}{l}\text { Planalto Ocidental. desmonte mecânico } \\
\text { do Gnaisse alterado. }\end{array}$ & Para a indústria cerâmica da região. \\
\hline Gnaisse & $\begin{array}{l}\text { Pedreiras. Desmonte com uso de } \\
\text { explosivos. Britagem. }\end{array}$ & Construção civil. \\
\hline $\begin{array}{l}\text { Seixos Rolados (granito, gnaisse, } \\
\text { guarizito, anfibolitos c outros) }\end{array}$ & $\begin{array}{l}\text { Ao longo das Bacias hidrográficas da } \\
\text { vertente leste da Serra do Mar. }\end{array}$ & $\begin{array}{l}\text { Const civil (após britagem) rocha } \\
\text { onnamental de fachadas de casas. }\end{array}$ \\
\hline
\end{tabular}




\section{3 - Aspectos fisiográficos}

\subsection{1 - Geomorfologia}

A expressão geomorfológica da região nordeste de Santa Catarina foi determinada pelas características geológicas, hidrográficas e climáticas.

A região caracterizamse pelo relevo acidentado, mesclado com áreas planas próximas ao litoral. Basicamente, existem três unidades morfológicas distintas na região: a Planície Costeira, as Escarpas da Serra do Mar e o Planalto Ocidental (GAPLAN, 1986)

A Planície Costeira forma uma faixa relativamente estreita entre as encostas da Serra do Mar e a Baía de Babitonga. Nesta área, as altitudes médias não ultrapassam 10 metros, podendo ultrapassar os 50 metros nas áreas mais próximas às encostas da Serra. Estas planícies foram formadas pelos sedimentos oriundos dos processos erosivos da Serra e por depósito de material resultante da dinâmica flúviomarinha. São encontrados, ainda, nesta unidade geomorfológica, morros isolados que podem atingir os 200 metros de altitude.

Nas Escarpas da Serra do Mar, o relevo apresenta-se como uma Serra propriamente dita, com vertentes íngremes voltadas para o leste. Há ocorrência de cristas e picos, separados por vales profundos, onde a diferença de altitude atinge os 400 metros. Os pontos mais altos tem altitude média em torno de 900 metros, ultrapassando os 1200 metros nos pontos mais elevados. De uma forma geral, podemos dizer que as encostas voltadas para o leste apresentam uma inclinação superior a $50^{\circ}$.

As principais estruturas geradas pela compartimentação litológica na área urbana de Joinville definiram feições localmente conhecidas como Morros do Itinga, do Guanabara, do Boa Vista, do Iririú, dos Sargentos e Timbé.

As litologias básicas destas feições são gnaisses bandados e quartzitos. Estes últimos formam corpos alongados, lenticulares, encaixados dentro das unidades Pré Cambrianas. Apresentam direção NNW e garantem a sustentação destas elevações.

Quando observadas as imagens de Satélite (escala 1:250.000) observa-se que esta feição geomorfológica é cortada por estruturas em sua grande maioria direcionada a N35-50E e por 
outra grande família de estruturas aproximadamente perpendicular a esta com direções em torno de N20-40W, ambas com mergulho subvertical.

Além destas feições geomorfológicas existem inúmeras pequenas elevações, cuja denominação local é "mar de morros". Esta feição também herdada pelo forte condicionamento estrutural está limitada por estruturas com extensão entre 100 e $1000 \mathrm{~m}$. As direções destas estruturas obedecem o padrão acima descrito.

\subsection{2 - Hidrografia}

O sistema de drenagem natural do município de Joinville faz parte, em sua totalidade, das vertentes do Allântico. A formação geomorfológica da região, associada às condições climáticas e cobertura vegetal interferem positivamente no regime hídrico das bacias hidrográficas, proporcionando ao município um bom potencial hídrico (IBGE 1983).

O sistema hidrográfico do município apresenta sua organização predominantemente na vertente leste da Serra do Mar, cujos rios se caracterizam por pequena extensão e grande vazão.

A hidrografia de Joinville é constituída, basicamente, por cinco bacias principais: rio Cachoeira, rio Cubatão, rio Pirai, rio do Júlio e rio Pirabeiraba. Esta última é a que apresenta a menor interferência antrópica.

A Bacia do Rio Cachoeira, que corta a área urbana da sede do Município no sentido NOSE e deságua na Baia da Babitonga, passando antes pela Lagoa do Saguaçú, possui como principais afluentes os rios Morro Alto, Matias, Jaguarão, Bucarein, Itaum, Itaum-mirim, Santinho e Velho. Esta bacia divide-se em duas sub-bacias de acordo com o seu relevo:

- Bacia do Cachoeira propriamente dita, tendo como limite de jusante a confluência dos Rios Bucarein e Cachoeira, e a montante por morros da Serra do Mar, entremeados por terrenos aluvionares onde está implantada a grande área urbana da cidade.

- Bacia do Estuário do Cachoeira e Lagoa do Saguaçú, de formação basicamente sedimentar, com baixas declividades e bem caracterizada pelo serpenteio dos meandros dos rios e mesmo de braços de mar.

A Bacia do Cachoeira apresenta um perfil similar para todos os seus tributários. Nascentes em cotas entre 20 a $120 \mathrm{~m}$ acima do nível do mar, com fortes declividades, porém de 
pequenas extensões, que seguem para o leito principal que apresenta baixa declividade e por fim em sua porção terminal com declividades irrisórias ou quase nulas que ocasionam o retardo dos deflúvios.

Além destas características, a hidrologia da bacia do Cachoeira é ainda fortemente influenciada pela grande aproximação do oceano que a associa aos regimes de marés e as fortes precipitações pluviométricas.

Com exceção da bacia do Rio Pirabeiraba, que apresenta a mais baixa densidade populacional, as demais bacias serão descritas no capítulo balanço hídrico (item 5).

\section{3 .4 - Vegetação}

A vegetação na região de Joinville pode ser classificada, de uma forma geral, como Floresta Ombrófila Densa (GAPLAN, 1986), também conhecida como Mata Atlântica. Este tipo de vegetação, que assume tipologias diferenciadas, de acordo com as características climáticas e edáficas da região, cobria originalmente quase a totalidade da extensão do municipio.

A Mata Atlântica caracteriza-se pela sua grande biodiversidade, formando uma vegetação densa e exuberante, que atinge altura superior a 30 metros. As copas das árvores maiores tocamse, formando uma camada relativamente uniforme e fechada. No seu interior, formam-se ainda outros estratos, de plantas menores, adaptadas à iluminação difusa. No estrato médio, aparece o palmiteiro (Euterpe edulis), espécie muito comum na floresta, juntamente com um grande número de plantas epífitas como as bromélias e orquídeas.

\subsection{5 - Clima}

A região de Joinville apresenta um clima quente e úmido, não apresentando uma estação seca, sendo classificado como clima mesotérmico, constantemente úmido (Cf) na classificação de Koeppen (GAPLAN, 1986).

A temperatura média anual é de $22^{\circ} \mathrm{C}$, sendo a média das máximas $25,9^{\circ} \mathrm{C}$ e a média das mínimas de $18^{\circ} \mathrm{C}$. 
O índice de precipitação anual é de $1908,9 \mathrm{~mm}$, com média mensal de $159,4 \mathrm{~mm}$, sendo o mês de junho o que apresenta a menor média, com $88,8 \mathrm{~mm}$. Nos meses de dezembro a fevereiro este índice pode ultrapassar $200 \mathrm{~mm} / \mathrm{mês}$.

A umidade relativa do ar é alta, variando em torno dos $77 \%$. Pode-se destacar que no mês de janeiro a umidade do ar é mais baixa e no mês de abril é mais alta.

Devido às características do relevo, existem dois tipos distintos de clima na região, principalmente com relação à temperatura. O planalto ocidental apresenta temperaturas mais baixas e as planícies costeiras temperaturas mais elevadas. 


\section{GEOLOGIA.}

\section{1. - Geologia Regional}

\section{- Embasamento cristalino:}

$\mathrm{Na}$ área de estudo, as rochas predominantes são aquelas pertencentes ao Escudo Catarinense, que é caracterizado por terrenos Arqueanos de evolução muito complexa e afetados por diversos ciclos tectono-orogenéticos e os sedimentos recentes fluviais e marinhos.

Durante a evolução do ciclo Brasiliano (Proterozóico Superior), uma porção dessa área foi totalmente remobilizada, enquanto outra permaneceu estável, comportando-se como área cratônica e mostrando apenas retrabalhamento parcial (SCHOBBENHAUS, 1984)

Os sistemas de falhamento principais apresentam direção NE e NW. As direções principais são N20E-N40E e N45W - N60W e subordinadamente N-S, N85E, N85W.

Os lineamentos funcionaram, ora como falhas de cisalhamento, ora como falhas tensionais, ao longo de diversos ciclos orogênicos. Esses lineamentos foram responsáveis pela formação das fossas tectônicas que abrigam as sequências de cobertura e foram também sítios de ascensão de rochas vulcânicas e granitóides, bem como controlaram as faixas de dobramentos orogenéticos, delineando o arcabouço geológico dos escudos Catarinense e Rio Grandense (SCHOBBENHAUS, Op Cit)

Em Santa Catarina, estes terrenos Pré Cambrianos correspondem ao Cráton Luiz Alves. Este Cráton compreende os Complexos Luiz Alves, Paraiba do Sul e Suite intrusiva Serra do Mar, descritos a seguir:

Complexo Luiz Alves: Formado por rochas metamórficas, principalmente do fácies granulito de composição básica intermediária gerado no Arqueano e Proterozóico inferior.

Complexo Paraíba do Sul: Constitui uma pequena faixa de rochas no extremo nordeste do Estado de Santa Catarina (llha de São Francisco do Sul e Nordeste de Joinville), e estende-se amplamente no leste do Paraná. Este complexo é formado por rochas gnaissicas, granulíticas e cataclásticas geradas no Proterozóico Superior. 
Suite Intrusiva Serra do Mar: Compreende seis corpos intrusivos (Stocks) que ocorrem entre as rochas do Complexo Luiz Alves. Estes são conhecidos pela denominação de Subida, Corupá, Pirai, Dona Francisca, Morro Redondo e Serra Alta.

No município de Joinville predomina a litologia gnaisse granulítico e subordinadamente gnaisse bandado, quartzito, formação ferrifera, anfibolitos e sedimentos recentes (GONÇALVES, 1993).

Estas rochas encontram-se extremamente decompostas formando solos com manto de intemperismo com espessura próxima a $40 \mathrm{~m}$ na zona urbana. Na zonas rural, onde predomina a Serra do Mar, propriamente dita, o manto de alteração não é tão espesso, pois há frequentemente deslizamentos de encostas. Estes eventos formam depósitos de tálus, com espessuras que podem atingir $100 \mathrm{~m}$.

O gnaisse bandado ocorre em associações litológicas, consorciado com intercalações de quartzito, formação ferrifera bandada e anfibolitos.

\section{- Depósitos sedimentares:}

Os sedimentos recentes que ocorrem em escala regional são de origem fluvial continental e marinha. Os sedimentos de origem marinha estão presentes na área de influência de maré e possuem considerável quantidade de matéria orgânica. Os sedimentos de origem fluvial e continental, são aqueles que foram desagregados da Serra do Mar, transportados pela ação da água e depositados ao longo dos talvegues de drenagem. Estes depósitos estão representados por matacões, seixos, areias, argilas e siltes, condicionados às bacias hidrográficas.

\section{2 - Análise da geologia estrutural}

GONÇALVES (1993) definiu duas fases de deformação das rochas. A mais antiga deu origem a dobras com atitude principal para EW/Subvertical, enquanto que a fase de deformação mais recente tem atifude NS/subvertical e eixo subhorizontal com direção $\mathrm{EW}$.

CUBATÃO DRAGAGENS (1996), definiu três sistemas de falhamentos e fraturamentos principais: N20-40W - Subvertical para SW, NO-20E - Subvertical para SE (sentido regional principal) e N70-90E - Vertical 
Medidas de estruturas levantadas em campo demonstram que a orientação preferencial é de N20-30W, com mergulho variando de 65-85SW. Mostra-se ainda um sistema estruturado a N20-30E, com mergulhos subverticalizados.

\section{3 - Geologia local}

A área central do município de Joinville é geologicamente caracterizada por depósitos do Quaternário, representados pelas areias e argilas ao longo do Rio Cachoeira. Estes depósitos jazem sobre litologias do Escudo Catarinense representadas principalmente por gnaisses, quartzitos e formações ferriferas bandadas. Estas duas últimas litologias afloram nos morros do Boa Vista, Iririú entre outros (anexo 1). A espessura do manto de intemperismo nestes locais atinge aré 60 (sessenta) metros.

O manto de alteração das rochas do Escudo geológico apresenta, principalmente, associações de argilo-minerais e minerais micáceos hidratáveis (regolito). Quando associado com minerais granulares de quartzo, oriundos de quartzitos ou da desagregação de veios mineralizados, este regolito torna-se altamente friável e, portanto, facilmente transportado pela água. Tais processos aumentam sensivelmente quando o solo não apresenta cobertura vegetal ou há intensa movimentação de terra por terraplenagem ou mineração.

Os depósitos coluvio-eluvionares são de expressão mais restrita e foram formados basicamente a partir da alteração das unidades litológicas transportadas pela ação gravitacional que rege as fases de dissecação de encostas. Estão situados, geralmente, nas encosta dos morros e foram gerados no Quaternário (periodo em que houve transporte de solos e rochas com deposição no sopé da encosta). Caracterizam-se pela grande diversidade litológica, presença de matacões de rochas, tanto em superfície como em subsuperficie (conforme verificado no campo e nas sondagens). Compõem-se principalmente de fragmentos de rochas gnaissicas e quartzíticas com perfil de alteração síltico argiloso de coloração acinzentada, avermelhada e amarronada de grande plasticidade e fragmentos de quartzo dispersos.

A composição mineralógica destes depósitos é basicamente aquela pertinente ao grupo das micas, anfibólios, feldspatos e subordinadamente quartzo. A decomposição físico química destes minerais gerou coluvios - eluvios onde localmente podem ser observadas estruturas primárias da rocha e lineamentos de minerais de quartzo (BAGGIO, 1995). 


\section{4. - RECURSOS HÍDRICOS DO MUNICÍPIO.}

\section{1 - Consideraçōes gerais}

A água apresenta-se em constante transformação. Chuva, evaporação, infiltração, entre tantos estados possíveis. O conjunto deles forma um sistema fechado e equilibrado em termos globais e temporais que recebe o nome de ciclo hidrológico.

Em Santa Catarina, a dependência do homem com a água (transporte e dessedentação) estabeleceu o desenvolvimento de cidades ao longo dos rios, como é o caso de Joinville, Blumenau, Gaspar, Caçador, Joaçaba e inúmeras outras cidades. Devido a esta característica cultural, ainda hoje, os rios são as fontes de abastecimento mais utilizadas no Estado.

Por outro lado, é sabido que a maior e principal fonte de água para nosso consumo está no subsolo. As águas subterrâneas respondem por $97 \%$ do volume total de água doce do planeta. Tratam-se de reservas estratégicas, das quais depende a perpetuação de nossa espécie.

O município de Joinville destaca-se no cenário catarinense como cidade essencialmente industrial, com agricultura de subsistência (item 2.2), extração de materiais geológicos para a indústria cerâmica e construção civil em franco desenvolvimento, e um crescimento urbano explosivo, onde proliferam os loteamentos (legais e irregulares). Predomina a forma caótica de uso e a ocupação do território comprometendo a qualidade das águas dos mananciais de superfície. Este crescimento acelerado é diretamente proporcional à geraçâio de problemas.

Com relação às águas subterrâneas, estes impactos negativos refletem-se na quantidade e na qualidade da água, através da redução das recargas naturais do sistema, da indução de poluição a partir de vazamentos de tancagens de combustíveis, do lançamento de esgotos e efluentes industriais no solo, acidentes de transporte de produtos perigosos, disposição inadequada de resíduos domésticos e industriais e aplicação de agrotóxicos, entre outros.

ALBUQUERQUE FLLHO (1995) discutindo os problemas envolvendo águas subterrâneas e o uso e ocupação do território, destaca que ações simples adotadas previamente podem minimizar significativamente os efeitos provocados tanto sobre a quantidade como na qualidade das águas subterrâneas. A tabela 4 destaca os fatores correlatos à área do presente estudo. 
Tabela 4: Fatores que afetam as águas subterrâneas.(Fonte Albuquerque Filho 1995 - modificado).

\begin{tabular}{|c|c|c|}
\hline $\begin{aligned} \text { 1. ORIGEM } \\
\text { 2. } \\
\text { CAUSA }\end{aligned}$ & ALTERAÇÓES NO AQUUTFERO & REPERCUSSÃO NO USO E OCUPACÁOO DO MEIO \\
\hline $\begin{array}{l}\text { 1. Bombeamento } \\
\text { 2. Super } \\
\text { explozação do } \\
\text { aqüifero }\end{array}$ & $\begin{array}{l}\text { - Rebaixamento do NE, } \\
\text { - diminuiçáo da espessura saturada } \\
\text { - induçęão do avanço de cunhas saliuas } \\
\text { (aquíferos costeiros) }\end{array}$ & $\begin{array}{l}\text { - Restrição de usos da água subterrânea, } \\
\text { - esgotamento do manancial, } \\
\text { - danificação ou destruçẫo de construções . }\end{array}$ \\
\hline $\begin{array}{l}\text { 1. Mincração } \\
\text { 2. Implantação de } \\
\text { cavas ou túneis } \\
\text { de minerą̧ão }\end{array}$ & $\begin{array}{l}\text { - Rebaixamento do NE, } \\
\text { - Diminuição da espessura saturada } \\
\text { - Diminuição da unidade dos solos }\end{array}$ & $\begin{array}{l}\text { - Aumento da diffculdade de acesso às águas subterrâneas } \\
\text { - Perda de pontos de captação instalados } \\
\text { - Diminuição de volumes disponíveis para abastecimento } \\
\text { - Derda de produtividade em áreas aptas para a agricultura. } \\
\text { - Danificação em construçóes. }\end{array}$ \\
\hline $\begin{array}{l}\text { 1. Obrá civil } \\
\text { 2. Instalação de } \\
\text { reservatórios }\end{array}$ & $\begin{array}{l}\text { - Elevação do nivel de água subterrânea } \\
\text { - Sumento da espessura saturada. } \\
\text { - Salinizaçãa de água en altos topográticos superficiais } \\
\text { - Aumento da vulnerabilidade à contaminação } \\
\text { da água subterrânea } \\
\text { Colapso do solo. }\end{array}$ & $\begin{array}{l}\text { - Restrição dos usos da água subterrânca. } \\
\text { - Perda de pontos de captação instalados. } \\
\text { - Saturação diferencial em sub leitos de vias. } \\
\text { - Danificação ou perda de construções. } \\
\text { - Geração, reativação ou aceleração de processos crosivos } \\
\text { lineares. } \\
\text { umectação ou saturação de sepulturas em cemitérios. }\end{array}$ \\
\hline $\begin{array}{l}\text { 1. Obra civil } \\
\text { 2. Implantação de } \\
\text { estruturas } \\
\text { subuterrâneas } \\
\text { impermeáveis }\end{array}$ & $\begin{array}{l}\text { - Elevaçâo do nivel de água subterrânea } \\
\text { - Aumento da espessura saturada } \\
\text { - Formação de lluxos preferenciais para a } \\
\text { água subterrânea } \\
\text { - Erosão inierna do solo }\end{array}$ & $\begin{array}{l}\text { - Danificação ou perda de construções } \\
\text { - Contaminação de reservatórios de ágıa subterrânea }\end{array}$ \\
\hline $\begin{array}{l}\text { 1. Domestica } \\
\text { 2. Lancamento de } \\
\text { águas servidas } \\
\text { dirctamente } \\
\text { sobre o solo }\end{array}$ & $\begin{array}{l}\text { - Elevação do nível de água subterrânea } \\
\text { - Ceração de aqǘfero suspenso } \\
\text { - Cesestabilização de taludes adjacentes } \\
\text { - conso do solo } \\
\text { - coninação das águas subterrâneas }\end{array}$ & $\begin{array}{l}\text { - Restrição do uso da água subterrânea. } \\
\text { - Poenças de veiculação hidrica. }\end{array}$ \\
\hline $\begin{array}{l}\text { 1. Doméstica } \\
\text { 2. Latrina / poço } \\
\text { negro/fossa. }\end{array}$ & - Contaminaçấo da água subterrânea & $\begin{array}{l}\text { - Perda de pontos de captação instalados } \\
\text { - Restrição de usos da água subterrânea } \\
\text { - Redução da disponibilidade de água para o } \\
\text { abastecimento } \\
\text { - Doenças de veiculação hídrica }\end{array}$ \\
\hline $\begin{array}{l}\text { 1. Urbanização } \\
\text { 2. Lixões e aterros } \\
\text { sanitários }\end{array}$ & $\begin{array}{l}\text { - Formação de chormme } \\
\text { - Migração dos lixiviados para o aqǘfero } \\
\text { - instabilizaçấo geotécnica eñ lixões }\end{array}$ & $\begin{array}{l}\text { - Perda de pontos de captação instalados } \\
\text { - Restrição de usos da água subterrânea } \\
\text { - Redução da disponibilidade de água para o } \\
\text { abastecimento } \\
\text { - Doenças de veiculação hídrica }\end{array}$ \\
\hline $\begin{array}{l}\text { 1. Industrial } \\
\text { 2. Lagoas de } \\
\text { estabilização }\end{array}$ & $\begin{array}{l}\text { - Migração de água contaminada. } \\
\text { - Contaminação do solo. } \\
\text { - Elevaçầo do nivel de água do aqüifero } \\
\text { abaixo da lagoa. }\end{array}$ & $\begin{array}{l}\text { Perda de pontos de captação instalados } \\
\text { - Restrição de usos da água subterrânca } \\
\text { - Doenças de veiculação lídrica }\end{array}$ \\
\hline $\begin{array}{l}\text { 1. Agricultura } \\
\text { 2. Jrrigação com } \\
\text { água scrvida }\end{array}$ & $\begin{array}{l}\text { - Geração de aqüífero suspenso ou aumento } \\
\text { da espessura saturada } \\
\text { - Aparecimento de surgências de água } \\
\text { - Contaminação da água sublemânea }\end{array}$ & $\begin{array}{l}\text { - Perda de pontos de captação instalados } \\
\text { - Restrição de usos da água subterrânea } \\
\text { - Reduçâo da disponibilidade đe água para o } \\
\text { abastecimento } \\
\text { - Doenças de veiculação hídrica }\end{array}$ \\
\hline $\begin{array}{l}\text { 1. Urbanização } \\
\text { 2. Vazamento de } \\
\text { gasolina em } \\
\text { postos de } \\
\text { serviços }\end{array}$ & $\begin{array}{l}\text { Contaminação local e regional do solo e da } \\
\text { água subterânea }\end{array}$ & $\begin{array}{l}\text { - Perda de pontos de caplação instalados } \\
\text { - Restricãa de usos da água subterrânea } \\
\text { - Riscos de incêndios e explosôes }\end{array}$ \\
\hline $\begin{array}{l}\text { 1. Industrial } \\
\text { 2. Poços de } \\
\text { infilltração }\end{array}$ & $\begin{array}{l}\text { Contaminação da água subterrânea na árca } \\
\text { de descarga }\end{array}$ & $\begin{array}{l}\text { - Perda de pontos de captação instalados } \\
\text { - Restriçấo de usos da água subterrânea } \\
\text { - Doenças de veiculação hidrica }\end{array}$ \\
\hline $\begin{array}{l}\text { 1. Urbanização } \\
\text { 2. Cemitérios }\end{array}$ & $\begin{array}{l}\text { - Contaminação do solo e das águas } \\
\text { subtertâneas }\end{array}$ & $\begin{array}{l}\text { - Perda de pontos de captação instalados } \\
\text { - Restrição de usos da água subterânea } \\
\text { - Doenças de veiculaçâo hídrica }\end{array}$ \\
\hline
\end{tabular}


4.2 - Utilização atual dos recursos hídricos.

4.2.1 - Sistema de abastecimento de água - CASAN

Em Joinville, os rios Cubatão, Pirai e Motucas suprem a demanda de água para consumo de $95 \%$ da população. A empresa de água e Esgotos é a CASAN - Cia Catarinense de Águas e Saneamento.

A CASAN é uma Sociedade Anônima de Economia Mista, criada pela lei Estadual 4.547 de 31/12/1970 e, em Joinville está à frente dos assuntos de água e esgoto desde 23/06/73, quando firmou convênio com a Prefeitura Municipal de Joinville (Lei Municipal n. ${ }^{\circ}$ 1.284).

Atualmente a CASAN opera com três estaçôes de tratamento de água (ETA): a ETA Cubatão, que produz $2700 \mathrm{~m}^{3} / \mathrm{h}$, Pirai $1620 \mathrm{~m}^{3} / \mathrm{h}$ e Motucas $65 \mathrm{~m}^{3} / \mathrm{h}$, num total de $4385 \mathrm{~m}^{3} / \mathrm{h}$. A rede de distribuição de água tem uma extensão de $1660 \mathrm{Km}$ e uma rede de adutoras com 55 $\mathrm{Km}$.

Em 1994, a CASAN contratou uma consultoria para desenvolver o plano diretor de abastecimento de água e esgotamento sanitário de Joinville. Aquele estudo mostrou que a demanda de água projetada até 2030 para a cidade de Joinville apresenta em média um crescimento anual de $4 \%$. A tabela 5 mostra o resultado daquela pesquisa.

\begin{tabular}{c|c|c|c} 
Tabela 5: Demanda de água projetada até 2030 - Joinville - SC. \\
\hline ANO & População total & Populą̧̃̃o Abastecida & $\begin{array}{c}\text { Demanda média } \\
\left(\mathrm{m}^{3} / \mathrm{h}\right)\end{array}$ \\
\hline 1997 & 418.316 & 397.400 & $2590)^{*}$ \\
\hline 2000 & 459.773 & 436.784 & 5058 \\
\hline 2005 & 542.121 & 515.015 & 6718 \\
\hline 2010 & 639.217 & 607.256 & 9450 \\
\hline 2015 & 761.025 & 722.974 & 11297 \\
\hline 2020 & 906.044 & 860.742 & 13450 \\
\hline 2025 & 1.089 .155 & 1.031 .697 & 16168 \\
\hline 2030 & 1.309 .273 & 1.243 .809 & 19453 \\
\hline Fonte: Ecológica (1994) - * média atual CASAN & &
\end{tabular}

A produção de água atual, está dentro das necessidade do município. Porém os dados oficiais da CASAN (julho/97) apontam perdas no sistema da ordem de $48 \%$ o que representa $2105 \mathrm{~m}^{3} / \mathrm{h}$ que são eliminados por problemas financeiros e físicos (tratamento, rede de distribuição e problemas de cunho operacional). Preocupada com estes números a CASAN deflagrou um plano estratégico que reduzirá estas perdas em uma primeira etapa para $30 \%$ e depois $25 \%$. Com base nestes dados o déficit de água alcança $310 \mathrm{~m}^{3} / \mathrm{h}$. Porém os índices 
médios de perdas em 1996 atingiram 57\%, e representaram $436 \mathrm{~m}^{3} / \mathrm{h}$. Atualmente este problema está sendo contornado pelo gerenciamento dos onze reservatórios de água (Tabela 6 ) que possuem capacidade total para reservar $36.630 \mathrm{~m}^{3}$ de água.

Tabela 6: Reservatórios de água de Joinville - SC

\begin{tabular}{|c|c|c|c|}
\hline RESERVATORIO & LOCALIZAÇAOO & COTA & CAPACIDADE \\
\hline R-Alpha & Rua Pres de Gaulle - Alto da Rua XV & $74.60 m$ & $1220 \mathrm{~m}^{3}$ \\
\hline R-Zero & $\begin{array}{l}\text { Rua XV de Novembro - Fundos Cervej. } \\
\text { Antarctica }\end{array}$ & $50.00 \mathrm{~m}$ & $4000 \mathrm{~m}^{3}$ \\
\hline Rm01 & $\begin{array}{l}\text { Rua Papa João XXIll - Atrás Hospital } \\
\text { Regional - Boa Vista. }\end{array}$ & $48.25 \mathrm{~m}$ & $2980 \mathrm{~m}^{3}$ \\
\hline R.02 & Rua Caixa D'água (Bairro Santo Antônio) & $51.60 \mathrm{~m}$ & $2540 \mathrm{~m}^{3}$ \\
\hline R-03 & Rua Fritz Alt - Atrás do 1.DP - B. Vista & $56.80 \mathrm{~m}$ & $3400 \mathrm{~m}^{3}$ \\
\hline R-04 & $\begin{array}{l}\text { Rua Belarmino Garcia - Lateral Mons. } \\
\text { Gercino - B. Itaum }\end{array}$ & $61.30 \mathrm{~m}$ & $9540 \mathrm{~m}^{3}$ \\
\hline R-05 & Rua XV novembro (Final) - Vila Nova & $56.00 \mathrm{~m}$ & $250 \mathrm{~m}^{3}$ \\
\hline R-06 & BR 280 - SC - Próx. trevo de Pirabeiraba & $52.00 \mathrm{~m}$ & $700 m^{3}$ \\
\hline $\mathrm{R}-0 \mathrm{~T}$ & $\begin{array}{l}\text { Rua Nelson Brandão - Lateral Rua Tuiuti } \\
-B \text {. Aventureiro }\end{array}$ & $54.00 \mathrm{~m}$ & $5000 \mathrm{~m}^{3}$ \\
\hline $\mathrm{R}-11$ & Rua Polo Sul (Profipo) & $60.50 \mathrm{~m}$ & $3000 \mathrm{~m}^{3}$ \\
\hline $\mathrm{R}-12$ & $\begin{array}{l}\text { Rua Boehmerwaldt (lat. próx. Cadeia } \\
\text { Pública) }\end{array}$ & $44.50 \mathrm{~m}$ & $4000 m^{3}$ \\
\hline
\end{tabular}

A média anual das vazões tratadas é de $5.345 \mathrm{~m}^{3} / \mathrm{h}$. Deste valor são recalcados $5.027 \mathrm{~m}^{3} / \mathrm{h}$ para a rede de distribuição. A diferença entre as vazões tratadas e o volume distribuído $\left(318 \mathrm{~m}^{3} / \mathrm{h}\right)$ é utilizada no processo. A tabela 7 apresenta os valores das perdas, demandas e déficit de água de maio de 1996 a maio de 1997.

Tabela 7: Oferta e déficit de água tratada para consumo humano. Joinville - SC.

\begin{tabular}{|c|c|c|c|c|c|c|}
\hline & $\begin{array}{c}\text { vaxóes } \\
\text { tratadas } \\
\mathrm{m}^{3} / \mathrm{h} \\
\end{array}$ & $\begin{array}{l}\begin{array}{c}\text { vol. } \\
\text { distribuido } \\
\mathrm{m}^{3} / \mathrm{h}\end{array} \\
\end{array}$ & $\begin{array}{c}\text { perdas } \\
(\%)\end{array}$ & $\begin{array}{c}\text { perdas } \\
\mathrm{m}^{3} / \mathrm{h}\end{array}$ & $\begin{array}{c}\text { demandas } \\
\mathrm{m}^{3} / \mathrm{h}\end{array}$ & $\begin{array}{c}\text { déficit } \\
\mathrm{m}^{3} / \mathrm{h}\end{array}$ \\
\hline Mai/96 & 5267 & 4994 & $51.35 \%$ & 2565 & 2915 & 486 \\
\hline Jun/96 & 5224 & 4909 & $50.62 \%$ & 2485 & 2909 & 485 \\
\hline $\mathrm{Jul} / 96$ & 5251 & 4974 & $51.25 \%$ & 2550 & 2910 & 486 \\
\hline $\mathrm{Ago} / 96$ & 5256 & 4941 & $52.15 \%$ & 2577 & 2838 & 474 \\
\hline Set/96 & 5303 & 4979 & $54.52 \%$ & 2715 & 2718 & 454 \\
\hline Out/96 & 5351 & 5020 & $61.02 \%$ & 3063 & 2348 & 391 \\
\hline Nov/96 & 5274 & 4933 & $54.22 \%$ & 2675 & 2710 & 452 \\
\hline $\mathrm{Dez} / 96$ & 5281 & 4913 & $58.50 \%$ & 2874 & 2447 & 408 \\
\hline $\operatorname{Jan} / 97$ & 5707 & 5513 & $62.52 \%$ & 3447 & 2480 & 414 \\
\hline Fev/97 & 5200 & 4811 & $55.82 \%$ & 2686 & 2550 & 425 \\
\hline Mar/97 & 5397 & 5083 & $61.79 \%$ & 3141 & 2330 & 388 \\
\hline $\mathrm{Abr} / 97$ & 5363 & 5055 & $58.72 \%$ & 2968 & 2504 & 417 \\
\hline $\mathrm{mai} / 97$ & 5532 & 5231 & $62.74 \%$ & 3282 & 2339 & 390 \\
\hline MEDIAS & 5345 & 5027 & $56.99 \%$ & 2848 & 2590 & 436 \\
\hline
\end{tabular}

A CASAN está executando um plano de ampliação do sistema de abastecimento de água de Joinville. Estão em construção uma nova tomada de água no rio Cubatão, nova ETA com floculadores e decantadores (para solucionar o problema da turbidez durante as chuvas torrenciais) e outras obras complementares. 
Com base nestas informações foi criada a tabela 8 que prevê a ampliação do sistema, considera as perdas projetadas pela CASAN e por fim os déficit médios até o ano de 2012. A análise desta tabela aponta um déficit mínimo, a curto prazo de $494 \mathrm{~m}^{3} / \mathrm{h}$, para abastecimento de $95 \%$ da população. Para minimizar este problema será avaliado no item 4.2 .2 e 4.3 a possibilidade de utilização do manancial subterrâneo para suprir esta necessidade.

Tabela 8 - Demandas, perdas e déficit do sistema de abastecimento de água (Projecão até 2012).

\begin{tabular}{|c|c|c|c|c|c|c|c|c|}
\hline ano & $\begin{array}{c}\text { população } \\
\text { total } \\
\text { (hab.) }\end{array}$ & $\begin{array}{l}\text { população } \\
\text { abastecida } \\
\text { (hab.) }\end{array}$ & $\begin{array}{c}\text { demanda } \\
\text { média } \\
\mathrm{m}^{3} / \mathrm{h}\end{array}$ & $\begin{array}{c}\text { projeçăo } \\
\text { das vazões } \\
\mathrm{m}^{3} / \mathrm{h}\end{array}$ & $\begin{array}{c}\text { perdas } 1 \\
\text { projetadas } \\
30 \%-\mathrm{ml}^{3} / \mathrm{h}\end{array}$ & $\begin{array}{c}\text { déficit } \\
1 \\
\mathrm{~m}^{3} / \mathrm{h}\end{array}$ & $\begin{array}{l}\text { perdas } 2 \\
\text { projetadas } \\
25 \%-\mathrm{m}^{3} / \mathrm{h}\end{array}$ & $\begin{array}{c}\text { déficit } \\
2 \\
\mathrm{~m}^{3 / / h} \\
\end{array}$ \\
\hline 1999 & 445.516 & 423.240 & 4409 & 5220 & 1566 & 755 & 1305 & 494 \\
\hline 2001 & 475.176 & 451.417 & 4702 & 5652 & 1696 & 746 & 1413 & 463 \\
\hline 2005 & 542.121 & 515.015 & 5365 & 6480 & 1944 & 829 & 1620 & 505 \\
\hline 2012 & 685.407 & 651.137 & 6783 & 8280 & 2484 & 987 & 2070 & 573 \\
\hline
\end{tabular}

Outra análise que deve ser feita sobre os mananciais superficiais de Joinville diz respeito aos problemas originados por fenômenos naturais que estão totalmente fora do controle humano, ou seja as grandes estiagens e as grandes enchentes.

Quando ocorrem períodos de grandes precipitações, a produção de água potável é prejudicada devido à alta turbidez ou pela inundação das estações de tratamento de água. Em Janeiro deste ano, quando foi registrada a ocorrência de enchente, a produção diminuiu em $60 \%$. Já na grande enchente de Fevereiro de 1995 a produção foi totalmente paralisada. Quanto às estiagens a queda na produção pode chegar até $30 \%$ na Estação de tratamento do Rio Pirai (julho/1997).

No que diz respeito às ações desenvolvidas para sanar estes problemas a CASAN está instalando unidades de floculação e decantação nas ETAs Cubatão e Pirai. Esta medida atenuará os problemas de turbidez durante períodos de chuvas intensas, e o sistema continuará abastecendo a cidade normalmente. Persistirá apenas o problema relativo às grandes estiagens na captação do Rio Pirai.

4.2.2 m Sistemas independentes de abastecimento de água subterrânea.

A utilização da água subterrânea em Joinville vem ocorrendo de longa data (no mínimo 1953). Porém somente a partir de 1970, os sistemas de abastecimento independentes apresentaram um crescimento visível (ítem 7.1.3) e sempre estiveram ligados à iniciativa privada, principalmente indústrias, hotéis/motéis e ultimamente condomínios residenciais. 
Os estudos mais aprofundados a respeito de água subterrânea em Joinville são relativamente recentes.

Uma das primeiras informações sobre as águas subterrâneas de Joinville é de Maack (In PLANEPAR, 1973). O autor descreve o perfil estratigráfico de sondagens e aponta $5 \mathrm{~m}^{3} / \mathrm{h}$ como vazão média dos poços da região.

Picker (in PLANEPAR., 1973) descreve as rochas aflorantes da região Serrana, discute a alteração das rochas que atinge em alguns locais até $20 \mathrm{~m}$ de profundidade e tece comentários sobre a geologia estrutural.

GONÇALVES (1993) iniciou as primeiras discussões a respeito de usos de água subterrânea com um cadastro de 57 poços, ademais analisou as condições de uso e ocupação do território e mostrou preocupação com possiveis contaminantes. A referida autora descreve que a utilização de águas subterrâneas para fins industriais em 1992 chegava a $388 \mathrm{~m}^{3} / \mathrm{h}$.

GONÇALVES E DUARTE (1996) desenvolveram pesquisa de cunho geotécnico, analisando poços rasos, e definiram a área de recarga do aqüífero - manto e fraturado. Definiram ainda dois tipos de aqüíferos, o freático, associado à zona saturada do manto de intemperismo e sedimentos (poços rasos) e o aqüúfero fraturado, associado às rochas do Complexo Granulítico (poços tubulares profundos).

A partir do presente estudo constatou-se que além da recarga natural do aqüífero, que será analisada no item balanço hídrico, o sistema de abastecimento de água da CASAN induz uma recarga artificial equivalente às perdas já quantificadas, ou seja $2105 \mathrm{~m}^{3} / \mathrm{h}$ (Volume que provém das Bacias dos rios Pirai e Cubatão, e é induzido em grande parte na Bacia do Rio Cachoeira). No que diz respeito à produção atual, os poços tubulares profundos cadastrados, produzem cerca de $690 \mathrm{~m}^{3} / \mathrm{h}$.

A tabela 9, a seguir mostra a evolução da utilização da água subterrânea em Joinville.

Tabela 9: Utilização da água subterrânea em Joinville - SC

\begin{tabular}{c|c}
\hline Período & Agua Subterrânea utilizada $\left(\mathrm{m}^{3} / \mathrm{h}\right)$ \\
\hline 1993 & 388 \\
\hline 1997 & 690 \\
\hline
\end{tabular}


Como já foi descrito, o déficit do sistema de abastecimento de água a curto prazo será de $494 \mathrm{~m}^{3} / \mathrm{h}$. Este valor representa $72 \%$ da vazão atualmente extraída pela iniciativa privada de poços tubulares profundos.

O anexo 2, mostra áreas onde a perfuração de poços tubulares profundos bem construídos podem apresentar maior probabilidade de êxito para vazões maiores que $10 \mathrm{~m}^{3} / \mathrm{h}$. A partir disso, este déficit pode ser minimizado através da instalação e operação de uma rede de poços tubulares profundos, utilizados exclusivamente para fins de abastecimento público.

\section{3 - Abastecimento de água: soluções e alternativas}

A produção de água, independentemente se for subterrânea ou superficial deve ser ininterrupta e suficiente para prover toda a população e todas as ações por ela desenvolvidas.

Para resolver o problema de falta de água é necessário ter alternativas passíveis de implementação. A alternativa aqui proposta é o sistema de abastecimento público misto. No caso de Joinville, a cidade tem duas opções: $1^{\text {a: }}$ implantação de uma rede de poços tubulares profundos ao longo dos rios Cubatão e Pirai, e $2^{\text {a: }}$ implantação de poços tubulares profundos na zona urbana, distribuídos conforme a necessidade de água local.

A utilização da água subterrânea como complementação dos recursos superficiais, sob a ótica de viabiabilidade física, técnica e econômica é favorável, uma vez que o aqüífero tem potencialidade para preencher a lacuna do déficit no sistema de abastecimento. Poderá ser ainda, a melhor alternativa durante os períodos críticos de estiagem, enchentes ou em casos de acidente rodoviário que envolva uma carga de produtos perigosos, de alta toxicidade na Serra Dona Francisca, domínios do Rio Seco, importante afluente do Rio Cubatão, de onde provém $75 \%$ do abastecimento de Joinville.

A avaliação dos volumes potenciais de água subterrânea para cobrir o déficit será detalhada e quantificada no item 5 .

A iniciativa privada (indústrias e hotéis) produz diariamente $690 \mathrm{~m}^{3} / \mathrm{h}$ (operação do poço em turno de 12 horas). Cada sistema independente tem um investimento inicial de 
aproximadamente U\$12 mil e requer manutenção periódica. O retorno deste investimento é de 18 meses ou menos, conforme o tamanho da empresa e a utilização que faz do manancial.

Com relação à viabilidade social, este trabalho consultou a opinião pública da zona urbana e da zona rural. $O$ questionamento básico envolveu a utilização da água subterrânea. Os resultados mostraram que a população não se opõem a utilização da água subterrânea, pelo contrário. O que mais ficou evidenciado foi a falta de conhecimento dos mananciais subterrâneos e sobretudo, que para a população o que importa é a água na torneira e não de onde ela vem.

A análise da viabilidade financeira e política não faz parte do objetivo desta dissertação, entretanto, deverá ser tratada como prioridade básica dentro do plano de governo municipal e estadual, uma vez que o assunto é de extrema relevância política e social. A vontade política deverá estar comprometida com esta necessidade básica da população, e será refletida no montante dos recursos financeiros que deverão ser buscados para a implantação do sistema de abastecimento misto. 


\section{BALANÇO HÍDRICO}

\section{1 - Considerações gerais}

Joinville apresenta um dos maiores índices pluviométricos do País. Isto se deve às chuvas orográficas ocasionadas pelo resfriamento adiabático gerado pela expansão da massa de ar saturada proveniente do Oceano Atlântico, ao tentar ultrapassar a barreira da Serra do Mar (DT CONSULTORES, 1991).

Conforme os dados pluviométricos do posto da Escola Técnica Tupy (ETT) a precipitação média anual acumulada em Joinville é muito próxima a $2.000 \mathrm{~mm}$, sendo que, nos últimos cinco anos a ocorrência de chuvas atingiu em média 200 dias/ano.

A área de estudo está praticamente inserida na bacia do Rio Cachoeira, porém as demais bacias do município também foram analisadas com o objetivo de definir e quantificar os recursos hídricos a nível macro. Por isso o balanço hídrico aqui proposto setorizou o município em bacias hidrográficas. Foram separadas as Bacias do Rio Cachoeira, Cubatão, Júlio / Itapocuzinho e Pirai.

Para cada bacia foi eleito pelo menos um posto pluviométrico / fluviométrico. A Bacia do Rio Pirabeiraba por apresentar a menor densidade ocupacional não foi incluída neste estudo. A tabela 10 mostra estas bacias e as respectivas séries históricas utilizadas para cada uma, conforme a disponibilidade de informações.

Tabela 10: Descricão das bacias hidrográficas e séries históricas utilizadas

\begin{tabular}{c|c}
\hline BACIA HOROGRAFICA & SERIE MISTÓRICA \\
\hline Rio Cachoeira (Area de estudo) & $1971-1980$ \\
\hline Rio Cubatão & $1950-1972$ \\
\hline Rio do Júlio/ltapocuzinho & $1987-1995$ \\
\hline Rio Pirai & $1977-1985$ \\
\hline
\end{tabular}


A figura 3 mostra a distribuição geográfica das Bacias hidrográficas envolvidas neste estudo e a localização das estações utilizadas.

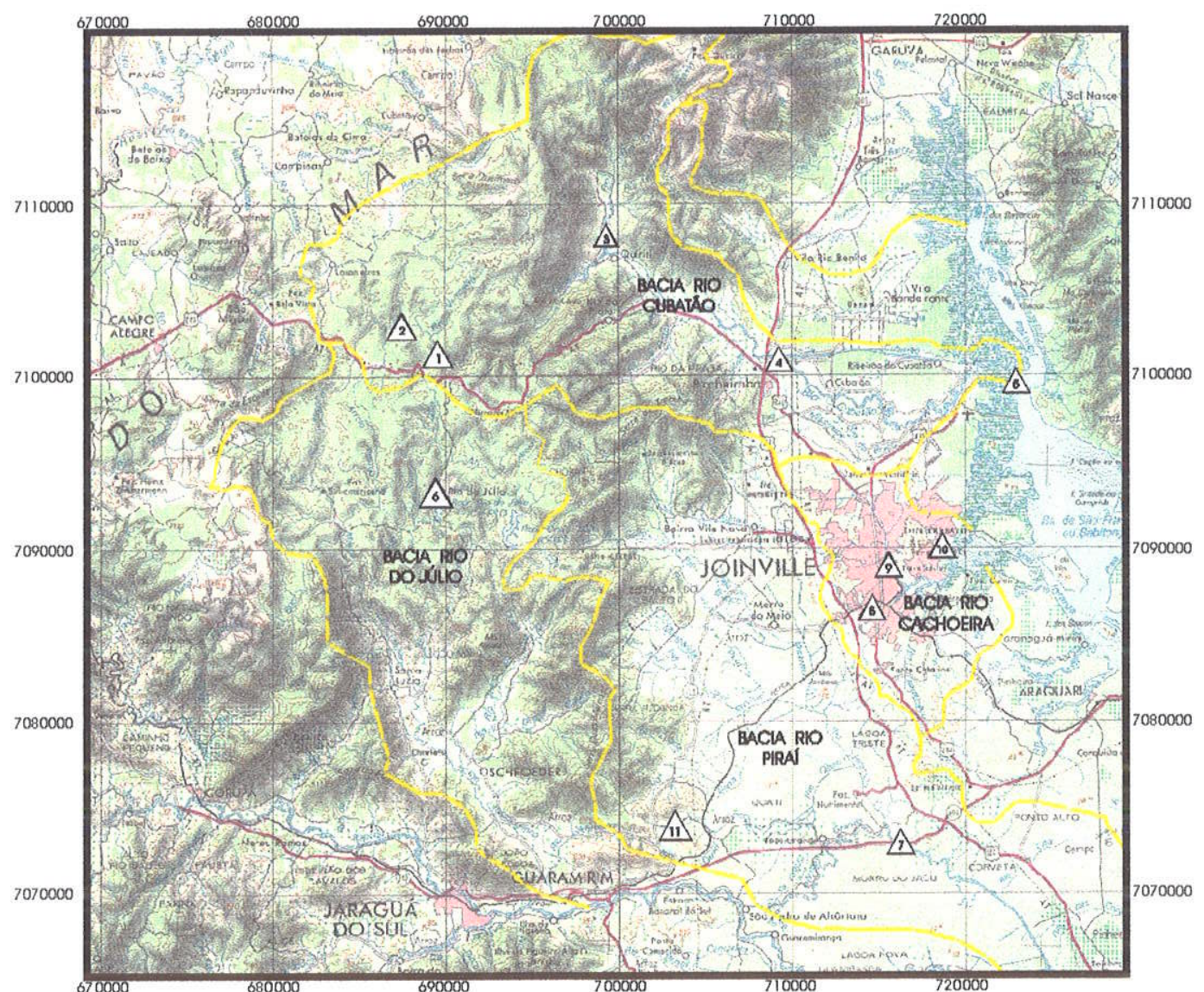

Figura 3 : Localização geográfica das bacias hidrográficas e das estações pluviométricas e fluviométricas. $\Delta 1$ - Salto 1, $\Delta 2$ - Salto 2, $\Delta 3$ - Quiriri,$\Delta 4$ - Barragem, $\Delta 5$ - Foz, $\Delta 6$ - Rio do Júlio, $\Delta 7$ - Rio Pirai, $\Delta 8$ - RVPSC, $\Delta 9$ - Res. Norte, $\Delta 10$ - Escola Técnica Tupy, $\Delta 11$ - Estrada Blumenau Km 18. Em amarelo: limites de bacias hidrográficas. Em vermelho: Rodovias.

A metodologia empregada para definir os valores do balanço hídrico constou de:

- Levantamento dos índices fluviométricos e pluviométricos nos postos em operação e naqueles já desativados,

- Análise das séries históricas de cada estação,

- Definição da série histórica para cada bacia. As informações para bacias com mais de uma estação pluviométrica / fluviométrica foram homogeneizadas, usando como base o período de coleta de informações coincidente entre as estações envolvidas, independentemente da série histórica de cada uma.

- Tratamento estatístico dos dados,

- Interpretação dos dados e cálculo do balanço. 
Os maiores problemas encontrados durante a execução deste trabalho foram a análise e a interpretação de séries históricas que muitas vezes encontram-se incompletas e com erros inseridos quer por transcrição de dados, digitação ou por leitura duvidosa. Isto ficou muito claro na fase final de cálculo onde os valores de pluviosidade, descarga fluvial e evapotranspiração foram analisados para definir a infiltração.

A Bacia do Rio Cubatão foi a que apresentou a maior confiabilidade dos dados calculados, seguido pelas informações da Bacia do Rio Cachoeira. Para as Bacias do Rio do Júlio / Itapocuzinho e Bacia do Rio Pirai, os cálculos efetuados não são consistentes uma vez que o banco de dados apresenta inúmeros problemas.

Na última fase de cálculo do Balanço hídrico foi utilizada equação que segue:

$$
\mathbf{P}=\mathbb{C}+\mathbb{R}+\quad \text { onde, }
$$

- Precipitação (medida a partir da interpretação dos dados obtidos junto às estações pluviométricas)

- $\mathbf{E}=$ Evapotranspiração (medida a partir da análise e interpretação dos valores detectados pelas estações)

- Rscoamento (Run off, calculado a partir das medidas de descargas dos postos fluviométricos), e

- I :-: Infiltração (calculada a partir da formula acima descrita. Inclui a retenção de água pelo solo, parcela infiltrada que alimenta os mananciais superficiais e a recarga do aqüifero). 


\section{2 - Análise do balanço hídrico da Bacia do Rio Cachoeira:}

A Bacia do Rio Cachoeira é uma bacia concêntrica, e está situada na parte central da área urbana. Apresenta uma área de aproximadamente $84 \mathrm{Km}^{2}$ e o talvegue principal apresenta comprimento em torno de $15 \mathrm{~km}$.

É uma bacia que sofre efeitos de maré. Isto para o municipio representa um sério problema, uma vez que as cotas da área central apresentam valores próximos a $2,0 \mathrm{~m}$. Muitas vezes o fenômeno de maré de sigízia inunda o centro da cidade sem a necessidade de chuva, como aconteceu em 06 de abril deste ano. Este evento quando associado a precipitações pluviométricas agrava ainda mais o problema das enchentes no meio urbano.

A concentração das chuvas em janeiro, fevereiro e março tem papel relevante no que se refere ao aumento do potencial de erosão dos solos de áreas sem cobertura vegetal ou degradadas por terraplanagem. Neste período, o efeito imediato é o transporte de sedimentos e a conseqüente contribuição ao assoreamento do sistema de drenagem do Rio Cachoeira. Esta é a época do ano que mais ocorrem cheias no centro da cidade. As tubulações que deságuam no rio apresentam problemas de seçôes obstruídas o que diminui sua capacidade de transporte e de armazenamento em caso de maré alta.

As estações pluviométricas utilizadas para avaliar o balanço hídrico da bacia do rio Cachoeira estão inseridas na tabela 11.

Tabela 11 : Estacẽes utilizadas para determinar o balanco hídrico da bacia do Cachocira

\begin{tabular}{c|c|c|c}
\hline POSTO & SERIE HISTORICA & Periodo coincidente & DESCRICÃO \\
\hline DNAEE RVPSC & $1940-1980$ & $1971-1980$ & Pluviométrico \\
\hline DNAEE Res. Norte & $1953-1984$ & $1971-1980$ & Pluviométrico \\
\hline Escola Técnica TUPY & $1971-1996$ & $1971-1980$ & Pluviométrico \\
\hline
\end{tabular}

\subsection{1 - Avaliação da pluviometria.}

A avaliação pluviométrica da Bacia do Rio Cachoeira partiu das informações de pluviosidade das estações existentes, listadas na tabela 11 O critério utilizado para definir a série histórica para a bacia foi a unificação das informações geradas pelas estações, no período de tempo de coleta coincidente entre elas, ou seja de 1971 a 1980. As estações utilizadas serão descritas a seguir: 


\section{- RVPSC- DNAEE}

Esta estação localiza-se na atual estação Ferroviária, zona sul da cidade e está desativada. Apresenta dados desde 1940 até 1980 (série histórica de 40 anos).

Durante o período de 1971 a 1980, a estação apresentou uma média de chuvas anual em torno de $1919,78 \mathrm{~mm}$.

A figura 4 mostra a variação média mensal.

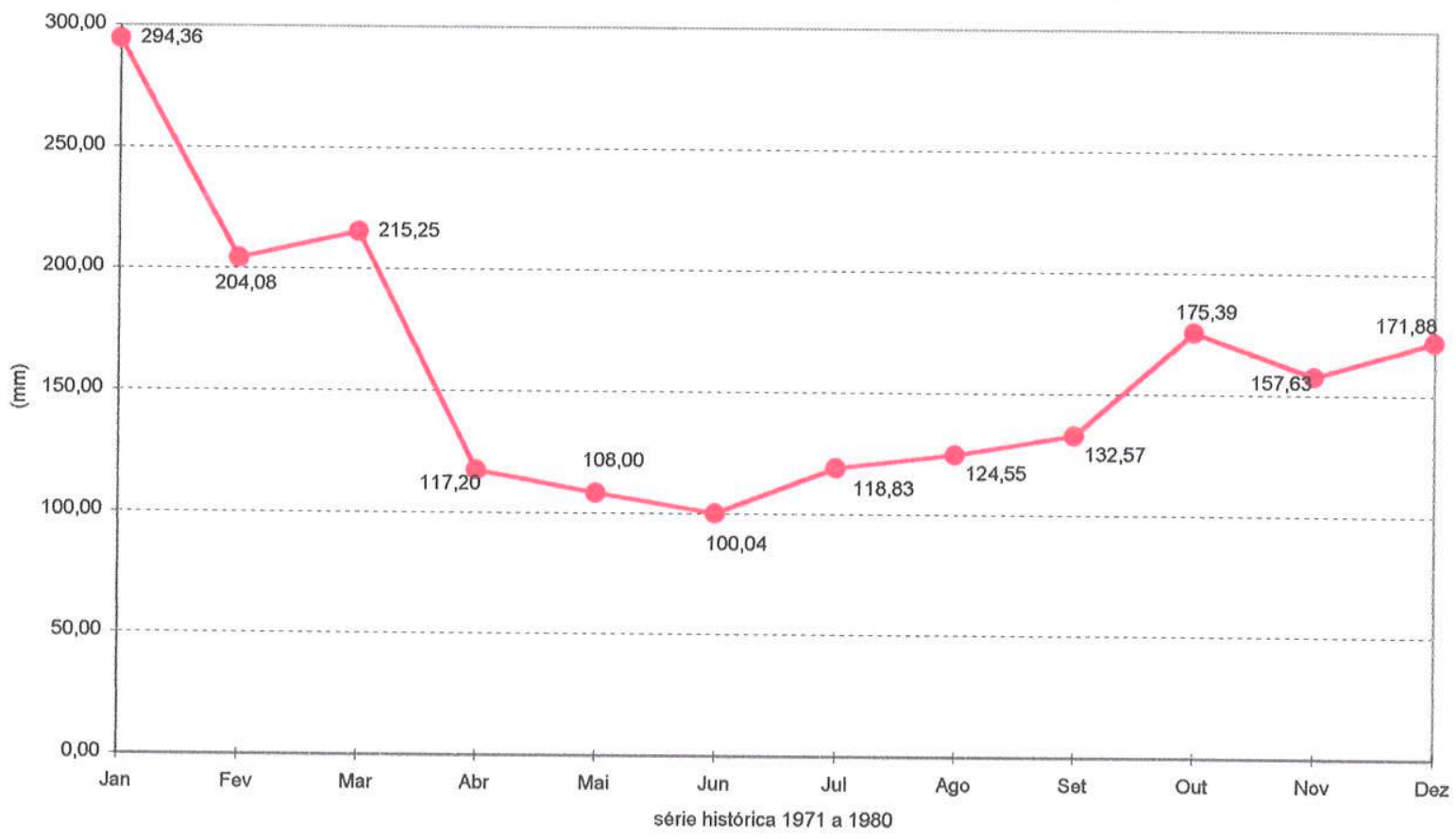

Figura 4: Variação média mensal da pluviosidade. Estação RVPSC - DNAEE 


\section{- RES NORTE- DNAEE}

Esta estação também está desativada. Situa-se onde é atualmente a secretaria de Habitação da Prefeitura Municipal de Joinville na Rua Hermann Lepper, divisa da área central com o bairro Saguaçu. Apresenta informações de 1953 até 1984, ano que foi desativada.

Como no caso da estação RVPSC foram utilizados as informações de 1971 a 1980. A média anual deste período foi de 1949,12 mm, conforme mostra a figura 5 .

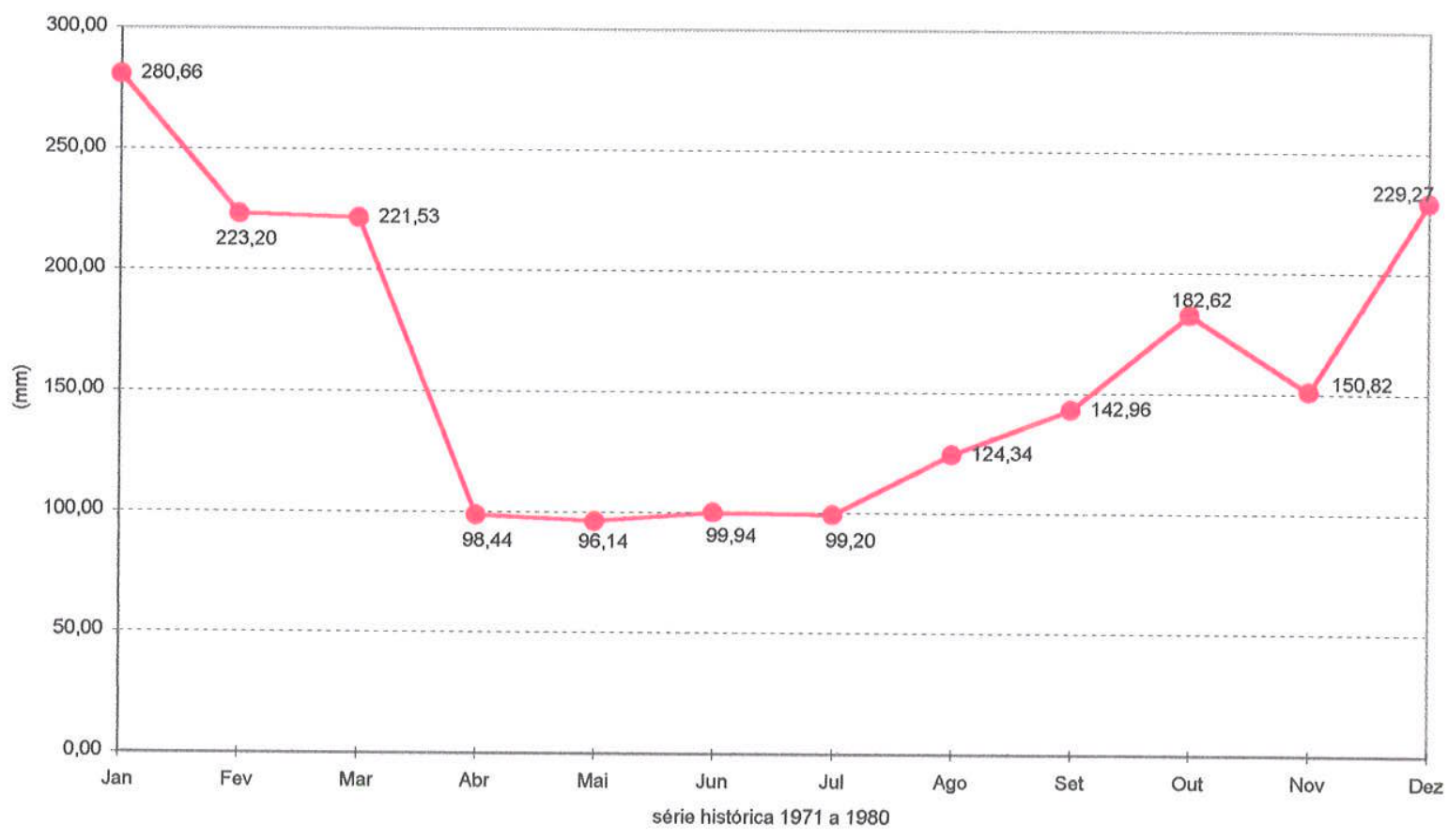

Figura 5: Variação média mensal da pluviosidade. Estação Res. Norte - DNAEE 


\section{- ESCOLA TÉCNICA TUPY}

A estação da Escola Técnica Tupy (ETT) situa-se no Bairro Boa Vista na Rua Prefeito Helmut Fallgatter. Iniciou sua atividade em 1971 e está em operação até hoje.

Durante o Período de 1971 a 1980 apresenta média anual de 1904,18 mm. As médias mensais do mesmo período estão inseridas na figura 6 .

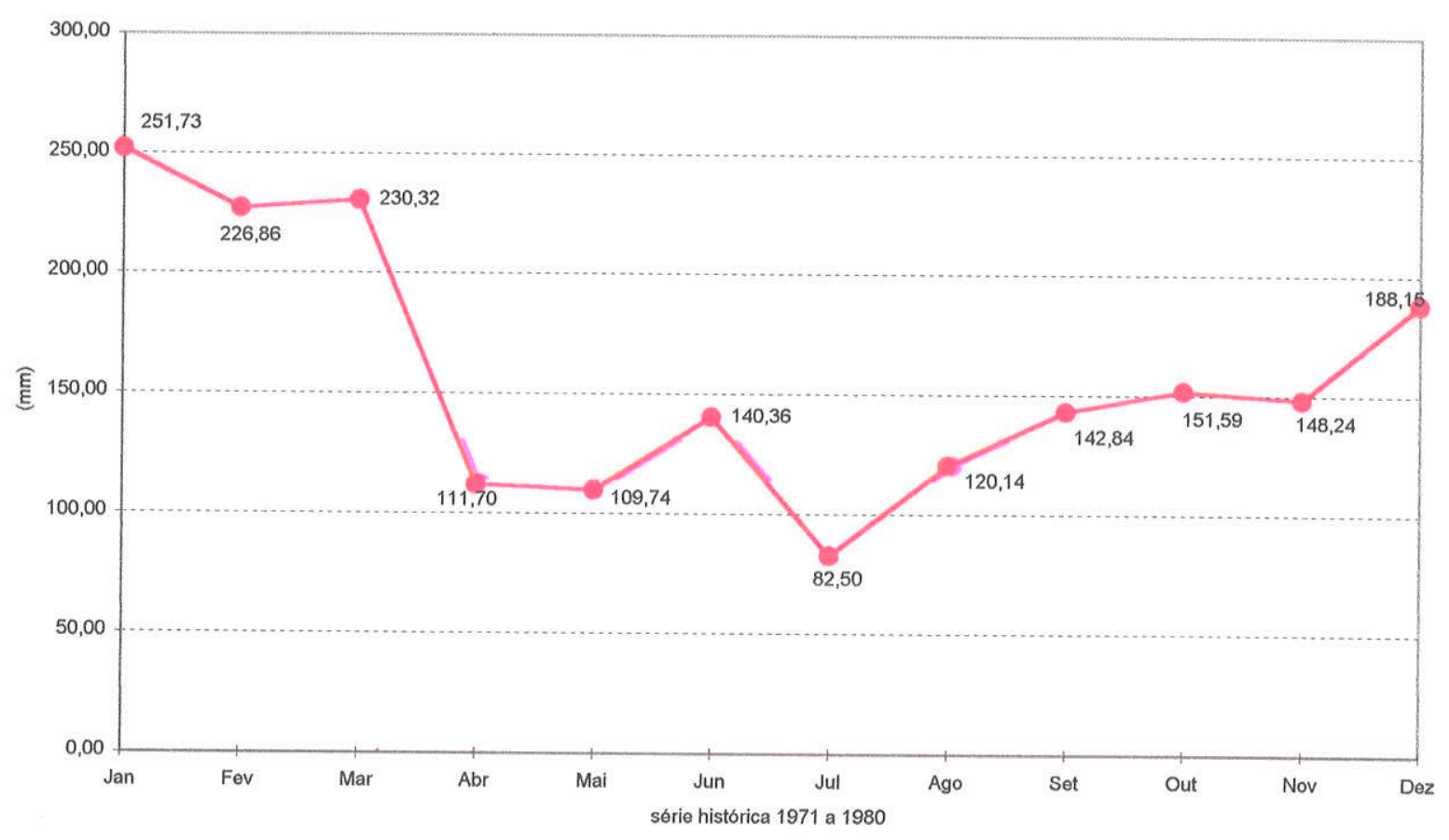

Figura 6: Variação média mensal da pluviosidade. Estação ETT.

\subsection{2 - Avaliação da descarga fluvial:}

Durante a execução deste trabalho não se teve conhecimento de séries históricas pluviométricas maiores do que o período de um (01) ano. GONÇALVES (1993) descreve o posto fluviométrico do Rio Cachoeira com área de $77,5 \mathrm{~km}$ e vazão média anual de $5,29 \mathrm{~m}^{3} / \mathrm{h}$. O período de observação foi de 1990 a 1991.

Em 1985 o CEHPAR realizou estudos de simulação de escoamento do Rio Cachoeira e estabeleceu as alturas de chuvas extremas estimadas para o Rio Cachoeira com Tempo de Recorrência de 100 anos. O resultado daquela pesquisa está inserido na tabela 12. 
Tabela 12: Alturas de chuvas extremas calculadas nos estudos de simulação de escoamento do Rio Cachoeira (CEHPAR 1985)

\begin{tabular}{c|c}
\hline Duração da chuva (minutos) & Altura de chuva (mm) \\
\hline 30 & 87 \\
\hline 60 & 135 \\
\hline 90 & 166 \\
\hline 120 & 194 \\
\hline 150 & 214 \\
\hline 180 & 230 \\
\hline 210 & 244 \\
\hline
\end{tabular}

O mesmo relatório determinou, por comparação às bacias da região as vazões de cheias para a bacia do Rio Cachoeira, descritas na tabela 13 .

Tabela 13: Vazóes de cheias para a Bacia do Rio Cachoeira (CEHPAR 1985)

\begin{tabular}{c|c|c}
\hline Tempo de Retorno (anos) & $\begin{array}{c}\text { Vazôes de cheia }- \text { Ponte do } \\
\text { Trabalhador } 51 \mathrm{~km}^{2}-\mathrm{m}^{3} / \mathrm{s}\end{array}$ & $\begin{array}{r}\text { Vazôes especificas de cheia } \\
\mathrm{m}^{3} / \mathrm{s} / \mathrm{km}^{2}\end{array}$ \\
\hline 2 & 109.8 & 2.14 \\
\hline 10 & 183.6 & 3.57 \\
\hline 25 & 243.6 & 4.74 \\
\hline 50 & 308.4 & 6.00 \\
\hline 100 & 379.8 & 7.39 \\
\hline
\end{tabular}

Aquele estudo admitiu ainda um coeficiente de escoamento de $60 \%$ para a Bacia do Rio Cachoeira, dada a ocupação urbana do entorno.

5.2.3 - Avaliação da evapotranspiração potencial:

Os valores de evapotranspiração referentes à Bacia do Rio Cachoeira, utilizados neste estudo são aqueles detectados pela estação pluviométrica da Escola Técnica Tupy. A série histórica avaliada é a mesma utilizada para definir os demais parâmetros do balanço hídrico, ou seja de 1971 até 1980.

A figura 7 define os valores médios mensais (em $\mathrm{mm}$ ) e apresenta um total médio anual de $389,18 \mathrm{~mm}$. 


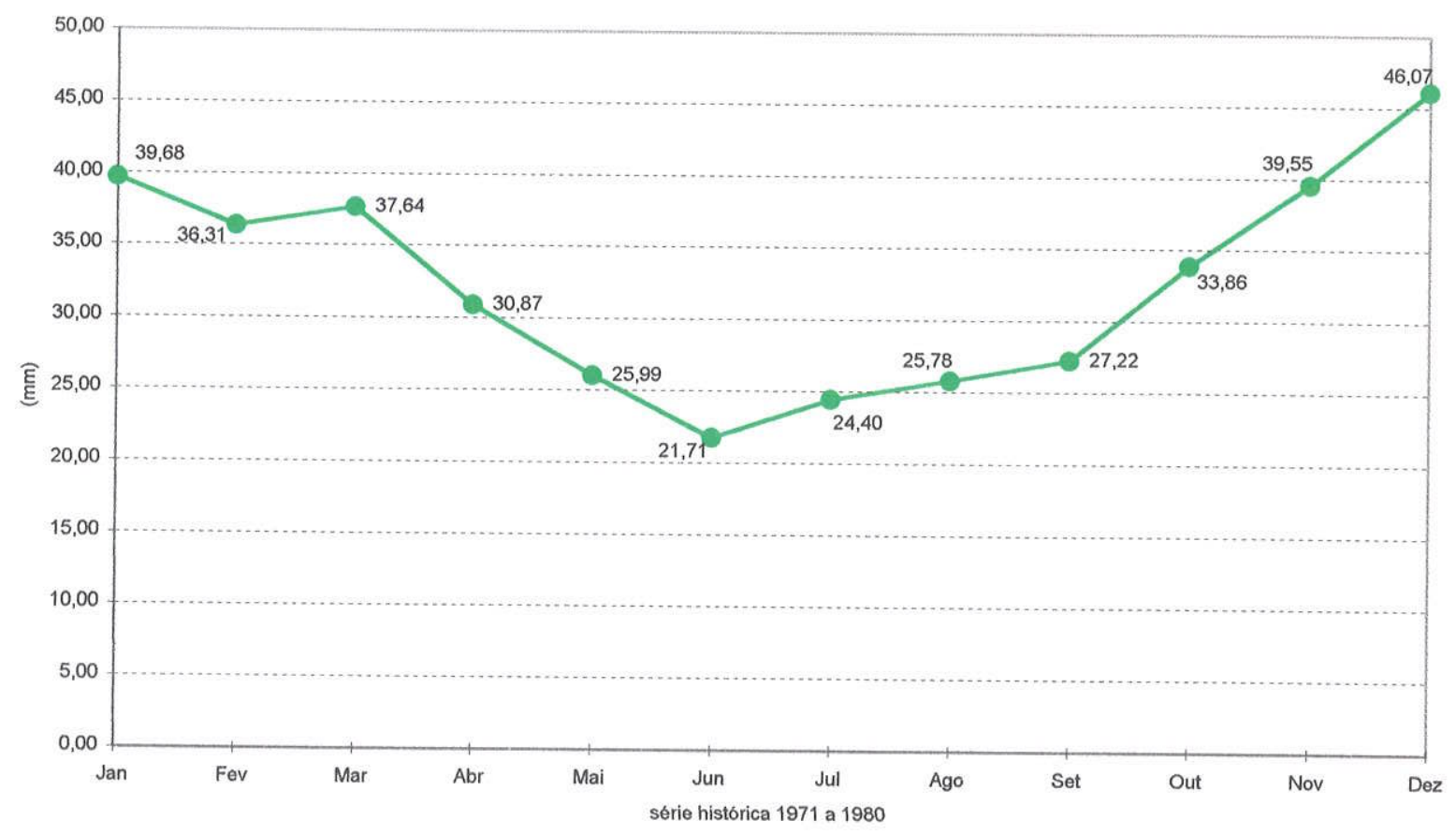

Figura 7: Variação média mensal da evapotranspiração - Estação ETT

A partir disso determinou-se que o comportamento hídrico da Bacia do Cachoeira apresenta descarga fluvial (Run off) próxima de $60 \%$ da precipitação pluviométrica (CEHPAR, 1986) e três fontes de recarga do aqüífero conforme segue:

1. Recarga pluviométrica (100\% da Bacia) e

2. Recarga por ingressão de águas do mar (ao longo do canal e com maior influência na seção terminal da bacia - 10\% da Bacia). Esta recarga gerou uma zona de grande influência de cloretos na composição da água (ver anexo II). Foram observadas estas características nos poços n. ${ }^{\circ} 6,59,112$ e 113. Por outro lado esta zona de influência atinge apenas as entradas de água superficiais. Em poços em que a cimentação anular isolou estas entradas superficiais (poço 7), o teor de cloretos decaiu para valores totalmente normais dentro da amostragem.

3. Recarga induzida pelas perdas da CASAN $\left(2105 \mathrm{~m}^{3} / \mathrm{h}\right)$

\subsection{4 - Cálculo do balanço hídrico}

O balanço hídrico da Bacia do Cachoeira foi desenvolvido a partir de dados confiáveis de pluviosidade. Apesar da série histórica completa das três estações apresentar um deslocamento de tempo com coincidência de apenas 10 anos, as médias comparadas são muito semelhantes e mostraram comportamento similares. A partir disso calculou-se que a entrada de água doce no sistema é da ordem de 1,9 milhões de $\mathrm{m}^{3} / \mathrm{km}^{2} /$ ano 
Com relação às saídas de água, a tabela 14 resume estas informações:

Tabela 14: Volumes de água do balanço hídrico da Bacia do Rio Cachoeira.

\begin{tabular}{c|c|c}
\hline Balanço Hídrico & Volume & Percentual \\
\hline \hline Evaporação & $389.180 \mathrm{~m}^{3} / \mathrm{km}^{2} /$ ano & $20.22 \%$ \\
\hline Descarga Fluvial & $1.154 .616 \mathrm{~m}^{3} / \mathrm{km}^{2} /$ ano & $60 \%$ \\
\hline Infiltração & $380.564 \mathrm{~m}^{3} / \mathrm{km}^{2} /$ ano & $19.78 \%$ \\
\hline
\end{tabular}

A partir destas informações infere-se que a recarga natural do aqüífero fraturado na área de influência da bacia do Rio Cachoeira alcança $31.967 .376 \mathrm{~m}^{3} / \mathrm{ano}$.

A figura 8 mostra o comportamento do balanço hídrico ao longo do ano e deve ser lida da seguinte forma: Em vermelho observa-se o total das chuvas (100\%) que se divide nas demais cores que correspondem aos percentuais descarga fluvial (azul), infiltração (amarelo) e de evaporação (verde).

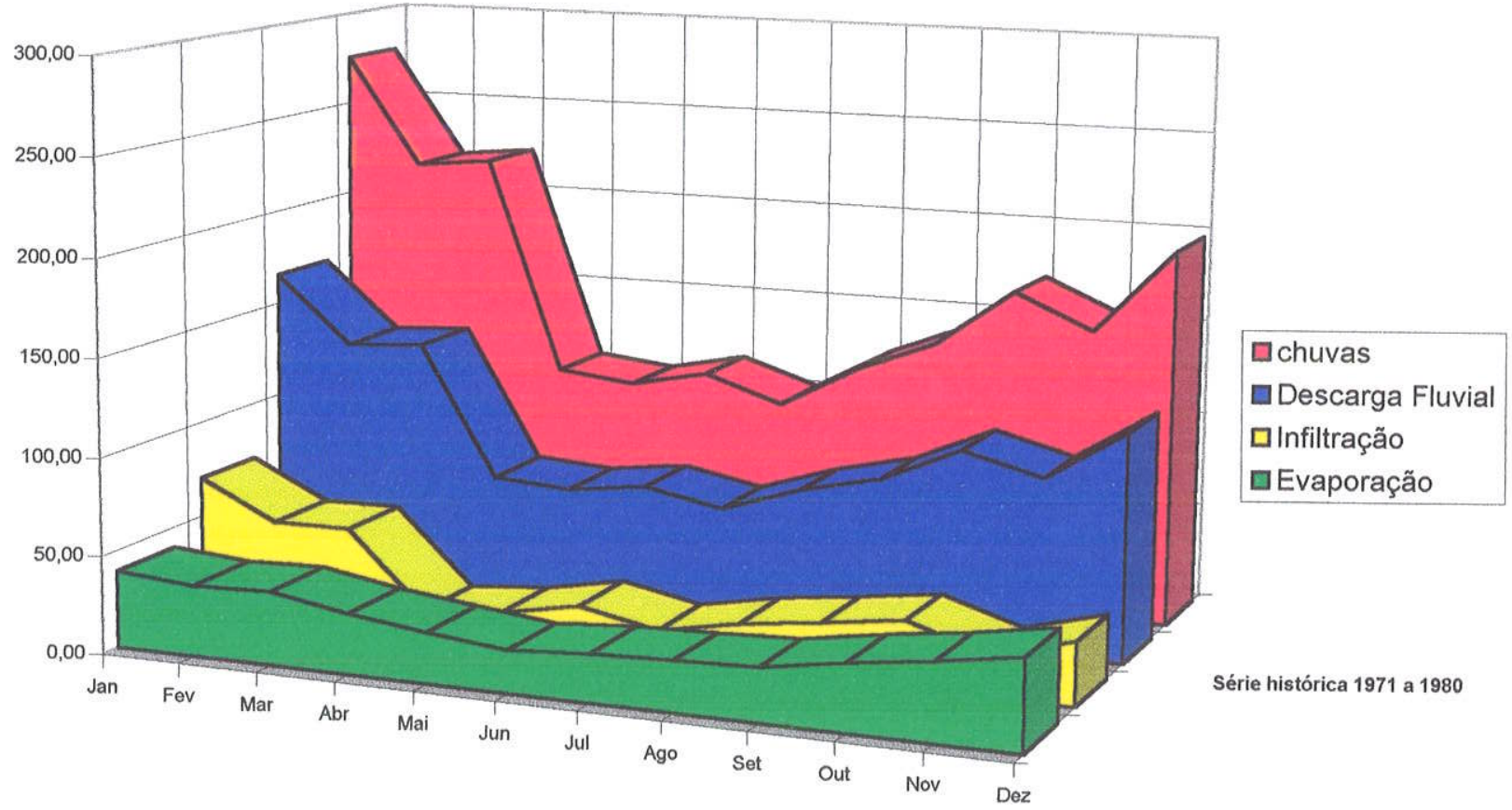

Figura 8 : comportamento hídrico anual na Bacia do Rio Cachoeira.

Exclusivamente para a Bacia do Rio Cachoeira, que ocupa a área de estudo da presente dissertação foi realizada uma análise mais detalhada da parcela infiltrada. O significado da parcela que se infiltra retrata a recarga do aqüífero. 
A função estratégica da água subterrânea, que é regularizar as ofertas de água do sistema, reduzir os impactos de uma catástrofe hidrológica (enchentes ou secas) e tornar-se vital em caso de acidente com carga tóxica sobre o manancial superficial. Neste caso o manancial subterrâneo atenderia as demandas vitais, estimadas em $30 \%$ do consumo total, ou seja $780 \mathrm{~m}^{3} / \mathrm{h}$, o que corresponde a $22 \%$ da água infiltrada.

Para esta avaliação foi considerado que a produção dos poços é estável e em tomo de $690 \mathrm{~m}^{3} / \mathrm{h}$, portanto, em média está sendo explotado do aqǘfero fraturado $18 \%$ do valor infiltrado. Estima-se, no entanto, que o valor explotado, via poços tubulares profundos, poderá chegar no mínimo a $35 \%$ do valor infiltrado, ou seja $1300 \mathrm{~m}^{3} / \mathrm{h}$. Esta estimativa baseia-se no fato de que a grande maioria dos poços está locada fora da área de lineamentos (ítem 7.7) e apresentam vazões médias de 1 a $3 \mathrm{~m}^{3} / \mathrm{h}$, enquanto que os poços bem locados apresentam vazões que ultrapassam $10 \mathrm{~m}^{3} / \mathrm{h}($ item $6 \mathrm{e}$ )

Considerando que a inserção de água subterrânea é complementar, a implantação de um sistema misto, com poços tubulares profundos com produção minima de $10 \mathrm{~m}^{3} / \mathrm{h}$ é favorável. O cruzamento das informações,

- recarga do sistema aqüífero,

- lineamentos (ítem 7.5),

- déficit do sistema de abastecimento de água (item 4.2.1),

- vazões de água subterrânea atualmente explotadas (ítem 4.2.2),

- custos de perfuração de poços tubulares profundos (ítem 4.3),

e considerando que

- existem reais possibilidades de acontecer acidentes rodoviários que inviabilizem a oferta de água tratada, e

- períodos de enchentes e estiagens podem suspender ou diminuir as ofertas de água tratada

estima-se que existe viabilidade técnica econômica, para implantar o sistema proposto com aumento da contribuição da água subterrânea para regularizar o sistema de abastecimento de água de Joinville.

Por outro lado, será ainda necessário um estudo hidrogeológico especifico que objetive avaliar como a água se comporta no aqüífero ou seja, como flui e quanto é estocada. 
5.3 - Análise do balanço hídrico da Bacia do Rio Cubatão:

A bacia do Rio Cubatão situa-se no Norte do Município e suas nascentes, na Serra do Mar, estão em altitudes que chegam a 1527m (KRAEMLING, 1995). O talvegue principal apresenta extensão em torno de $70 \mathrm{~km}$ e a bacia tem uma área total de aproximadamente 463 $\mathrm{km}^{2}$. O rio Cubatão apresenta, ao longo de seu curso principal, variação granulométrica de seus sedimentos. À montante tem-se matacões e blocos de rochas cristalinas, em seu curso médio predomina seixos rolados com granulometria variável (diâmetro de 10 a $70 \mathrm{~cm}$ ) e a jusante, próximo à foz, os fácies areia e argila são dominantes.

Para efetuar a análise hídrica da bacia do rio Cubatão, foram utilizadas as informações de postos fluviométricos e pluviométricos coincidentes com o período de 1950 a 1972 , e a bacia foi dividida em quatro sub-bacias: Salto 1, Quiriri, Barragem e Foz.

Os postos pluviométricos e fluviométricos utilizados para esta análise estão listados na tabela 15 .

Tabela 15: Estações utilizadas para determinar o balanço hídrico da Bacia do Rio Cubatão.

\begin{tabular}{l|l|c|c}
\hline POSTO & CODIGO & SERIE HISTORICA & DESCRICAO \\
\hline DNAEE - Salto 1 & $02649 \mathrm{PF}$ & $1950-1972$ & $\begin{array}{l}\text { Fluviométrico } \\
\text { Pluviométrico }\end{array}$ \\
\hline DNAEE - Salto 2 & & $(*)$ & Pluviométrico \\
\hline DNAEE - Quirit & $264921 \mathrm{PF}$ & $1956-1967$ & $\begin{array}{l}\text { Fluviométrico } \\
\text { Pluviométrico }\end{array}$ \\
\hline Barragem & Planepar (1989) & $1950-1972$ & Fiuviométrico \\
\hline Foz & Planepar (1989) & $1950-1972$ & Fluviométrico \\
\hline
\end{tabular}

(*) estações uililizadas apenas como referéncia

\subsection{1.- Avaliação da pluviometria}

Os registros pluviométricos da Bacia do Rio Cubatão foram largamente estudados por PLANEPAR (1973), e também por ENGEVIX (1989) que elaborou o EIA-RIMA para implantação de uma usina hidrelétrica na Bacia do Rio Cubatão.

Os dados são oriundos dos postos pluviométricos do DNAEE (salto 1 e Quiriri). 
A análise para a estação do salto 1 (figura 9) mostra uma variação da média mensal de chuva no período de 1950 a 1972, de 169,74 a 428,61 mm/mês. O total anual é de $3.482,47 \mathrm{~mm}$ o que representa um valor/ano médio mensal, no período, de 290,20 $\mathrm{mm}$.

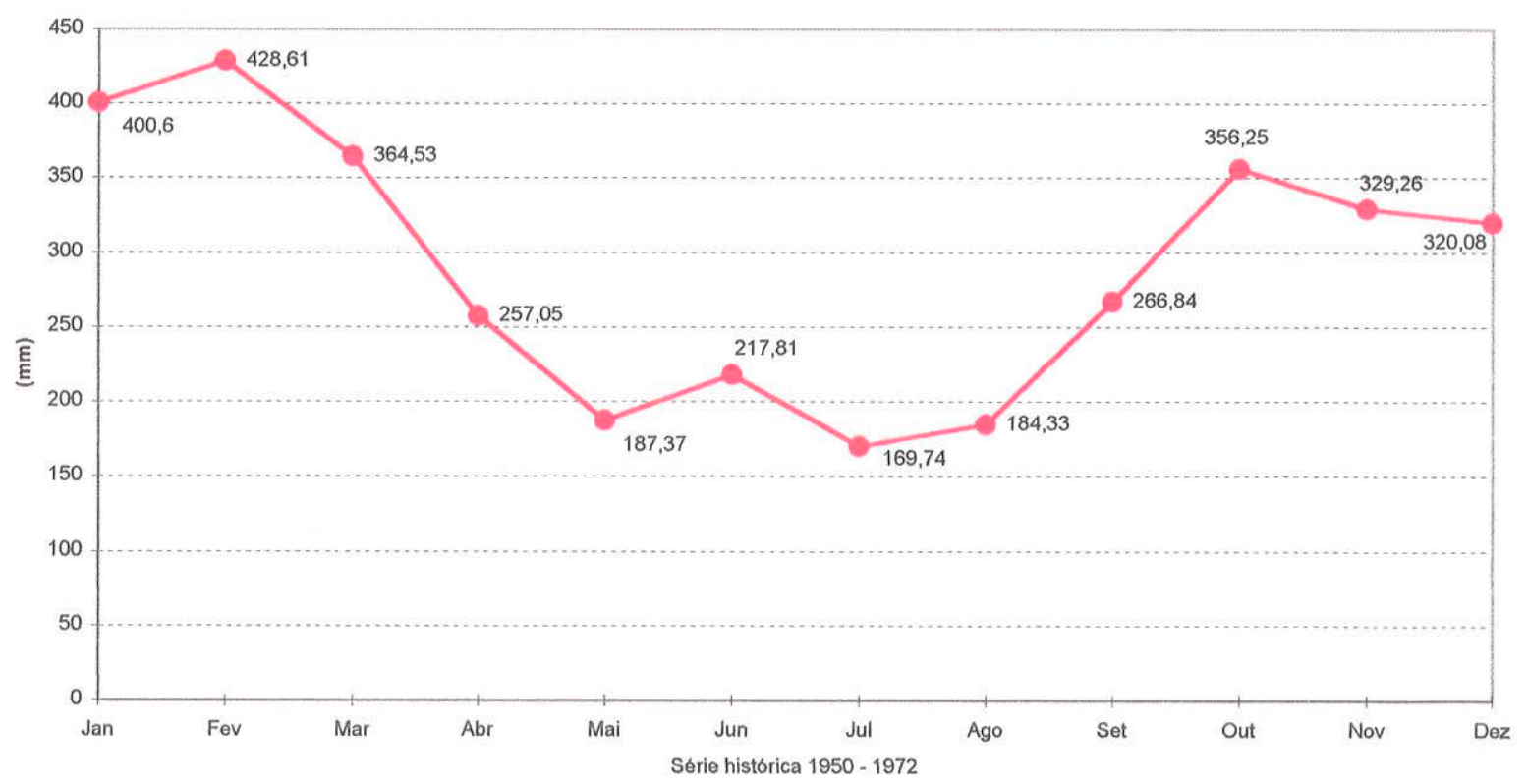

Figura 9: Variação média mensal da pluviosidade. Estação DNAEE salto 1 (código 02649PF)

Já a estação Quiriri, apresentou um valor anual acumulado de 2.325,81 mm com média mensal de 193,82 mm, conforme a figura 10, a seguir.

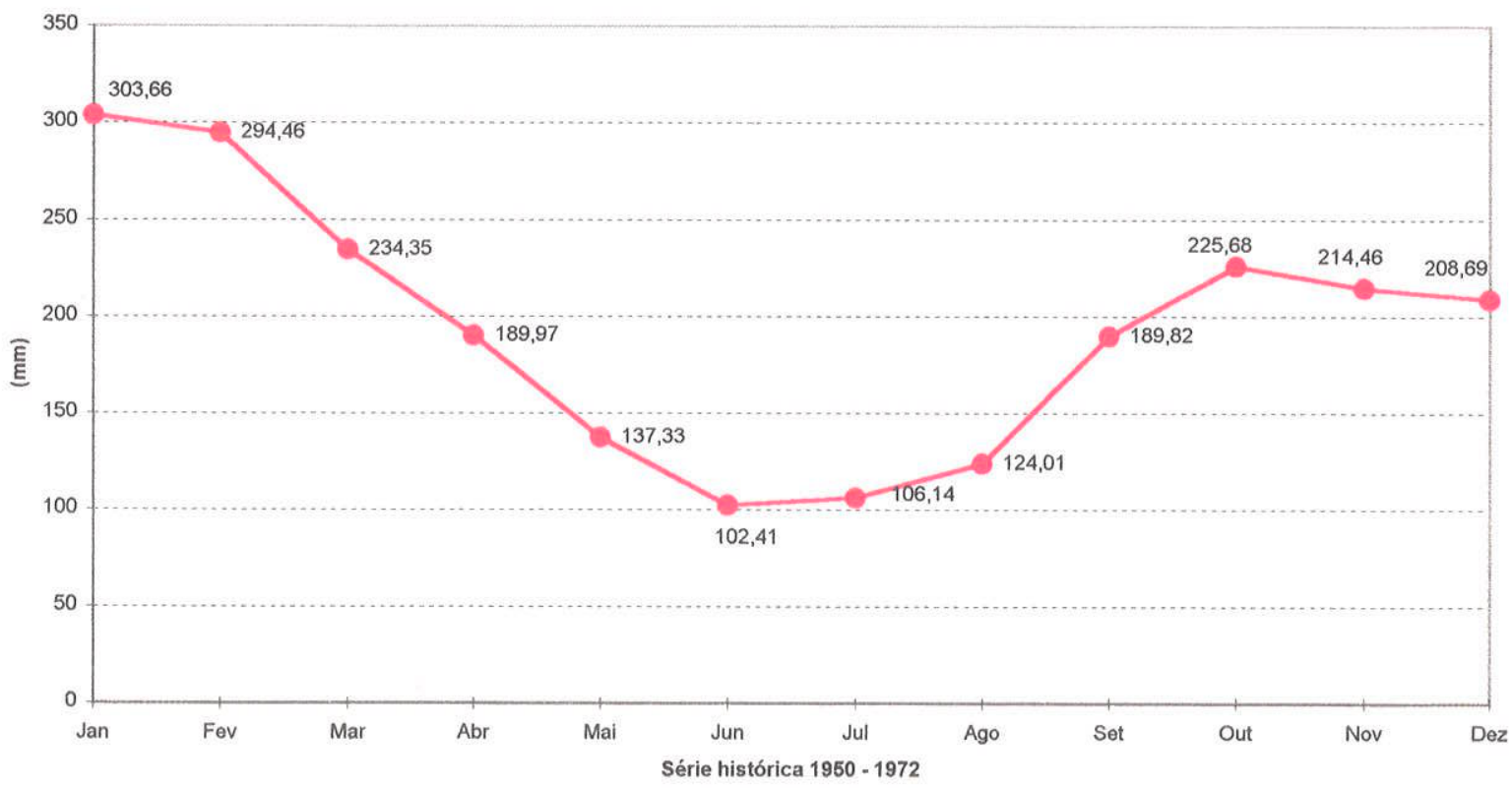

Figura 10 : Variação média mensal da pluviosidade - Estação DNAEE Quiriri (código 264921PF) 


\subsection{2 - Avaliação da descarga fluvial:}

Os postos fluviométricos da Bacia do Rio Cubatão utilizados neste estudo foram o do Salto 1: Estação DNAEE código 26499 PF, Quiriri Estação DNAEE código 264921 PF, Estação Barragem e Estação Foz. A série histórica abrangeu o período de 1950 a 1972.

A figura 11, abaixo mostra as médias mensais de descarga do Rio Cubatão $\left(\mathrm{m}^{3} / \mathrm{s}\right)$

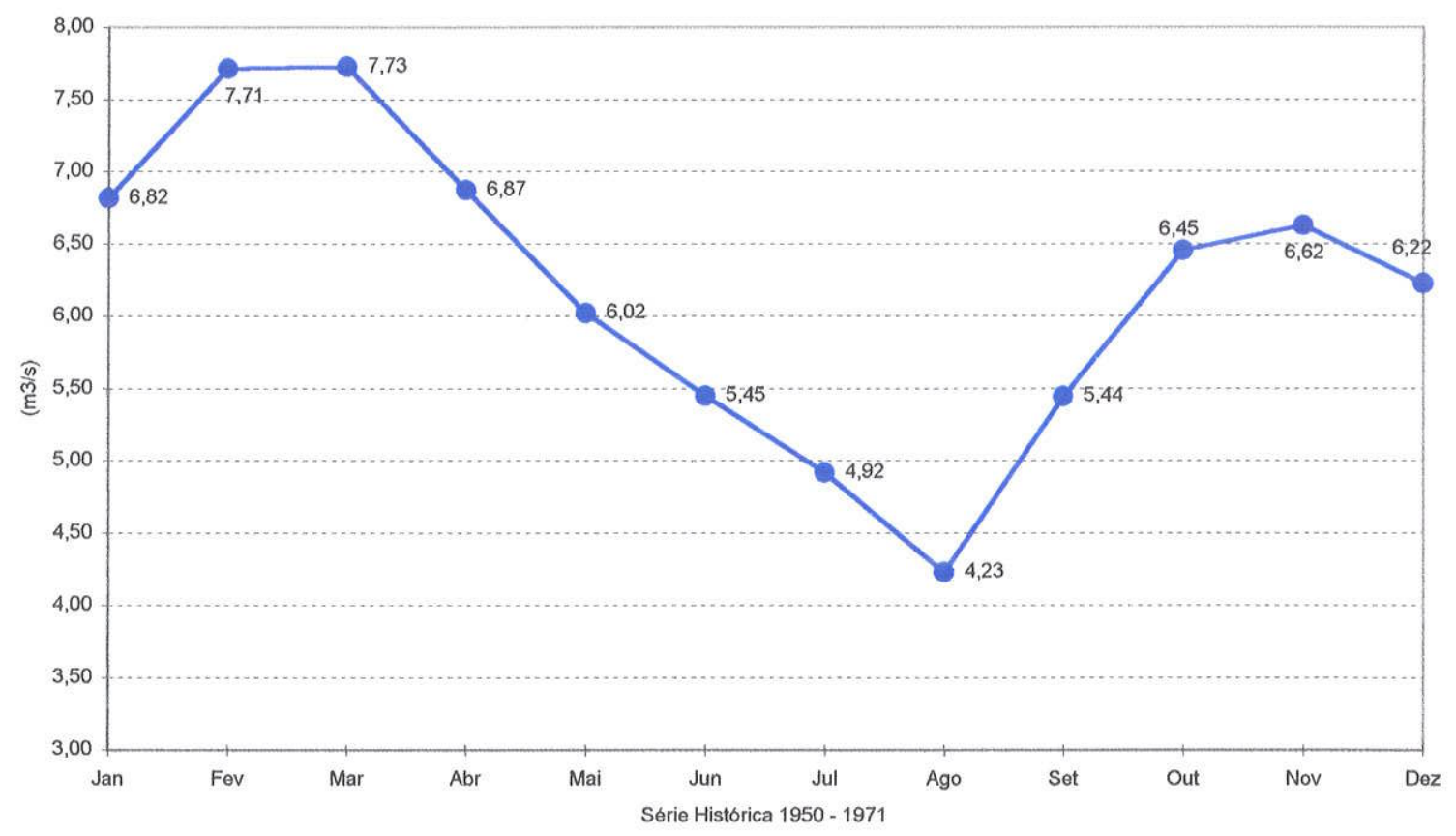

Figura 11: Variação média mensal da descarga fluvial - Estação Salto 1.

A maior descarga constatada na estação salto 1, no período de 1950 a 1971 foi no mês de março $\left(7.73 \mathrm{~m}^{3} / \mathrm{s}\right)$ e a menor descarga pluvial foi constatada no mês de agosto $\left(4,23 \mathrm{~m}^{3} / \mathrm{s}\right)$. Comparativamente com a pluviosidade, no mesmo período, as maiores chuvas foram registradas em fevereiro $(428,61 \mathrm{~mm})$ e as menores em Julho $(169,74 \mathrm{~mm})$. sugerindo uma correlação chuva-descarga em espaço de tempo definido. Esta correlação persiste para os demais períodos, com exceção às chuvas do mês de junho e as descargas do mês de julho.

O resultado da descarga da bacia está inserido na tabela 16 abaixo:

Tabela 16: Descarga fluvial da Bacia do Rio Cubatão

\begin{tabular}{c|c|c|c|c}
\hline ÁREA & $\begin{array}{c}\text { CHUVA } \\
\text { m3/ano (P) }\end{array}$ & $\begin{array}{c}\text { Descarga média e } \\
\text { específica }\end{array}$ & $\begin{array}{c}\text { Lâmina Escoada } \\
\text { m3/ano (R) }\end{array}$ & $\begin{array}{c}\text { Correlação } \\
\text { P/R }(\%)\end{array}$ \\
\hline $463 \mathrm{~km}^{2}$ & 1,6 bilhões & $\begin{array}{c}24,42 \mathrm{~m}^{3} / \mathrm{s} \\
52,741 / \mathrm{s} . \mathrm{km}\end{array}$ & 787,1 milhões & $49.2 \%$ \\
\hline
\end{tabular}




\subsection{3 - Avaliação da Evapotranspiração Potencial:}

Os valores adotados para a análise da evapotranspiração da bacia do Rio Cubatão, foram aqueles levantados no estudo de viabilidade da Usina Hidrelétrica Cubatão (ENGEVIX, 1989), a partir das informações da estação de salto 2. A figura 12 define os valores médios mensais (mm) sendo a média anual de $1114 \mathrm{~mm}$.

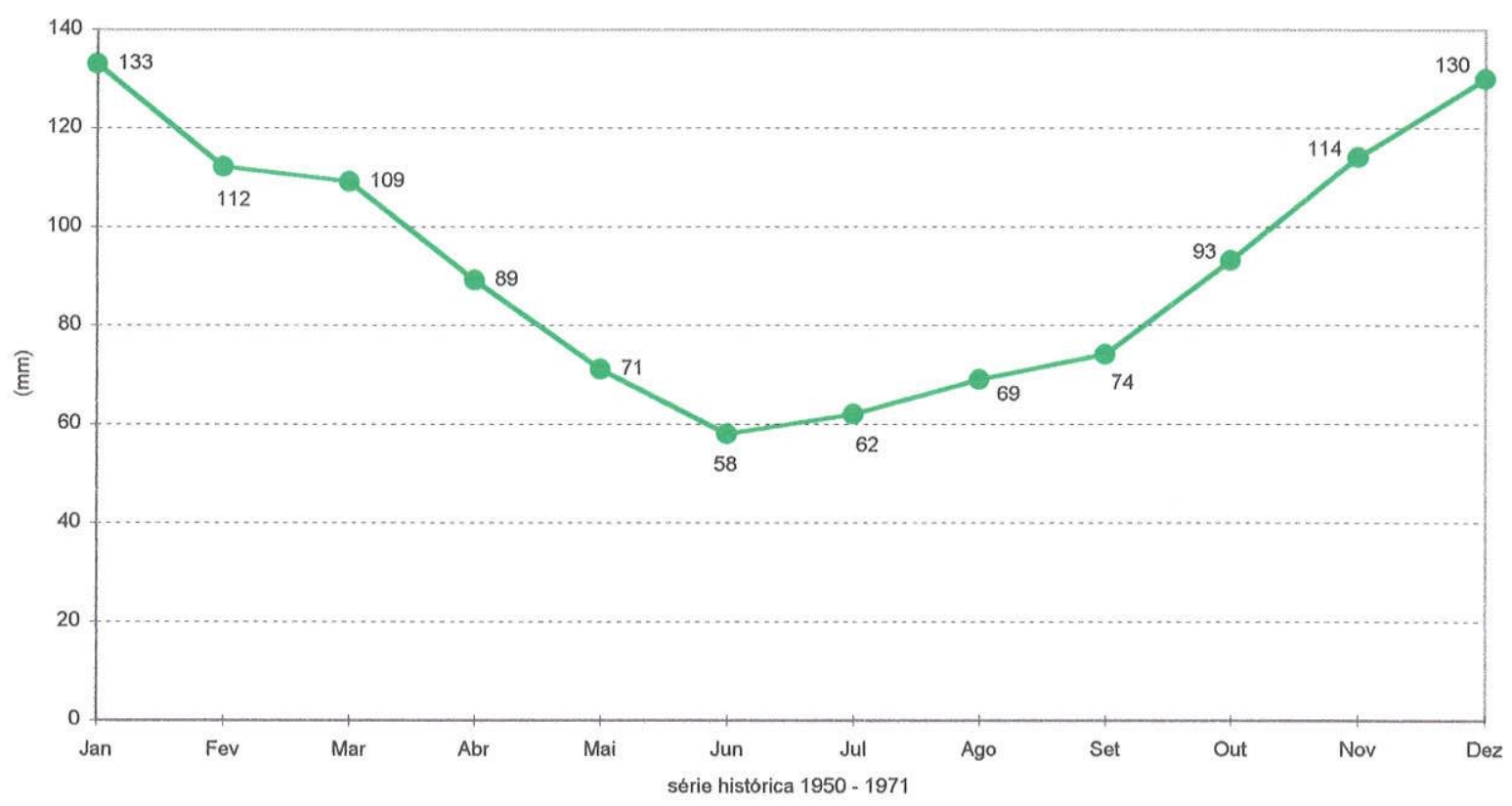

Figura 12 : Variação média mensal da evapotranspiração. Estação Salto 2.

\subsection{4 - Cálculo do balanço hídrico.}

O balanço hídrico calculado para a Bacia do Rio Cubatão mostrou que a quantidade de chuva que cai no sistema é da ordem de 3,5 milhões $\mathrm{de}^{3} / \mathrm{km}^{2} /$ ano e representam 1,6 bilhões de $\mathrm{m}^{3}$ de água por ano.

A evapotranspiração atinge 1,1 milhão de $\mathrm{m}^{3} / \mathrm{km}^{2} /$ ano, o que corresponde a 32,01\% da chuva.

A descarga fluvial é responsável pelo transporte de 1,7 milhão de $\mathrm{m}^{3} / \mathrm{km}^{2} /$ ano o que representa $47,79 \%$ da água que ingressou no sistema. 
Finalmente a infiltração que alimenta os aqüíferos representa $20,2 \%$ da chuva que cai na Bacia do Rio Cubatão, e representa 0,7 milhão de $\mathrm{m}^{3} / \mathrm{km}^{2}$ de água por ano.

A figura 13 define o resultado do Balanço hídrico para a Bacia do Rio Cubatão e deve ser lida da seguinte forma: Em vermelho observa-se o total das chuvas (100\%) que se divide nas demais cores que correspondem aos percentuais de descarga fluvial (azul), de evaporação (verde) e infiltração (amarelo).

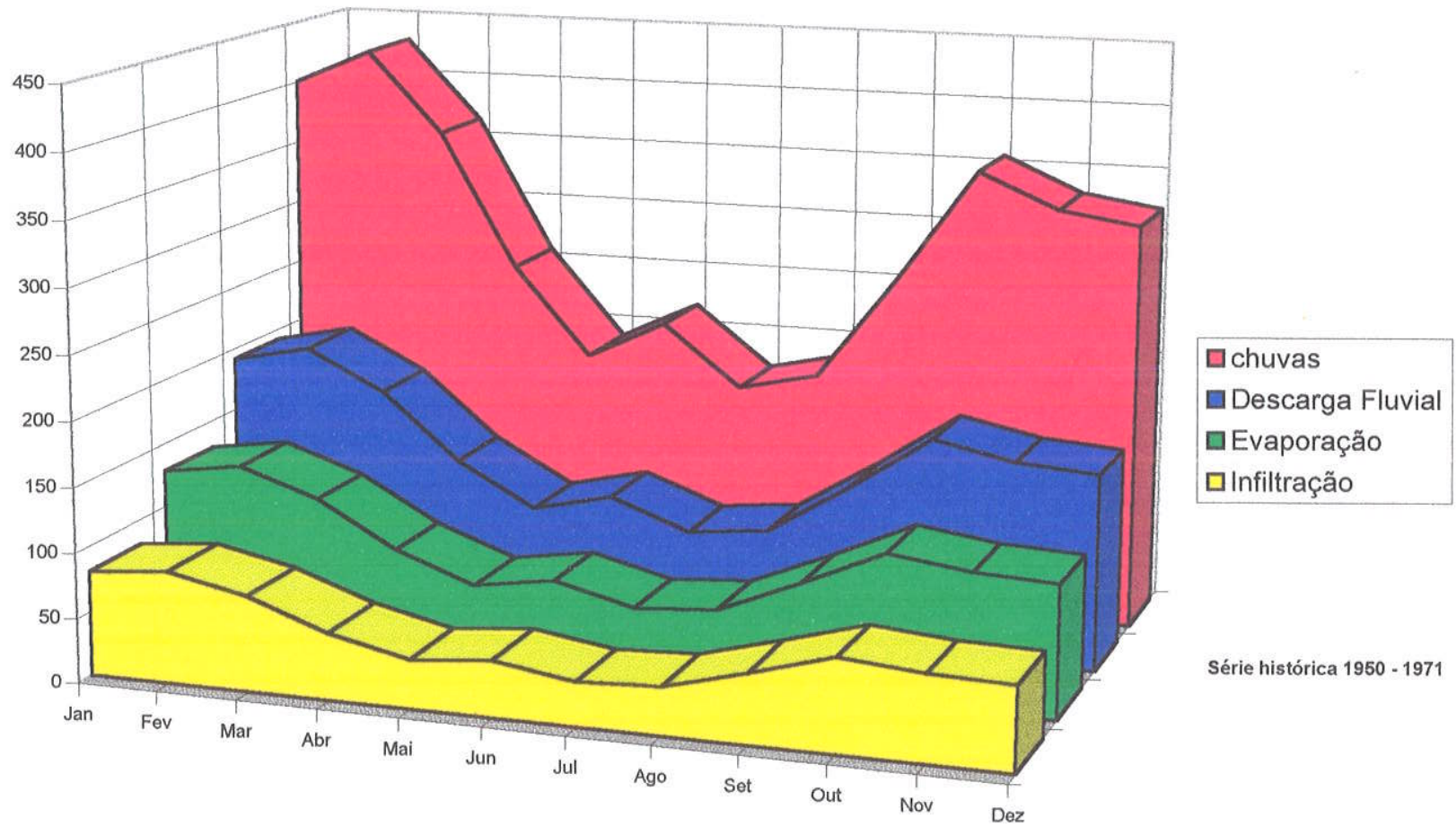

Figura 13: comportamento hídrico anual na Bacia do Rio Cubatão 
5.4 - Análise do balanço hídrico da Bacia do Rio do Júlio / Itapocuzinho:

A bacia do Rio do Júlio / Itapocuzinho situa-se no quadrante sudoeste do município e suas nascentes estão situadas na vertente da Serra do Mar. Apresenta uma área drenada total de aproximadamente $384 \mathrm{~km}^{2}$ e deságua no Rio Itapocu que é o rio principal da Bacia que recebe seu nome. Portanto o Rio do Júlio e Itapocuzinho representam uma sub bacia do Rio Itapocu.

As estações pluviométricas/fluviométricas, fontes das informações básicas estão listadas na tabela 17

tabela 17: Estações utilizadas para determinar o balanço hídrico da Bacia do Rio do Júlio/Itapocuzinho

\begin{tabular}{c|c|c|c}
\hline POSTO & CÓDIGO & SERIE HISTÓRICA & DESCRIÇÃO \\
\hline DNAEE Rio do Júlio & 0269014 & $1987-1995$ & Pluviométrico \\
\hline Rio do Júlio & 82420000 & $1987-1995$ & Fluviométrico \\
\hline
\end{tabular}

Para efeito da análise hídrica foram utilizados os valores médios mensais calculados por MIRANDA JR.(1996) a partir da série histórica 1987 a 1995 do Posto Fluviométrico DNAEE código 82420000.

\subsection{1 - Avaliação da Pluviometria}

O total acumulado anual é de $1.899,73 \mathrm{~mm}$ e uma média mensal de $158,31 \mathrm{~mm}$. A figura 14 mostra o resultado desta análise.

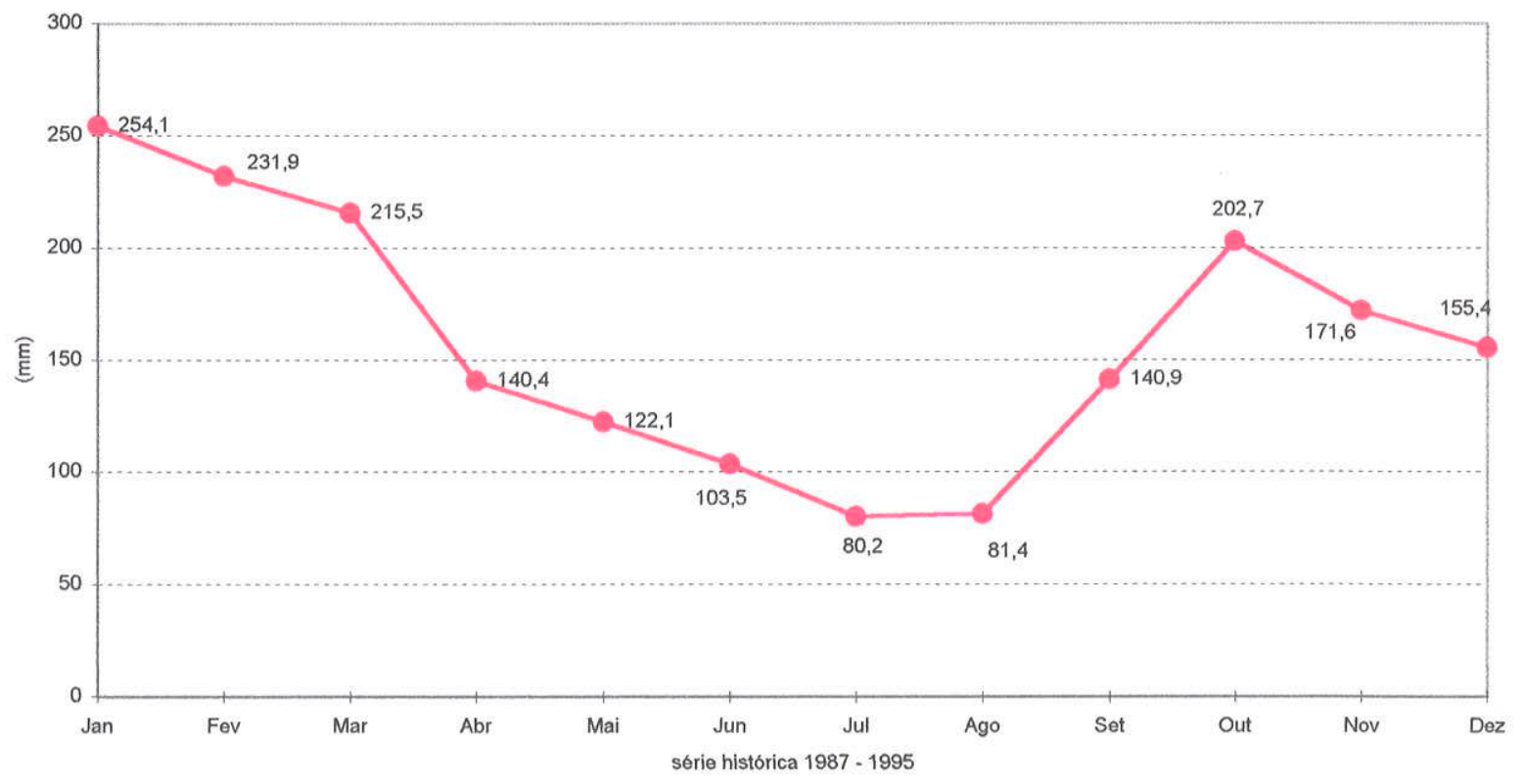

Figura 14: Variação média mensal de pluviosidade. Estação DNAEE (código 0269014) 
5.4.2 - Avaliação da descarga fluvial:

Para efetuar a análise da descarga fluvial da Bacia do Rio do Júlio foram analisadas as informações da série histórica que compreende o período de 1987 a 1995 do Posto Fluviométrico DNAEE código 82420000 . A figura 15 mostra as médias mensais $\left(\mathrm{m}^{3} / \mathrm{s}\right)$

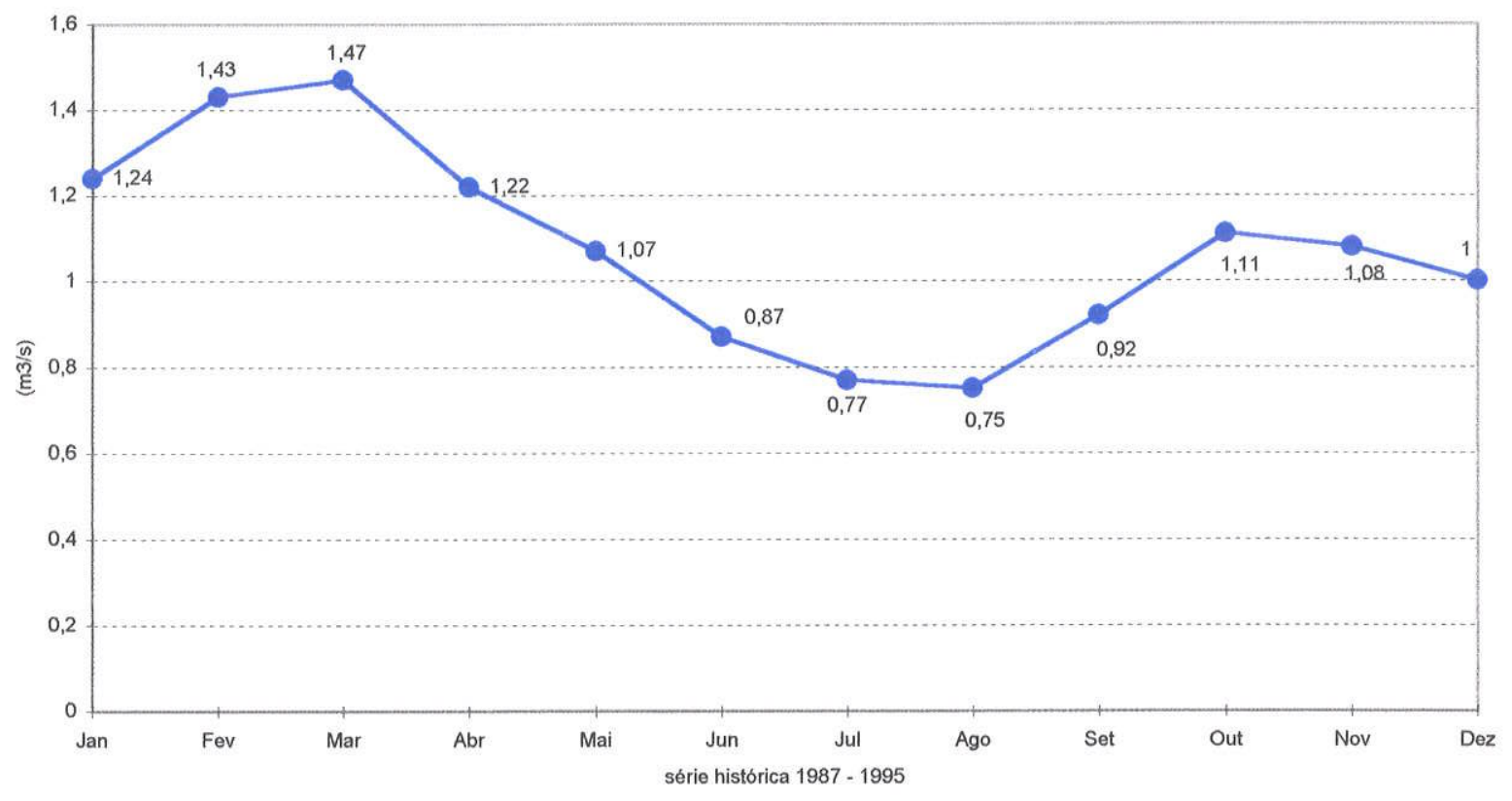

Figura 15: Variação média mensal da descarga fluvial. Estação Rio do Júlio (código 82420000)

5.4.3 - Avaliação da evapotranspiração potencial:

As informações de evapotranspiração mais próximas à Bacia do Rio do Júlio / Itapocuzinho obtidas neste estudo são aquelas da estação da Escola Técnica Tupy (Bacia do Rio Cachoeira) e estão inseridas na figura 7. 


\subsection{4 - Cálculo do balanço hídrico}

O balanço hídrico da Bacia do Rio do Júlio foi realizado a partir de uma série histórica de dados pluviométricos, fluviométricos muito curta, com problemas de dados incompletos. As informações de evapotranspiração utilizadas foram aquelas medidas pela Escola Técnica Tupy que, apesar de serem as informações mais próximas obtidas neste estudo não refletem o contexto da Bacia do Rio do Júlio. Estes fatos refletem valores inconsistentes no balanço hídrico que serão apresentados apenas para efeito ilustrativo. A tabela 18 resume estas informações:

Tabela 18: Volumes de água do balanco hídxico da Bacia do Rio do Jitio

\begin{tabular}{c|c|c} 
Balanço Hídrico & Volume & Percentual \\
\hline Pluviosidade & $1.899 .700 \mathrm{~m}^{3} / \mathrm{km}^{2} / \mathrm{ano}$ & - \\
\hline Evaporação & $401.500 \mathrm{~m}^{3} / \mathrm{km}^{2} / \mathrm{ano}$ & $2.1 .13 \%$ \\
\hline Descarga Fluvial & $1.061 .876 .25 \mathrm{~m}^{3} / \mathrm{km}^{2} / \mathrm{ano}$ & $55.90 \%$ \\
\hline Infiltracão & $436.323 .75 \mathrm{~m}^{3} / \mathrm{km}^{2} / \mathrm{ano}$ & $22.97 \%$ \\
\hline
\end{tabular}


5.5 - Análise do balanço hídrico da Bacia do Pirai:

A bacia do Rio Pirai situa-se no centro oeste do Município e apresenta área total de aproximadamente $337 \mathrm{~km}^{2}$. Suas nascentes também estão localizadas na Serra do Mar. Ao longo de seu eixo ocorrem variações granulométrica de seus sedimentos. À montante, matacões e blocos de rochas cristalinas, em seu curso médio seixos rolados com granulometria variável e a jusante, próximo a foz, areia e argila.

A tabela 19 mostra as estações utilizadas na Bacia do Rio Pirai.

Tabela 19: Estações utilizadas para determinar o balanço hídrico da Bacia do Rio Pirai.

\begin{tabular}{c|c|c|c}
\hline POSTO & CÓDIGO & SÉRIE HISTÓRICA & DESCRIÇÃO \\
\hline DNAEE Rio Pirai & 22770000 & $1977-1985$ & Fluviométrico \\
\hline $\begin{array}{c}\text { DNAEE Estrada } \\
\text { Blumenau Km 18 }\end{array}$ & --- & $1953-1987$ & Pluviométrico \\
\hline
\end{tabular}

5.5.1 - Avaliação da pluviometria

Foram utilizados os dados pluviométricos do DNAEE, estação estrada Blumenau km 18. A figura 16 mostra os resultados da análise

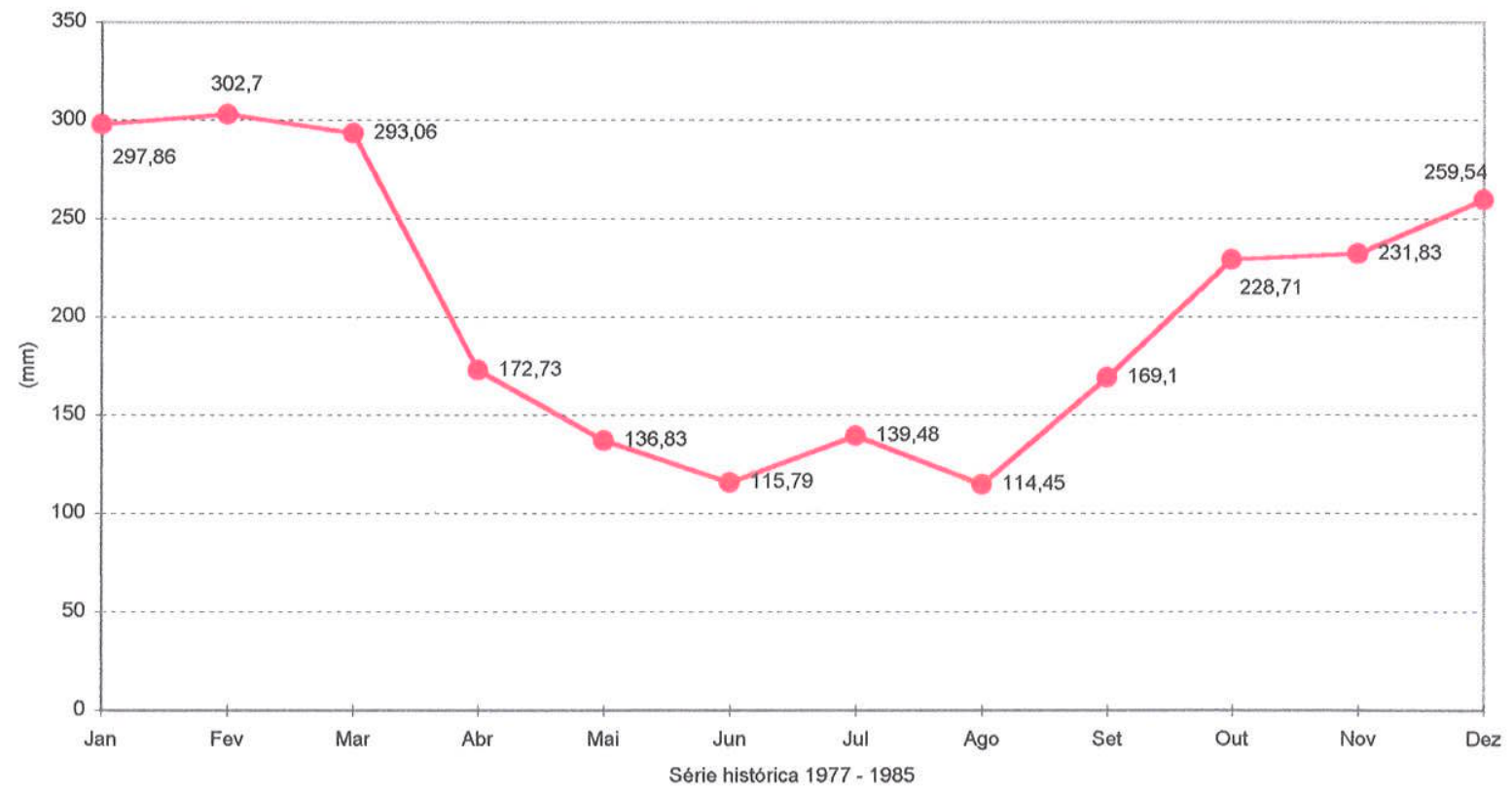

Figura 16: Variação média mensal de pluviosidade. Estação DNAEE (Estr. Blumenau Km 18)

Com base nestes dados, verifica-se que a média da precipitação mensal é de 205,17 mm. 


\subsection{2 - Avaliação da descarga fluvial}

A análise hídrica da bacia do Rio Pirai baseou-se na série histórica de 1977 a 1985 (informações fluviométricas - incompleta) do Posto Fluviométrico DNAEE código 22770000. A figura 17 , a seguir, mostra estes valores $\left(\mathrm{m}^{3} / \mathrm{s}\right)$

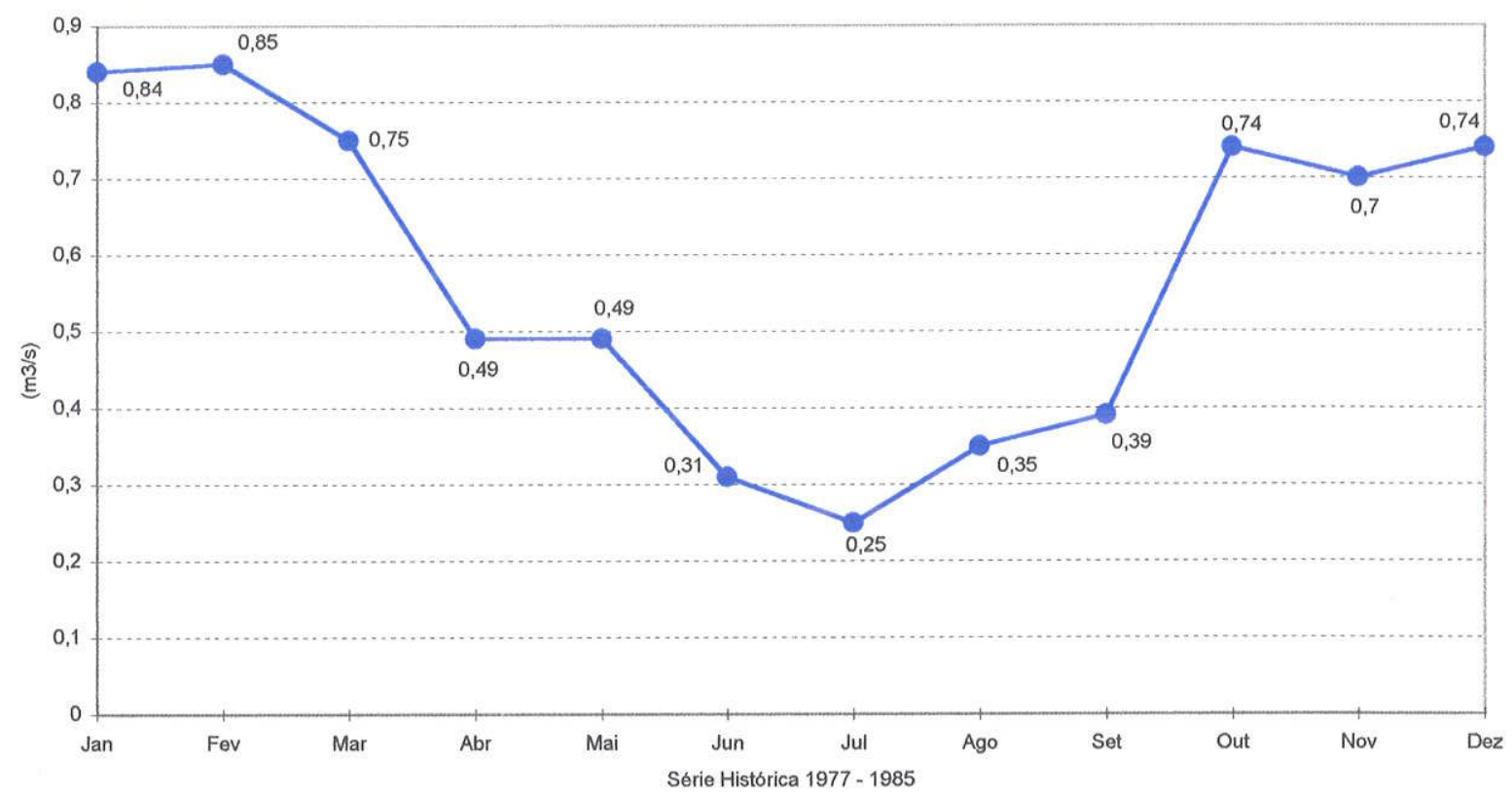

Figura 17: Variação média mensal da descarga fluvial. Rio Pirai (código 22770000)

5.5.3 - Avaliação da evapotranspiração potencial:

Os valores de evapotranspiração referentes à Bacia do Rio Pirai são aqueles definidos por GAPLAN (1986) para a cidade de Joinville. 
A figura 18, abaixo, define estes valores mês a mês (em $\mathrm{mm}$ ) e apresenta um total anual de $1077 \mathrm{~mm}$..

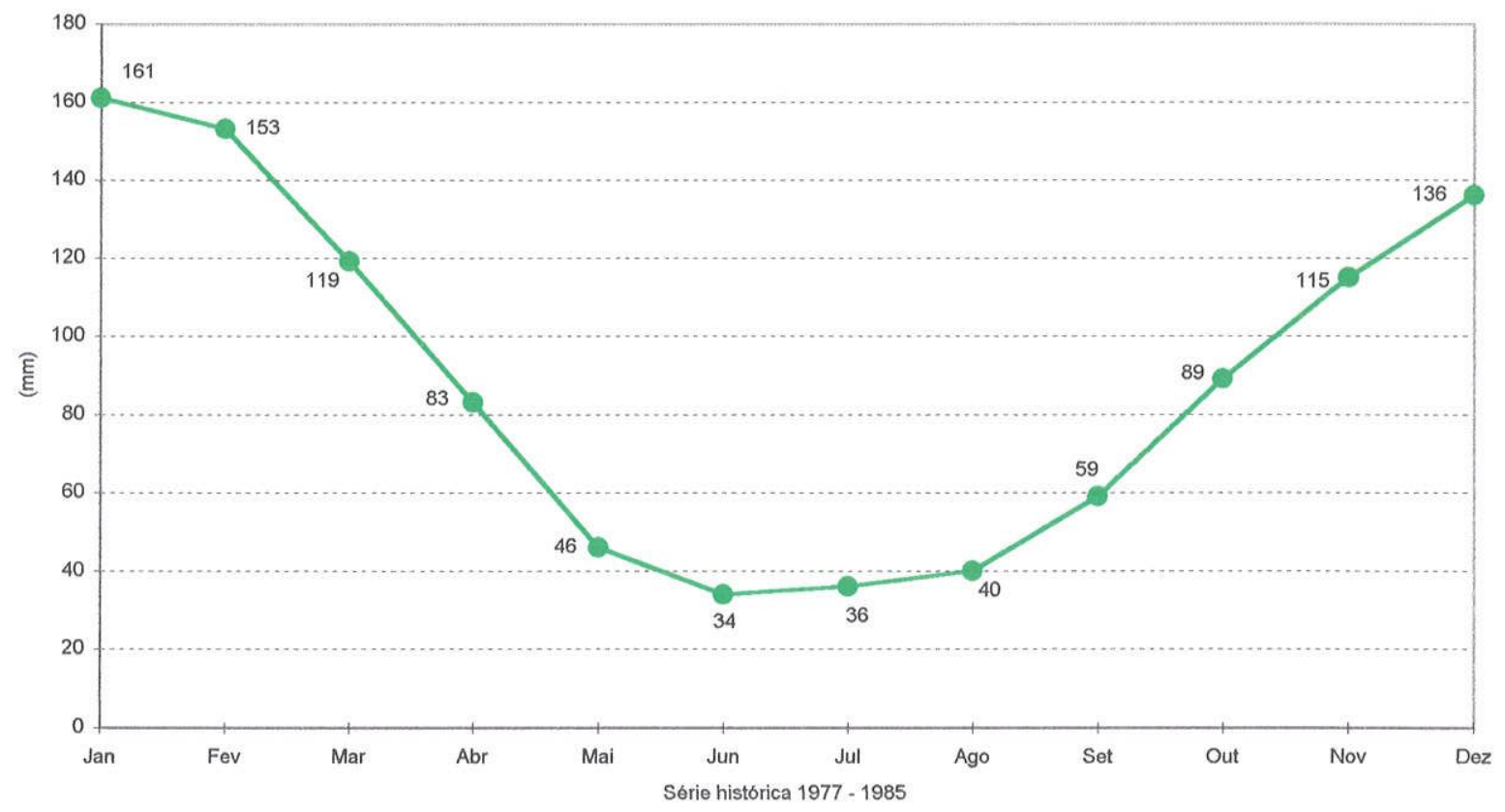

Figura 18: Variação média mensal de evapotranspiração. Gaplan (1986)

\subsection{4 - Cálculo do balanço hídrico.}

O balanço hídrico da Bacia do Rio Pirai foi realizado a partir de uma série histórica de dados pluviométricos bastante confiáveis. Por outro lado a série histórica de fluviometria é muito curta e apresenta problemas de dados incompletos. As informações de evapotranspiração utilizadas foram aquelas medidas por Gaplam para a região de Joinville e não refletem exatamente o contexto da Bacia do Rio Pirai. Estes fatos refletem valores inconsistentes no balanço hídrico, e que serão apresentados apenas para efeito ilustrativo. A tabela 20 resume estas informações:

Tabela 20: Volumes de água do balanço hídrico da Bacia do Rio Pirai.

\begin{tabular}{c|c|c}
\hline Balanço Hídrico & Volume & Percentual \\
\hline Pluviosidade & $2.462 .080 \mathrm{~m}^{3} / \mathrm{km}^{2} /$ ano & - \\
\hline Evaporação & $1.071 .000 \mathrm{~m}^{3} / \mathrm{km}^{2} /$ ano & $43.50 \%$ \\
\hline Descarga Fluvial & $645.692 .58 \mathrm{~m}^{3} / \mathrm{km}^{2} /$ ano & $26.33 \%$ \\
\hline Infiltração & $745.387 .42 \mathrm{~m}^{3} / \mathrm{km}^{2} /$ ano & $30.27 \%$ \\
\hline
\end{tabular}




\section{6. - SISTEMA AQÜIFERO FRATURADO}

\section{1 - Aspectos gerais}

O dominio hidrogeológico cristalino representa cerca de $58 \%$ do território nacional. Observa-se que, dos $5.340 .000 \mathrm{~km}^{2}$ de rochas ígneas e metamórficas aflorantes, aproximadamente $85 \%$ possuem manto de intemperismo, que chega a ter $150 \mathrm{~m}$ de espessura (CAVALCANTE e REBOUÇAS - 1990). Em Joinville este manto apresenta em média 40m.

As descontinuidades físicas das rochas que constituem os aqüiferos fraturados são geradas por processos estruturais e intempéricos. e apresentam grande diversidade de tipos. Tratam-se de falhas, fraturas, juntas, alterações químicas / dissoluções, movimentos estruturais, descompressão e outras geradas por resfriamento. $O$ aqülfero resultante destes processos é do tipo livre a semi-livre, à medida que a fratura é um prolongamento em profundidade do aqǘfero formado no manto de intemperismo.

A produtividade dos poços nas zonas aqüíferas fraturadas sem manto de intemperismo são da ordem de $3 \mathrm{~m}^{3} / \mathrm{h}$, com máximo em torno de $10 \mathrm{~m}^{3} / \mathrm{h}$. Estas vazões são pequenas, no geral, em comparação com aquelas obtidas em regiões onde o manto de intemperismo é significante, com vazôes oscilando entre 10 a $20 \mathrm{~m}^{3} / \mathrm{h}$, alcançando valores de até $70 \mathrm{~m}^{3} / \mathrm{h}$ (AGUIAR et al. 1984)

As rochas magmáticas e as metamórficas apresentam propriedades hidrogeológicas muito semelhantes. A diferença principal está na susceptibilidade ao intemperismo e no grau de fraturamento. Estas características determinam maiores ou menores vantagens hidrogeológicas. Por isso estes aqüf́feros apresentam maior probabilidade de produção nas zonas de transição próximas à superfície onde ocorrem fenômenos intempéricos, físicos e químicos.

O intemperismo sobre zonas de falhas afeta principalmente a parte superior dos pacotes líticos envolvidos, e produzem horizontes locais muito importantes para a recarga do aqüifero. Quando saturados estes horizontes compõem bons aqüúferos, como é o caso de Joinville.

Na prática percebe-se que, para a maioria dos poços perfurados em aqüíferos fraturados, não são elaborados estudos de viabilidade física, e como consequência disso, estes poços, mal locados, produzem vazões não compensatórias para o consumo humano ou para os diversos 
processos industriais. O contrário ocorre quando utilizados métodos geológicos e geofísicos para indicar as zonas com melhores características hidrogeologicas. No caso de Joinville esta avaliação será quantificada no ítem 7.4.1.

\section{2 - Aspectos hidráulicos}

Os aspectos hidráulicos discutidos neste ítem são aqueles pertinentes a permeabilidade, porosidade e regimes de fluxo de aqǘferos pesquisados por diversos autores e correlatos ao aquífero fraturado de Joinville

A permeabilidade primária das rochas ígneas e metamórficas que compõem os aquúferos fraturados é extremamente reduzida e raramente alcança $10^{-3}$ ou $10^{-4} \mathrm{~m} /$ dia. Já a permeabilidade secundária gerada pelo intemperismo e fraturamento aumenta significativamente a permeabilidade. Neste caso, fora das zonas intemperizadas, o fraturamento é o principal fator de aumento de permeabilidade.

Em rochas metamórficas e ígneas, a permeabilidade diminui rapidamente com a profundidade. Esta diminuição é um efeito combinado do peso da cobertura sobre a rocha fraturada e da tendência da superfície de descontinuidade penetrar em pequenos espaços da rocha (Davis 1966 in CUSTODIO E LLAMAS, 1976). Juntas Falhas e outras fraturas tendem a diminuir e até fechar seu espaçamento com a profundidade, devido ao peso da cobertura lítica sobre elas.

Estudos de BIEMI (1993) mostram a existência de fraturas abertas a profundidades superiores a $100 \mathrm{~m}$, com contribuição de água consideráveis. Por outro lado, o mesmo estudo mostrou que as maiores entradas de água estavam entre 20 e $60 \mathrm{~m}$ (73\% das fraturas abertas), resultado muito semelhante ao obtido neste trabalho sobre Joinville, em que as principais entradas de água estão entre 20 e $80 \mathrm{~m}(80 \%)$. Estes resultados serão comentados no ítem 7.4.6.

Os coeficientes de porosidade de aqüiferos fraturados, geralmente são aqueles obtidos em laboratório por ensaios em amostras de tamanhos reduzidos. Esta porosidade, por vezes denominada porosidade primária é pouco significativa para a pesquisa de água subterrânea uma vez que, realmente importante é a porosidade efetiva do aqüifero. No entanto esta porosidade pode apresentar grandes variações dentro do contexto de aqüifero fraturado (CUSTÓDIO E LLAMAS, 1976). 
Há três fatores principais que determinam a porosidade de aqüúferos fraturados:

- Intemperismo,

- Fraturamento, e

- Dissolução.

Destes, o principal é o intemperismo que pode multiplicar de 10 a 20 vezes a porosidade do aqüífero. Já o fraturamento aumenta muito pouco a porosidade. Segundo Davis 1966 (in CUSTÓDIO E LLAMAS, 1976) este aumento de porosidade não é superior a $5 \%$.

A porosidade diminui com a profundidade uma vez que começam a ser atingidas zonas sem alteração ou parcialmente alteradas onde somente há contribuição das fraturas e a vazão efetiva também diminui. Porém BIEMI (1993), relata aumentos consideráveis na contribuição de água em aqüíferos fraturados da Costa do Marfim, em profundidades crescentes até $70 \mathrm{~m}$, sugerindo aumentos gradativos na porosidade.

Por vezes rochas metamórficas e secundariamente igneas apresentam minerais carbonáticos que estão sujeitos a rápidas dissoluções pela água subterrânea circulante. Nestes casos, as cavidades geradas aumentam sensivelmente a porosidade local.

Para aqüiferos fraturados constituídos por rochas do embasamento cristalino, sujeitos a climas úmidos no Brasil, como é o caso de Joinville, Rebouças e Cavalcante (1987), in MENEGASSE (1991) definiram os valores de condutividade hidráulica (K) e a porosidade efetiva $\left(n_{\mathfrak{e}}\right)$ conforme descrito no quadro abaixo:

\begin{tabular}{c|c|c}
\hline Zona de interferência & Condutividade Hidráulica $(\mathrm{K})$ & Porosidade efetiva $\left(\mathrm{n}_{\mathrm{e}}\right)$ \\
\hline Zona superficial & $10^{-7}$ a $10^{-6} \mathrm{~m} / \mathrm{s}$ & 0,1 a $2,0 \%$ \\
Zona de material friável & $10^{-5}$ a $10^{-4} \mathrm{~m} / \mathrm{s}$ & 2,0 a $5,0 \%$ \\
Zona de rocha fraturada & $10^{-5}$ a $10^{-3} \mathrm{~m} / \mathrm{s}$ & - \\
\hline
\end{tabular}

Barenblatt et al 1960 (in SEKHAR, M. ET AL 1993) estudando o problema de fluxo em aqüúferos fissurados propôs o modelo de dupla porosidade onde uma rocha fissurada apresenta duas interações de fluxo sobrepostos continuamente.

A primeira, apresenta zona de baixa permeabilidade e porosidade primária. A segunda apresenta alta permeabilidade e porosidade fissural secundária. A permeabilidade secundária 
associada às fissuras é geralmente alta, considerando-se que a porosidade secundária é muitas vezes menor.

Por outro lado, os blocos são caracterizados por apresentar alto grau de armazenamento associado com baixas permeabilidades. A representação matemática deste sistema requer duas equações de conservação de massa. Estas duas equações são unidas por um termo de transferência fluido, que depende da diferença de pressão entre o bloco e o ambiente da fratura.

BLACK (1986) levantou alguns conceitos de fluxo em rochas fraturadas. Segundo ele, a regra dos testes de aqüíferos é considerada no contexto de teste de traçadores em rochas fraturadas. Isto determina que para se obter informações precisas é importante realizar teste de traçadores incluindo não somente parâmetros hidrogeológicos (transmissividade e armazenamento), mas também a geometria do fluxo.

TROISI ET ALII (1989) realizaram um estudo preliminar que analisou os aspectos da hidrodinâmica em sistemas fissurados. Sua pesquisa tratou basicamente de comparar os dados de laboratório com testes "in situ".

SEKHAR, M ET AL (1993) comenta dissertativamente que a compreensão do sistema de fluxo e armazenamento em rochas fraturadas é muito complexo. Porém propõe um modelo de dupla porosidade baseado no conceito de aqüífero fraturado anisotrópico (aquitarde).

O presente trabalho não se propôs a definir estes valores hidráulicos de permeabilidade, porosidades e regime de fluxo do aqüífero de Joinville, que deverão ser matéria de uma pesquisa científica mais aprofundada. 


\section{7. - ANÁLISE HIDROGEOLÓGICA DO AQÜÍFERO FRATURADO DE JOINVILLE}

\section{1 - Aspectos gerais}

Segundo GONCALVES E DUARTE (1996) o município apresenta dois tipos de aquuíferos. $O$ aqüífero freático, associado à zona saturada da camada de rocha alterada e aos sedimentos encontrados na área (poços rasos) e o aqüífero cristalino, associado às rochas do complexo granulítico (poços tubulares profundos)

No presente trabalho será analisado o aqüifero cristalino que corresponde aos terrenos Pré Cambrianos do Escudo Catarinense e regido principalmente pelas grandes estruturas de falhamento regional N35-50E, e apresenta as seguintes características:

- Coeficiente de retenção de água alto (o espaço interplacas micáceas funciona como armazenador de água);

- Permeabilidade superficial alta devido às ações orgânicas e microfissuras;

- Permeabilidade subsuperficial fissural (a água se instala em planos preferenciais de componentes geológicas regionais gerando regimes de fluxos subterrâneos).

- Fraturamento intenso. 


\subsection{1 - Cadastramento de poços}

Foram cadastrados 113 poços. Os parâmetros hidráulicos considerados envolveram: nível estático, nível dinâmico, vazão de exploração, rebaixamento e capacidade específica. A vazão de exploração constante é aquela calculada pelas empresas de perfuração e baseia-se na curva vazão/rebaixamento obtida nos testes de vazão dos poços.

Como informações hidrogeológicas foram inseridas no banco de dados a localização geográfica, o perfil litológico completo, a profundidade final, as profundidades de entradas de água e as espessuras do manto.

As informações complementares foram: ano de perfuração, empresas perfuradoras e todas as informações construtivas.

Os poços cadastrados estão localizados em cotas muito próximas ao nível do mar, variando em média entre 3 e $20 \mathrm{~m}$. Esta característica demonstra que a qualidade da água é um dos indicativos mais fortes nas áreas com influência de maré, que apresentam altas concentrações de cloretos.

O resultado do cadastramento de 113 poços para abastecimento das indústrias e hotéis de Joinville está descrito no Anexo III, sendo que destes $88 \%$ são produtivos (a partir de $1 \mathrm{~m}^{3} / \mathrm{h}$ ) e $12 \%$ foram considerados improdutivos. 


\subsection{2 - Histórico das perfurações}

Durante o período de 1970 até 1985 a perfuração dos poços em Joinville estava ligada às grandes unidades industriais como exemplos a Cônsul (Multibrás) e a Tigre e era interpretada como investimento de alto risco. Neste mesmo período houve a sancionamento da Lei Municipal número 1.284 de 23/06/73 que estabeleceu convênio entre a Prefeitura Municipal de Joinville e a CASAN (Cia. Catarinense de Água e Saneamento), que passou a gerenciar os serviços de água e esgotos. Foram feitos grandes investimentos em novas captações de água de superfície e novas adutoras, o que ofereceu ao mercado Joinvilense água em grande quantidade, de boa qualidade e com custo razoável.

A partir de 1986, com o Plano Cruzado, novas empresas foram economicamente incentivadas a estabelecer-se no município. A Indústria do Turismo dava seus primeiros passos, motivada principalmente, pelas festas regionais (Oktoberfest, Fenachopp, Fenarreco e outras) e muitos hotéis e similares se instalaram na cidade. Para absorver todo este mercado potencial, muitos poços tubulares foram perfurados e os resultados obtidos incentivaram novos poços.

De 1986 a 1995 (10 anos) foram perfurados $72 \%$ dos poços existentes e somente em 1996 os poços perfurados atingiram praticamente $10 \%$ do total já perfurado na cidade.

A figura 19 demonstra e evolução das perfurações desde 1970.

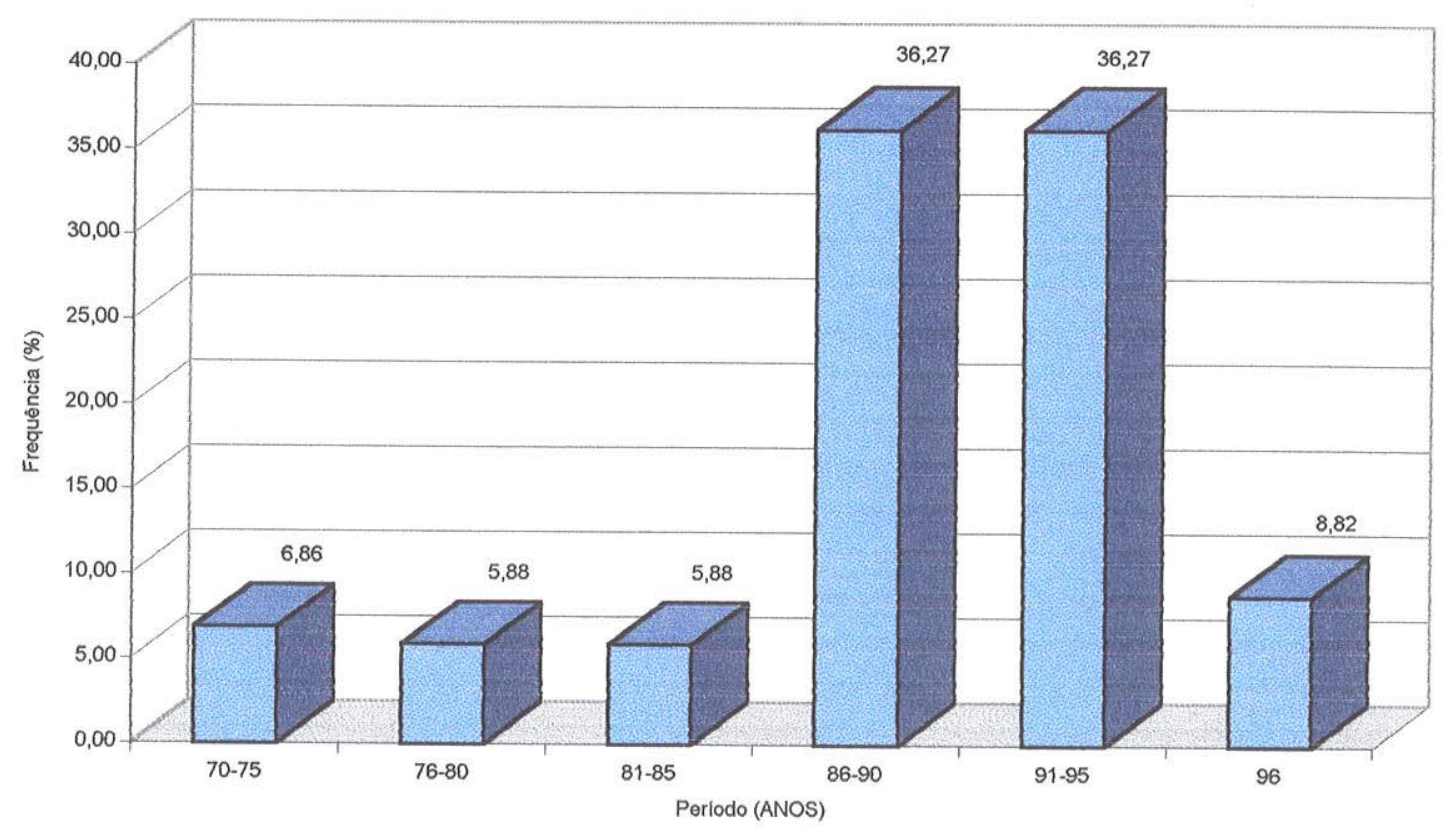

figura 19: Frequência das perfurações executadas no período de 1970 a 1996 (102 poços) 


\section{2 - Aspectos físicos}

\subsection{1 - Profundidades do manto de intemperismo}

Conforme já descrito as litologias predominantes em Joinville são os gnaisses, sempre associados a outras litologias de menor expressão. Os minerais que mais se destacam são o quartzo, feldspatos, muscovita e biotita. Os últimos quando associados a climas úmidos geram perfis de alteração a partir da hidratação e hidrólise formando argilo minerais.

As maiores profundidades de regolito encontradas giram em torno de 30 a 40m (21\%), foi constatada a profundidade de 86m na BR 101 (Posto Ego) informação desconsiderada para este estudo, uma vez, que a interpretação final definiu-a como valor anômalo. À estas áreas estão associadas as intensas linhas estruturais de ruptura e contatos litológicos que definem as linhas de fluxo e a complexidade do aqüífero bem como facilitam a interação água rocha e promovem as alterações químicas (MENEGASSE, L.N 1991).

O desenvolvimento do espesso manto de intemperismo sobre as Rochas do Complexo Cristalino em Joinville está ligado a três fatores:

- Clima quente e úmido,

- Alta taxa de pluviosidade e

- Predominância de litologia com constituição mineralógica alumino silicática.

A figura 20 mostra a frequência das espessuras do manto de alteração.

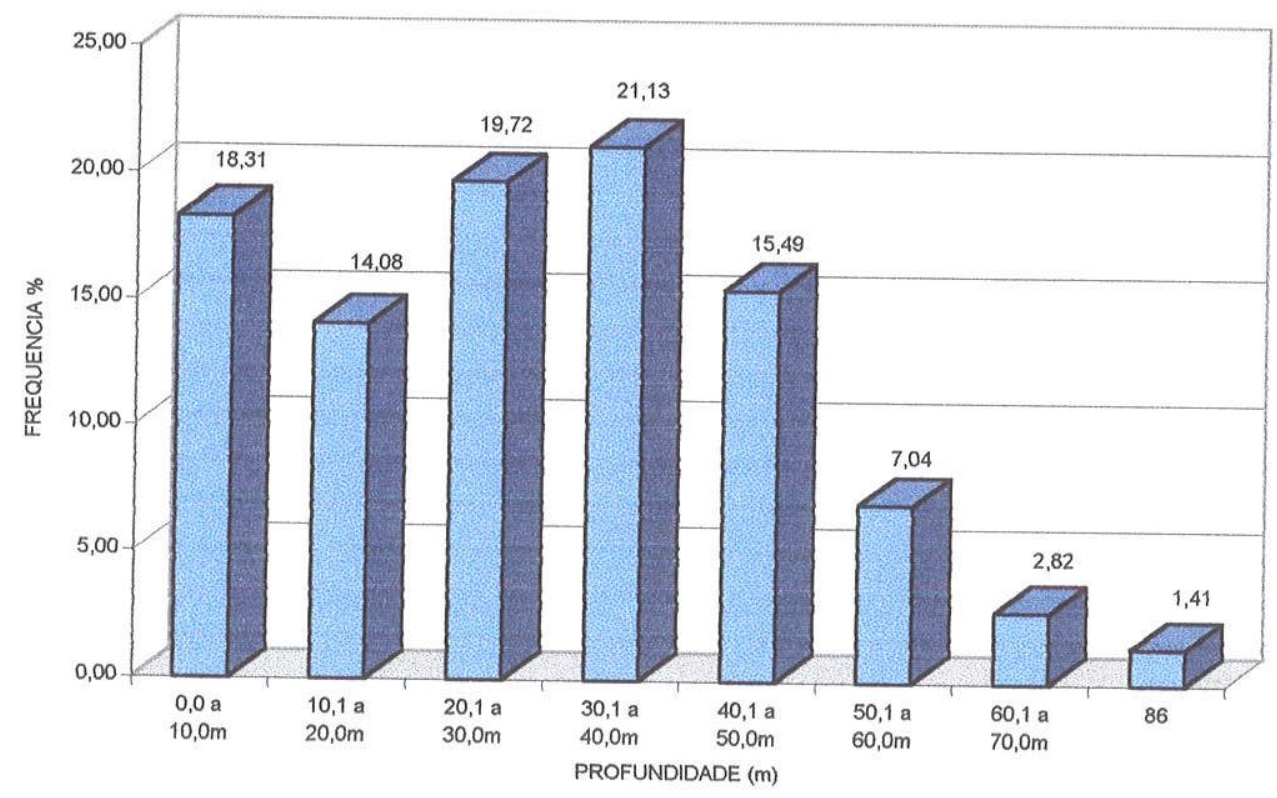

Figura 20: Frequência das espessuras do manto intemperizado (71 poços) 


\subsection{2 - Profundidades dos poços tubulares}

A grande maioria dos poços perfurados na cidade de Joinville apresentam profundidades entre $100 \mathrm{~m}$ e $130 \mathrm{~m}$ (62\%). 13\% correspondem à poços com menos de $100 \mathrm{~m}$ e $16 \%$ correspondem à poços com profundidades superiores, que variam de $130 \mathrm{a} 160 \mathrm{~m}$. Apenas $3 \%$ dos poços apresentam profundidades superiores a $160 \mathrm{~m}$. A figura 21 mostra a frequência das profundidades dos poços tubulares profundos.

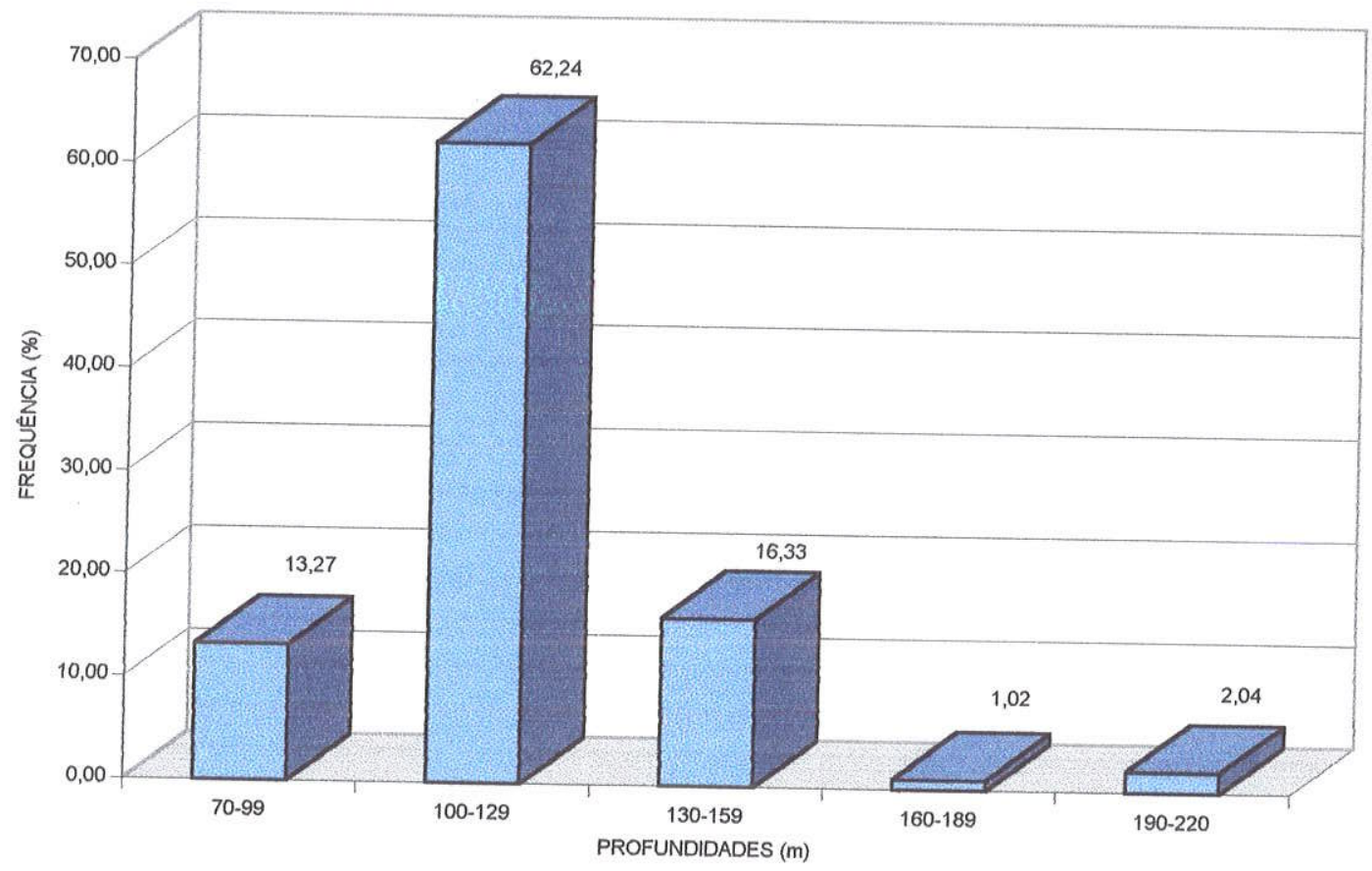

figura 21: Frequência das profundidades dos poços (98 poços)

\section{3 - Aspectos construtivos}

A análise dos aspectos construtivos dos poços tubulares para este estudo, seguiu as normas NB 588 - Projeto de poço para captação de água subterrânea (ABNT 1990a) e NB 1290 construção de poço para captação de água subterrânea da ABNT(1990b)

Foram avaliados os diâmetros de perfuração, revestimento, instalação de filtros e cimentação do espaço anular para proteção sanitária. 


\subsection{1 - Perfuração}

No que diz respeito à perfuração dos poços, foram utilizados os métodos convencionais de mercado: o método rotativo/percussão (60\% dos poços) e, o método Rotopneumático (40\%), que tem uma melhor performance e atinge os objetivos em menor espaço de tempo ( 3 ou 4 dias para poços de até $150 \mathrm{~m})$.

Observa-se que os poços mais antigos foram perfurados com sistema a percussão enquanto que a maior parte dos poços mais recentes foram perfurados pelo sistema rotopneumático.

A análise das perfurações dos poços em Joinville mostrou que $57 \%$ deles foram iniciados com diâmetros nominais de perfuração em torno de 10 polegadas $(25,4 \mathrm{~cm}), 16 \%$ em torno de 12 polegadas $(30,48 \mathrm{~cm})$ e $13 \%$ em torno de 8 polegadas $(20,32 \mathrm{~cm})$. A figura 22 mostra todas as frequências registradas no estudo.

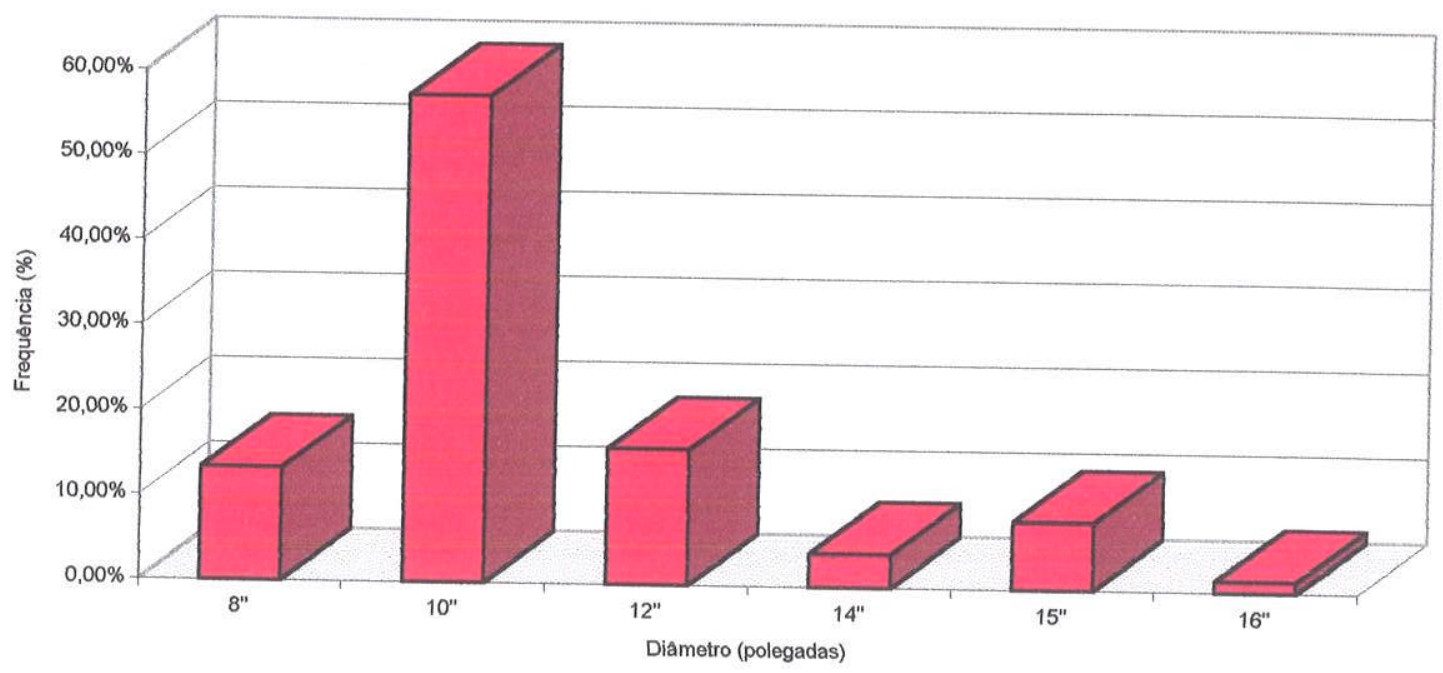

Figura 22: Frequência dos diâmetros iniciais das perfurações (75 poços) 
7.3.2 - Instalação de colunas de revestimento e seções de filtro

No que diz respeito ao diâmetro nominal útil, o estudo revelou que $93,4 \%$ dos poços apresentam revestimento em torno de 6 polegadas $(15,24 \mathrm{~cm}), 4 \%$ em 4 polegadas $(10,16 \mathrm{~cm}) \mathrm{e}$ $2,6 \%$ em 8 polegadas $(20,32 \mathrm{~cm})$ conforme mostra a figura 23.

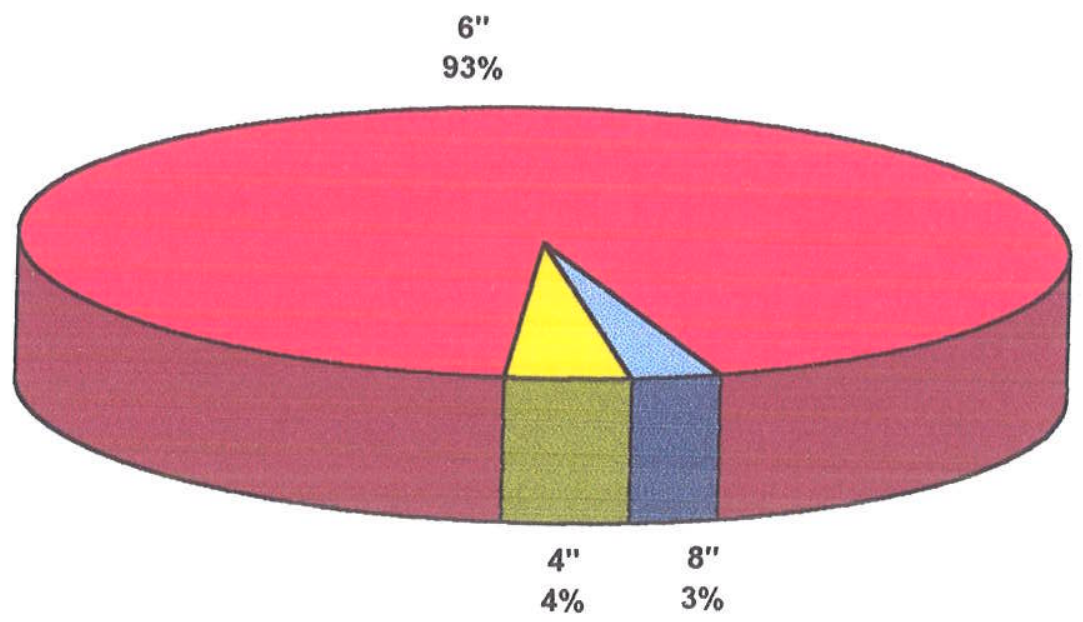

Figura 23: Frequência dos diâmetros úteis.(Em polegadas. 75 poços).

A especificação do revestimento é um dos itens muitas vezes não informado. Entretanto as poucas informações registradas mostram o uso de tubos tipo DIN 2440 ou tubo preto de Ferro Galvanizado geralmente com as extremidades unidas por pontos de solda, o que neste caso, foge das especificações constantes nas normas da ABNT, e podem apresentar infiltrações pela corrosão no revestimento, como será analisado a seguir.

Com relação à instalação de seções de filtros, a primeira análise constatou que 73,3\% dos poços apresenta seções de filtro e 26,7\% não apresentam seções de filtro.

Para estes $73,3 \%$ que apresentam filtros foi realizada uma análise mais criteriosa, no sentido de avaliar a profundidade de instalação dos filtros e sua real necessidade.

As maiores frequências de instalação de colunas de filtros estão entre 20-40m (45\%) e 41-60m (29\%). 
O resultado completo da análise está sintetizado na figura 24 a seguir:

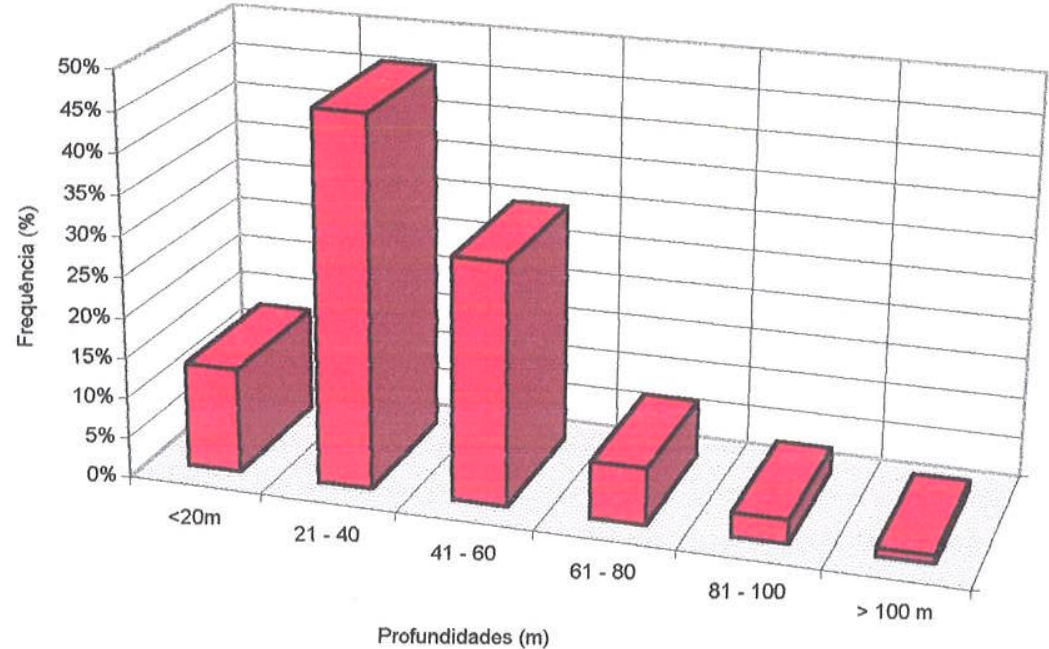

Figura 24: Frequência dos intervalos de instalação dos filtros (75 poços)

O objetivo desta análise, na verdade, foi avaliar o aproveitamento das entradas de água do aqüífero.

Como no aqüífero fraturado a passagem de água se dá diretamente através de entradas de água (fendas, fraturas e fissuras da rocha), percebe-se, comparativamente, que há uma boa correlação e um bom aproveitamento das entradas de água (figura 25).

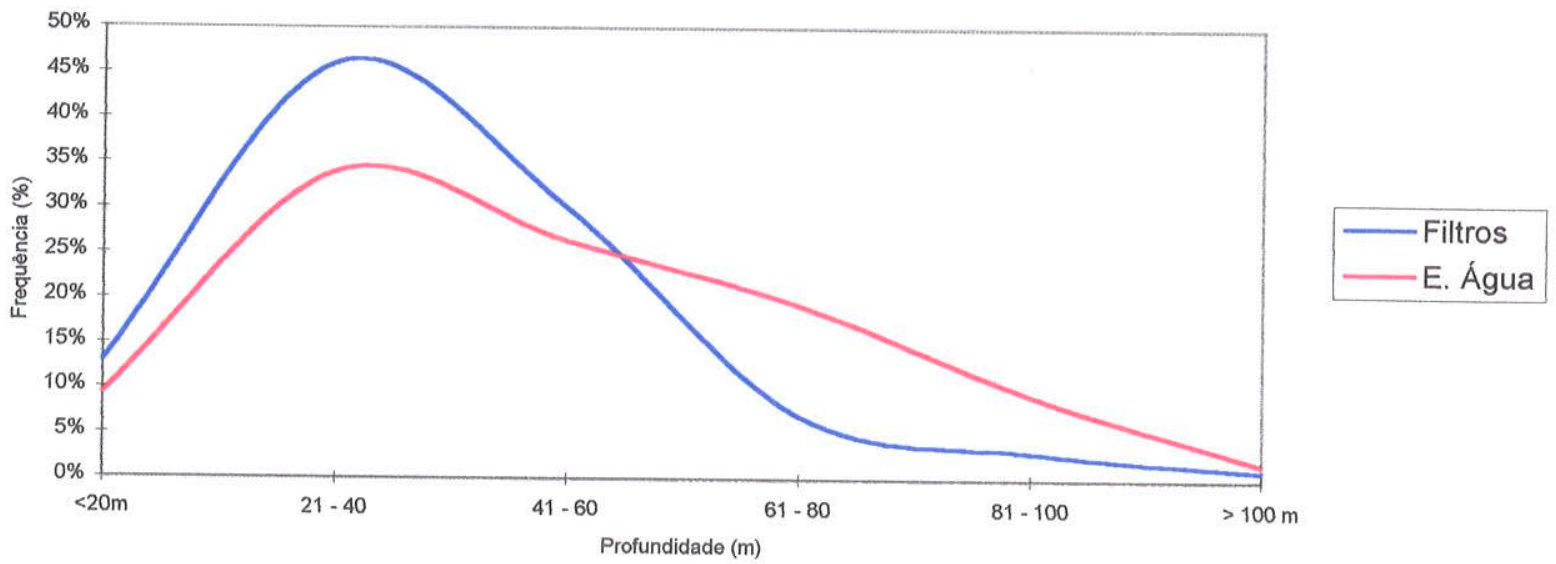

Figura 25: Entradas de água x Instalação de filtros ( 75 poços) 
Nas entradas de água mais superficiais, onde a possibilidade de turbidez e poluição é grande, a possibilidade de instalação de filtros passa pela seguinte análise. Se a utilização da água for para fins industriais, a instalação de pré-filtro e de filtros é benéfica. Porém se for para consumo humano estas entradas de água não devem ser utilizadas.

Por outro lado, a instalação de filtros acima de $61 \mathrm{~m}$ é na sua maioria muito mais função de venda do que, de técnica para facilitar ou preservar a produção do poço. Pelo contrário, muitas vezes prejudica a produção.

\subsection{3 - Problemas em colunas de revestimento e filtros}

Os problemas mais comuns como obstrução das colunas de revestimento e filtros, refletem-se diretamente na qualidade da construção do poço. Já os aspectos relacionados à corrosão e incrustação estão ligados mais ao quimismo da água, porém são acelerados quando a construção do poço é feita com materiais impróprios ou desenvolvida fora das normas. Exemplos práticos são o uso da solda para unir extremidades de colunas. Neste caso a corrosão atacará exatamente o local soldado.

A condutividade elétrica (CE) está diretamente relacionado ao teor de sólidos totais dissolvidos (STD) na água (item 7.6). Qualquer incremento de STD é um acelerador da corrosão, que se torna severa quando este parâmetro é superior a $1000 \mathrm{mg} / \mathrm{L}$. A condição está também associada ao aumento do teor de cloretos, notadamente em áreas litorâneas, como é o caso de Joinville, o que aumenta a probabilidade de corrosão.

Como efeitos diretos da ação destes agentes percebe-se:

- aumento da turbidez da água, provocada pelo colapso de seções de filtro (em poços antigos) ou como resultado de desenvolvimento insuficiente durante a construção (poços novos).

- queda da Vazão,

- produção de areia,

- deterioração da estrutura do poço,

- defeitos no equipamento de bombeamento, entre outros.

A tabela 21 mostra os problemas relacionados a colunas de revestimento e filtros. 
Tabela 21: Problemas em revestimentos e filtros

\begin{tabular}{|c|c|c|}
\hline OBSTRUÇÃO & AÇÃO CORROSIVA & AÇÃO INCRUSTANTE \\
\hline $\begin{array}{l}\text { Rebaixamento } \\
\text { progressivo do Nivel } \\
\text { dinâmico. Pouca } \\
\text { mudança no nível } \\
\text { estático. } \\
\text { Queda de Vazão. }\end{array}$ & $\begin{array}{ll}\text { - } & \mathrm{pH}<5 \\
\text { - } & \mathrm{OD}>2 \mathrm{mg} / \mathrm{L} \\
\text { - } & \text { Presença } \mathrm{H}_{2} \mathrm{~S} \\
\text { - } & \mathrm{STD}>1000 \mathrm{mg} / \mathrm{L} \\
\text { - } & \mathrm{CO}_{2}>50 \mathrm{mg} / \mathrm{L} \\
\text { - } & \mathrm{Cloretos}>300 \mathrm{mg} / \mathrm{L} \\
\end{array}$ & $\begin{array}{ll}\text { - } & \mathrm{pH}>8 \\
\text { - } & \text { Dureza } \geq 300 \mathrm{mg} / \mathrm{L} \\
\text { - } & \text { Ferro } \geq 2 \mathrm{mg} / \mathrm{L} \\
\text { - } & \text { Manganês a } \mathrm{pH} \geq 8: 1 \mathrm{mg} / \mathrm{L}\end{array}$ \\
\hline
\end{tabular}

\subsection{4 - Cimentação do espaço anular para proteção sanitária}

A cimentação para proteção sanitária compreende o processo de vedação de qualquer espaço anular com argamassa ou pasta de cimento (NB 1290) ou seja o isolamento do espaço entre a boca do poço e a profundidade desejada no espaço anular para o qual se deseja isolar as águas superficiais.

Em Joinville as profundidades impermeabilizadas variam de $5 \mathrm{~m}(35 \%)$ a até superiores a $50 \mathrm{~m}(10 \%)$. anular.

A figura 26 mostra a frequência e a distribuição das espessuras de cimentação do espaço

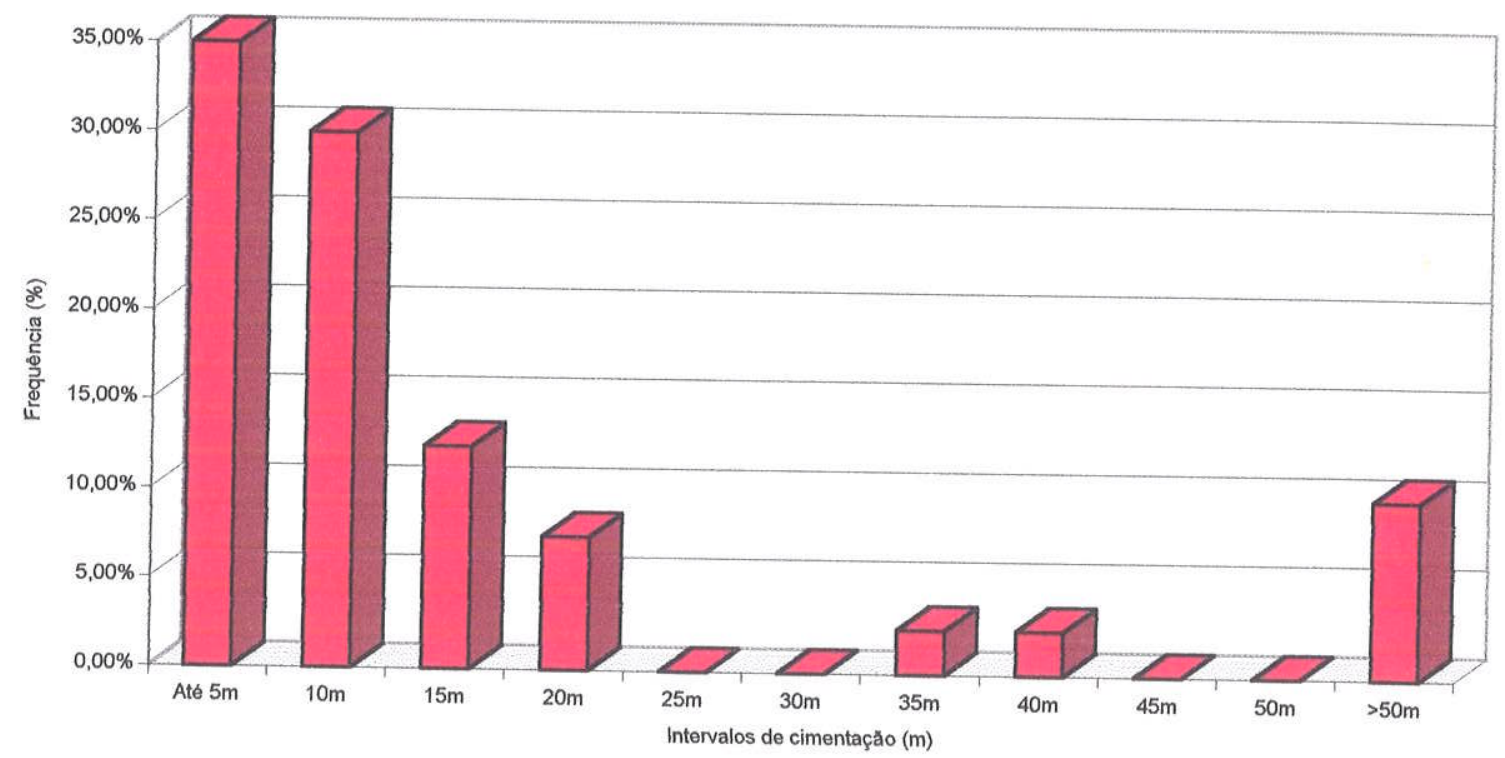

Figura 26 - Frequência da profundidade da cimentação do espaço anular (40 poços)

Com relação à espessura da cimentação, a norma brasileira NB 1290, prevê que a cimentação para proteção sanitária, deve apresentar espessura mínima de $5 \mathrm{~cm}$. Em Joinville a espessura da cimentação dos poços é na sua maioria em $5,08 \mathrm{~cm}$ e por vezes $10,16 \mathrm{~cm}$, dentro da norma brasileira. 


\section{4 - Hidráulica dos poços}

\subsection{1 - Vazões}

A análise das frequências das vazões mostrou que as maiores concentrações de produção estão em torno de 1 a $3 \mathrm{~m}^{3} / \mathrm{h}$ (24\% dos poços). Conforme esta mesma análise a produção dos poços decai com o aumento da profundidade.

Os poços mais profundos $(180 \mathrm{~m}, 200 \mathrm{~m}$ e $218 \mathrm{~m})$ mostraram vazões de $14,0 \mathrm{~m}^{3} / \mathrm{h}$, $4,5 \mathrm{~m}^{3} / \mathrm{h}$ e $4,5 \mathrm{~m}^{3} / \mathrm{h}$ respectivamente. No poço de $180 \mathrm{~m}$ que apresentou vazão de $14,0 \mathrm{~m}^{3} / \mathrm{h}$ constatou-se que as contribuições de água situavam-se entre 25 e $40 \mathrm{~m}$ e aos $80 \mathrm{~m}$, portanto nestes poços não foi constatado o aumento de vazão, com o aumento da profundidade.

Em Joinville a média geral apresenta vazões da ordem de 1 a $3 \mathrm{~m}^{3} / \mathrm{h}$. Estes valores refletem a falta de critérios técnicos utilizados para locar os poços. Inferiu-se que $81,4 \%$ dos poços tubulares de Joinville não tiveram estudos preliminares. 8,8\% utilizaram critérios básicos de locação (análise simples de fotografias aéreas) e resultaram em vazões entre 9 e 15 $\mathrm{m}^{3} / \mathrm{h}$. Porém quando efetuados estudos hidrogeológicos $(5,8 \%$ dos poços), foram obtidas vazões entre 15 e $25 \mathrm{~m}^{3} / \mathrm{h}$ (poços 19, 24, 26, 36, 44, 52, 61, 66, 81, 88, 92 e 106)

A figura 27 mostra a frequência das vazões.

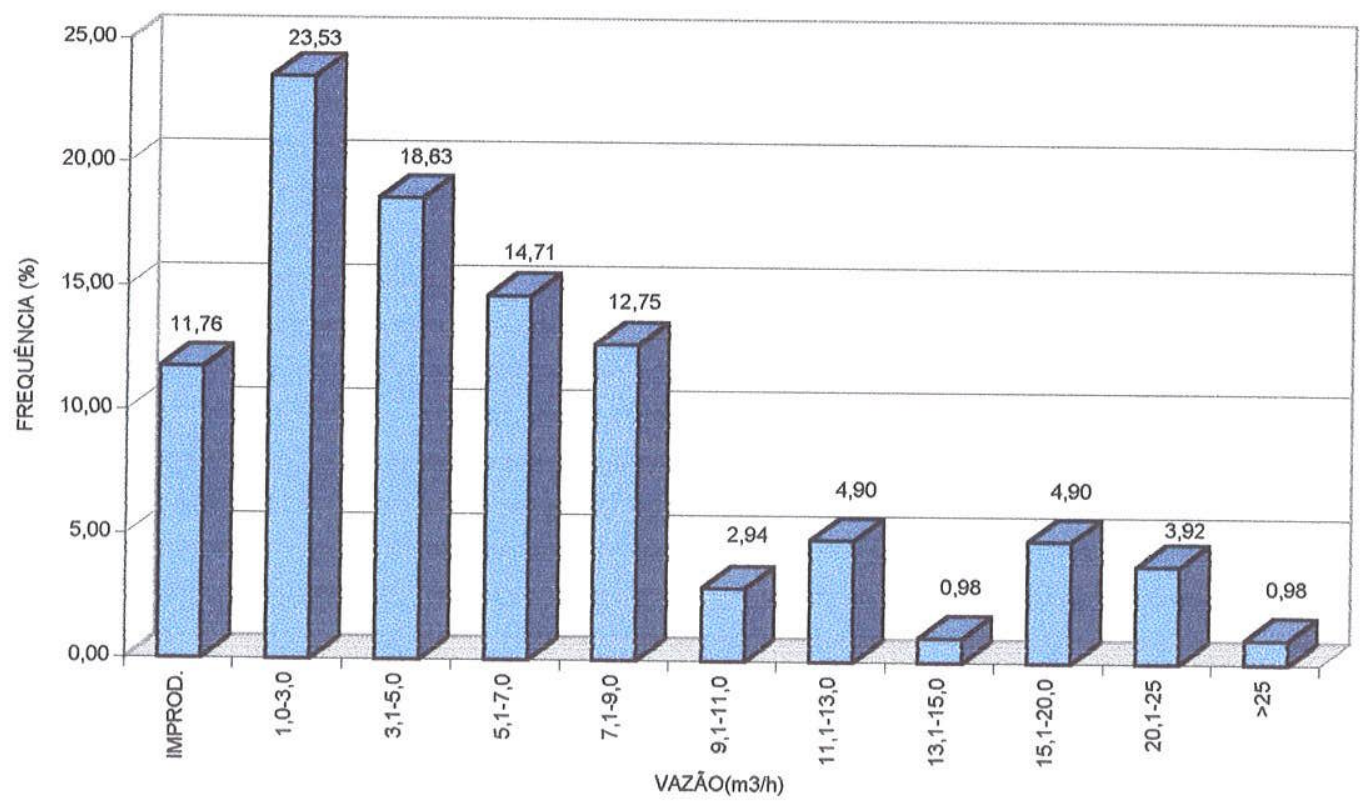

Figura 27: Frequência das vazões (112 poços) 


\subsection{2 - Nível estático}

O comportamento do nível estático (NE) em aqüíferos fraturados depende de diversos fatores como porosidade, permeabilidade, fluxo subterrâneo e principalmente da proximidade das zonas de recarga e o número de fraturas abertas que disponibilizam a água subterrânea para o aqüífero.

No caso específico do aqüífero fraturado de Joinville, o NE varia de $0,7 \mathrm{~m}$ (poço 66) a 36 $\mathrm{m}$ (poço 67), sendo que a maior frequência (61\%) está em torno de 0,7 a $6 \mathrm{~m}$, conforme pode ser observado na fig. 28 abaixo:

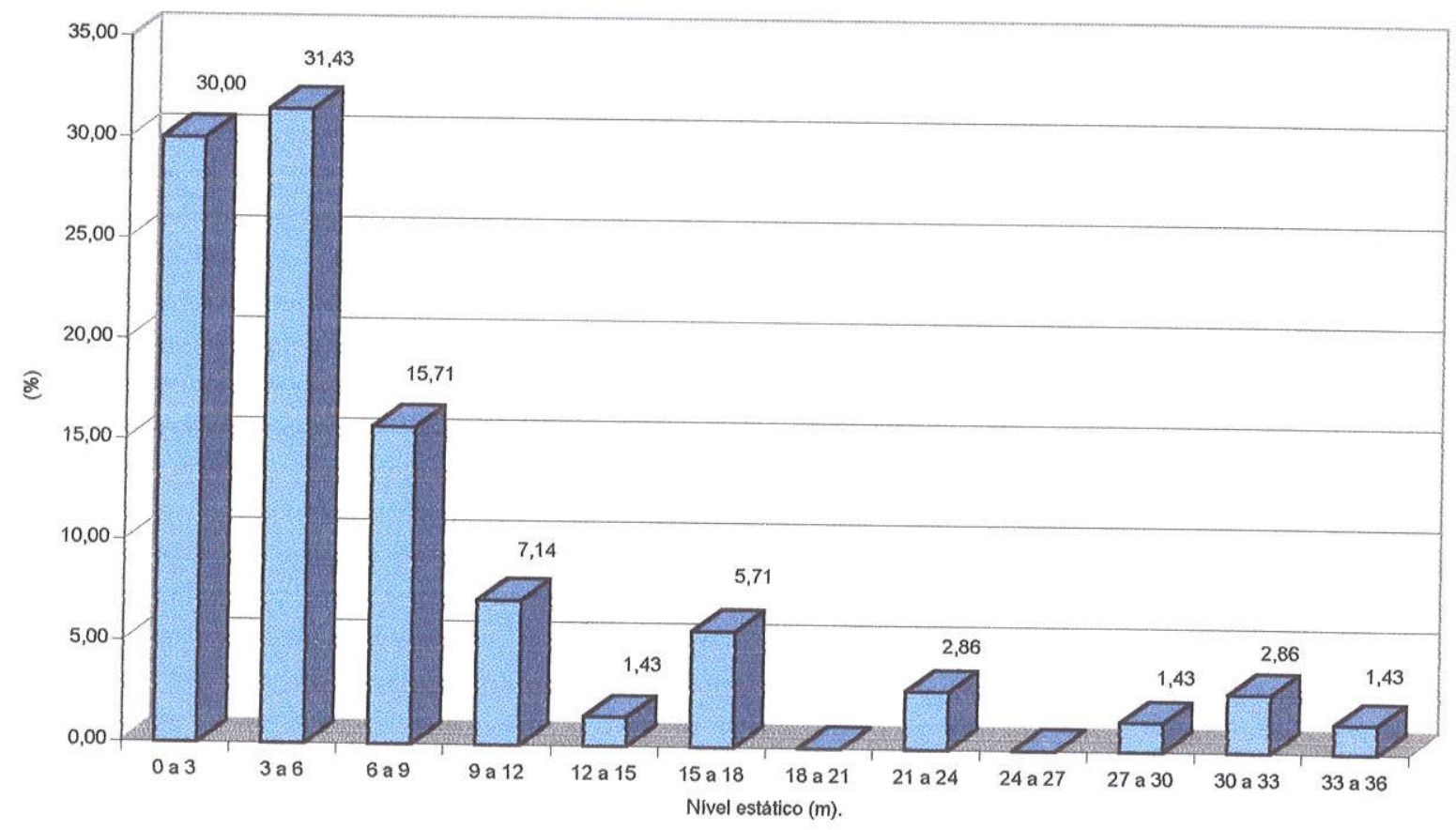

Figura 28 - Frequência do nível estático dos poços tubulares profundos (70 poços)

7.4.3 - Rebaixamentos do nível estático

Os rebaixamentos observados após o teste de vazão (12h a 36h) estão em torno de 30 a $50 \mathrm{~m}(38 \%)$, porém ocorrem ainda rebaixamentos da ordem de $130 \mathrm{~m}$, associados a zonas de baixa produtividade e baixa recarga. Os menores rebaixamentos observados foram aqueles dos poços $96(19 \mathrm{~m}), 71(16 \mathrm{~m}), 52(11 \mathrm{~m})$ e $70(10 \mathrm{~m})$ que estão associados a poços locados sobre 
lineamentos e próximos a áreas de recarga. A figura 29 mostra a distribuição destas frequências.

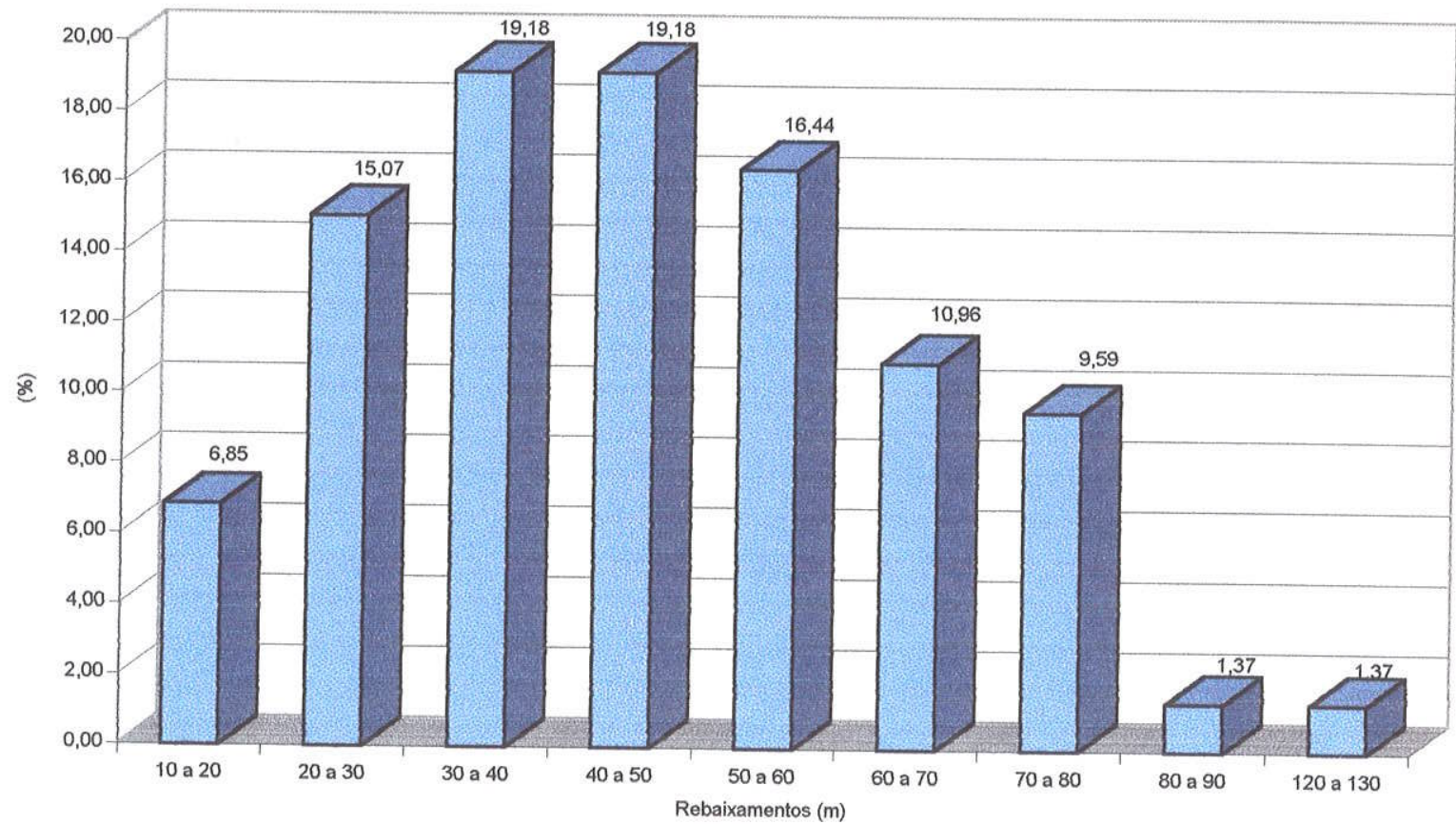

Figura 29 - Frequência do rebaixamento de nível (73 poços)

\subsection{4 - Nível dinâmico}

Por consequência dg rebaixamento, os níveis dinâmicos mais profundos foram aqueles constatados nos poços 31 (138m), 8 (90m), 34 (80m), 95 (75m) e 3 (70m). As frequências dos níveis dinâmicos estão distribuídas conforme mostra a figura 30 .

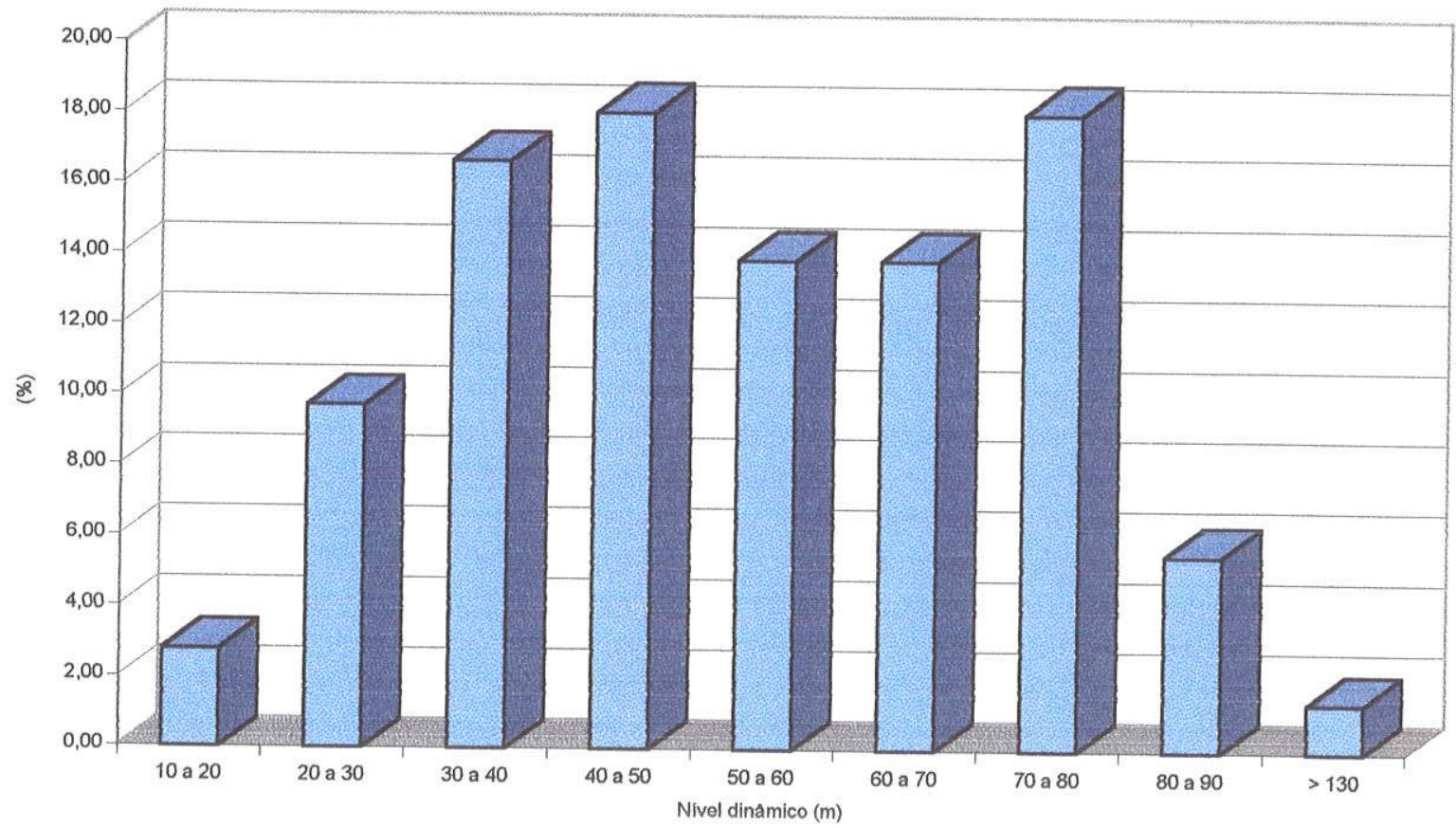

Figura 30: Frequência do nível dinâmico dos poços tubulares profundos (72 poços) 


\subsection{5 - Capacidade específica}

As capacidades específicas, calculadas a partir das informações cadastradas neste trabalho, apresentam valores extremamente baixos. 90\% das ocorrências apresentam valores até $0,5 \mathrm{~m}^{3} / \mathrm{h}$.m. $7 \%$ variam de 0,5 a $1,0 \mathrm{~m}^{3} / \mathrm{h}$.m e apenas $3 \%$ estão acima de $1,0 \mathrm{~m}^{3} / \mathrm{h} . \mathrm{m}$.

Estes valores, embora retirados do aqüífero fraturado e portanto, com pouca consistência, refletem a falta do planejamento na locação da grande maioria dos poços. Devido a estas características foram utilizados apenas como referências na avaliação das áreas mais promissoras dentro do aqüífero e não como indicadores para locações.

A figura 31 mostra a frequência dos valores de capacidade específica.

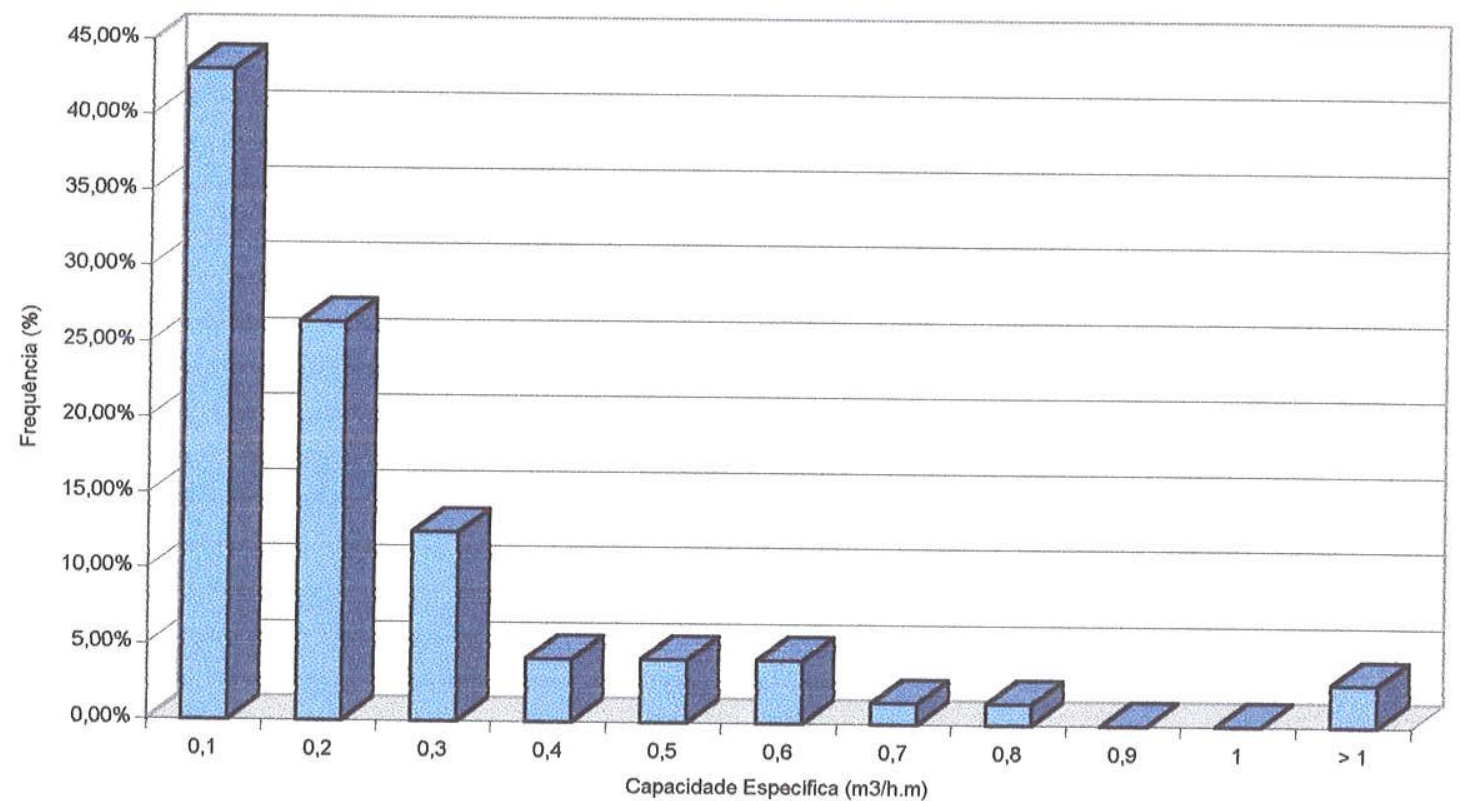

Figura 31: Frequência dos valores de capacidade específica ( 72 poços)

\subsection{6 - Profundidade das entradas de água}

Praticamente $90 \%$ das entradas de água estão em profundidades entre 20 e $100 \mathrm{~m}$ e com certeza este é o motivo da grande maioria dos poços apresentarem variação de 100 a $130 \mathrm{~m}$ e representaram mais de $90 \%$ das vazões produzidas. Por outro lado, verifica-se que até os $40 \mathrm{~m}$ de profundidade estão as maiores concentrações de entradas de água (34\%), o que caracteriza 
a recarga pluvial como principal fonte do sistema e define a zona do manto como principal contribuinte.

A análise mostrou ainda que a partir dos $40 \mathrm{~m}$ as entradas de água diminuem sensivelmente com o aumento da profundidade. Isto mostra que a maior parte das contribuições de água situam-se na zona de alteração e fraturamento.

A figura 32 mostra a frequência das profundidades das entradas de água.

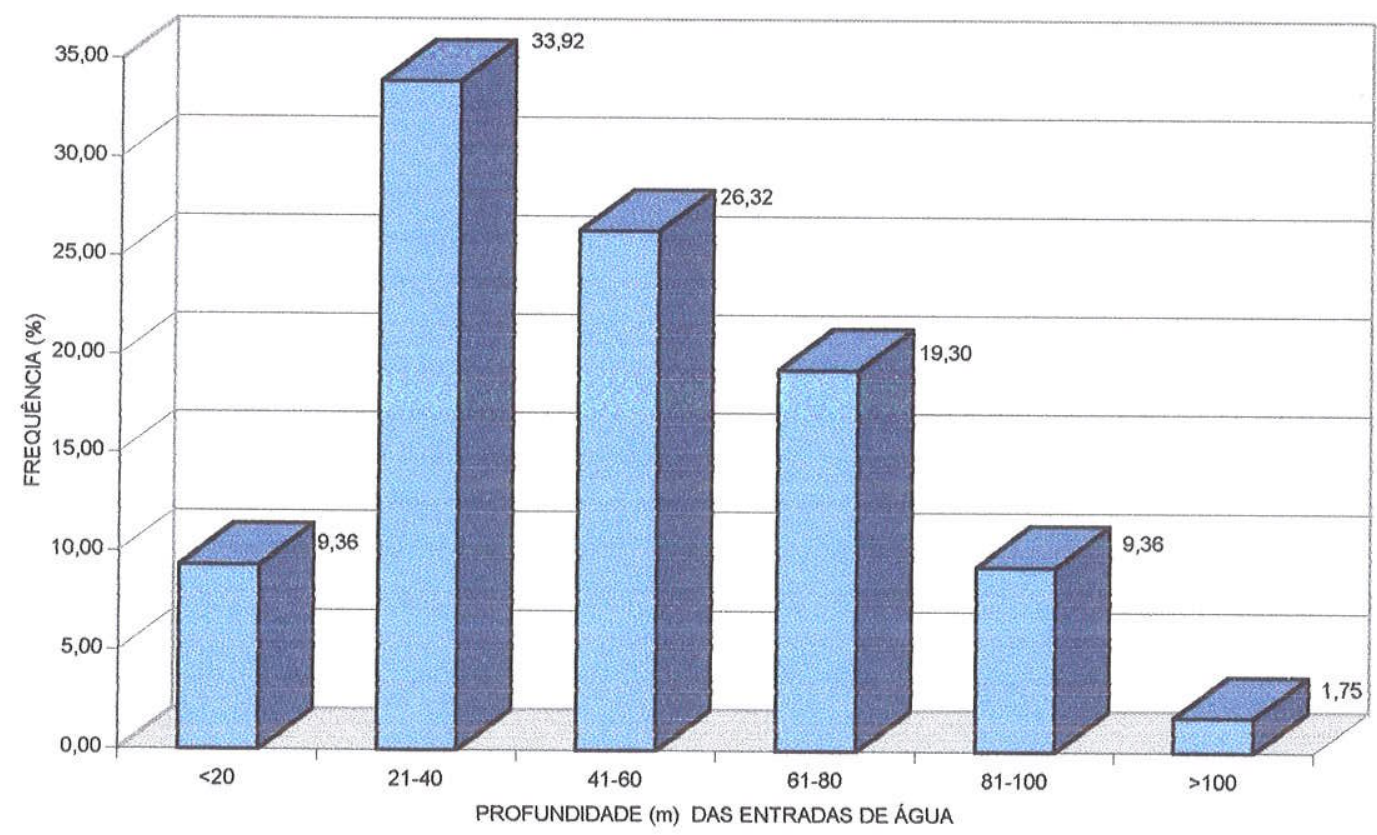

Figura 32: Frequência das profundidades das entradas de água (171 poços)

\section{5 - Análise dos lineamentos}

O termo Lineamento utilizado no transcorrer deste trabalho define qualquer traço linear fotointerpretado, sem distinção entre falhas, fraturas, juntas e diáclases.

Esta definição permite um estudo plano, sem valorizar demais ou desvalorizar qualquer estrutura geológica. O fator mais importante deste estudo será a análise do cruzamento das informações obtidas através da fotointerpretação com outros níveis de informação como produtividade, prospecção e planejamento futuro. 
Para definir as zonas mais promissoras dentro da área de estudo foram analisados as direções e as extensões dos lineamentos. Isto estabelecido iniciou-se o cruzamento das informações dos poços como vazão, número de entradas de água e critério de locação. Embora os dados de capacidade específica de aqüíferos fraturados apresentem pouca consistência foram utilizados apenas como referência para definir os locais mais promissores.

O mapa de lineamentos confeccionado neste trabalho (Anexo II) foi correlacionado ao mapa de drenagem e observou-se que a mesma está parcialmente superimposta aos lineamentos principalmente na área central (Bacia do Cachoeira), Bacia do Rio Cubatão, Rio Pirai e Palmital. Porém, localmente, está subordinada às características estruturais das rochas, características estas que induzem a recarga do aqüífero.

\subsection{1 - Extensão dos lineamentos}

Com referência à extensão dos lineamentos o presente estudo mostrou que $69,5 \%$ dos lineamentos apresentam extensões entre $100 \mathrm{~m}$ e $1000 \mathrm{~m}$ e apenas $1,1 \%$ apresentaram extensões superiores a $2.500 \mathrm{~m}$. A figura 33 mostra esta distribuição:

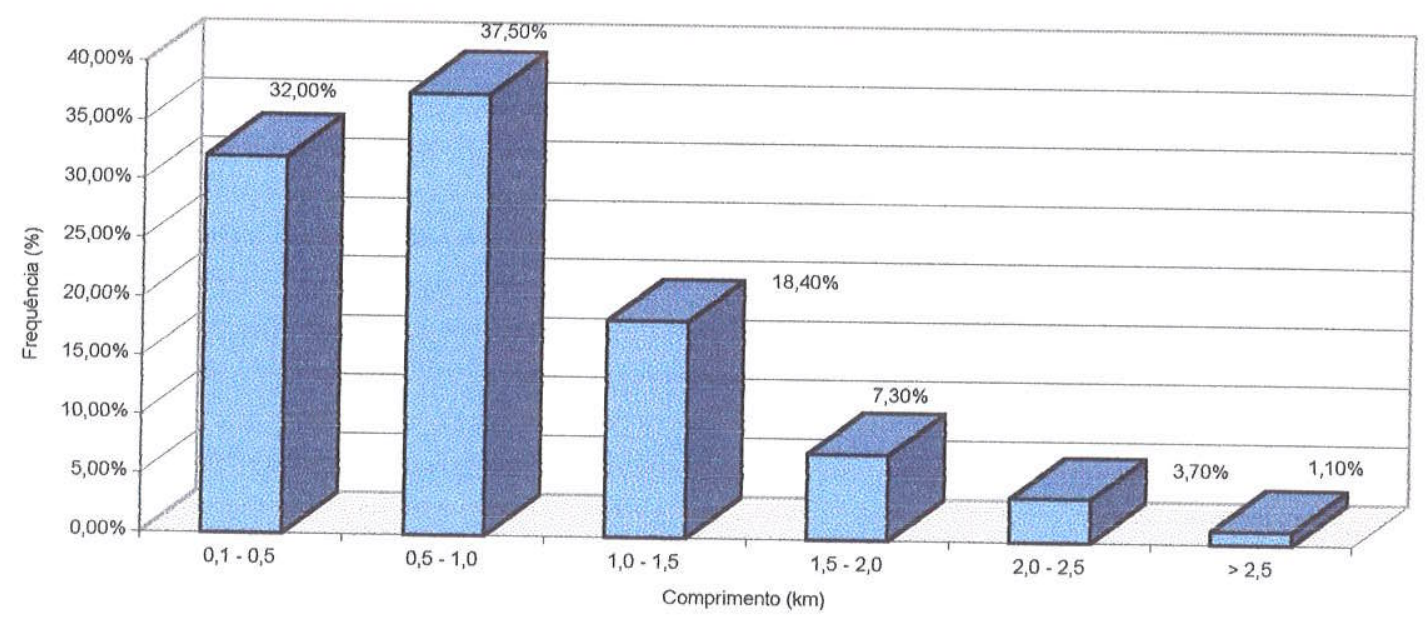

Figura 33: Frequência da extensão dos lineamentos fotointerpretados (n=272)

\subsection{2 - Direção dos lineamentos}

As direções dos lineamentos fotointerpretados revelaram a nível local duas grandes famílias principais: a primeira e mais sobressalente com direção NE e a segunda, praticamente perpendicular a esta, a NW. Porém, há ainda ocorrência de lineamentos NS e EW. 
A figura 34 mostra a frequência das direções dos lineamentos.

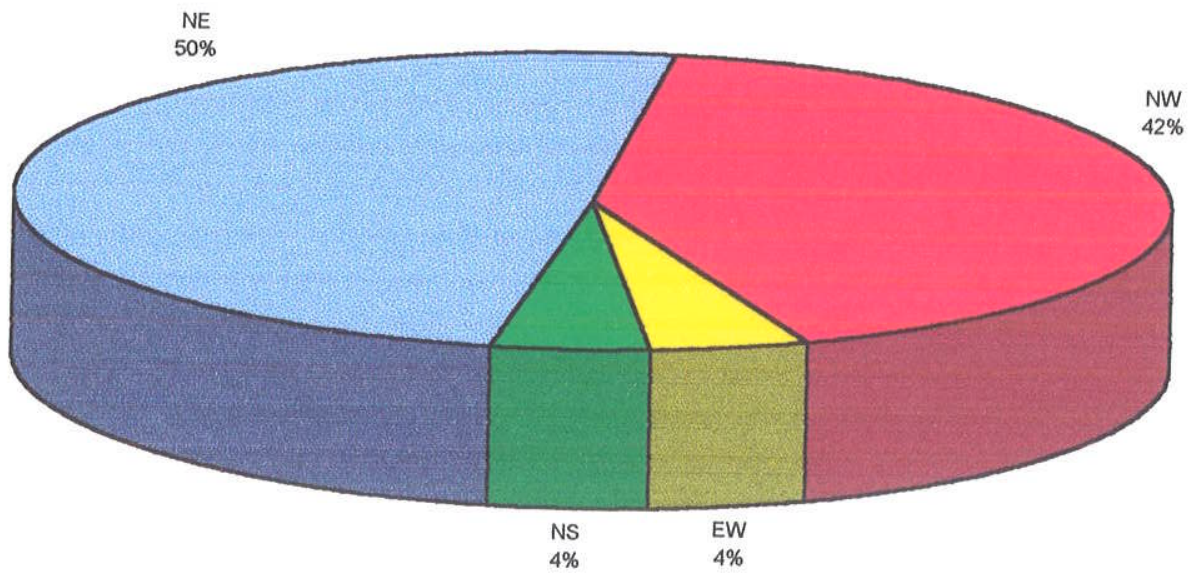

Figura 34: Frequência das direções dos lineamentos fotointerpretadas $(\mathbf{n}=\mathbf{2 0 2})$

O diagrama de rosetas (Figura 35), mostra as duas grandes famílias de lineamentos fotointerpretados.

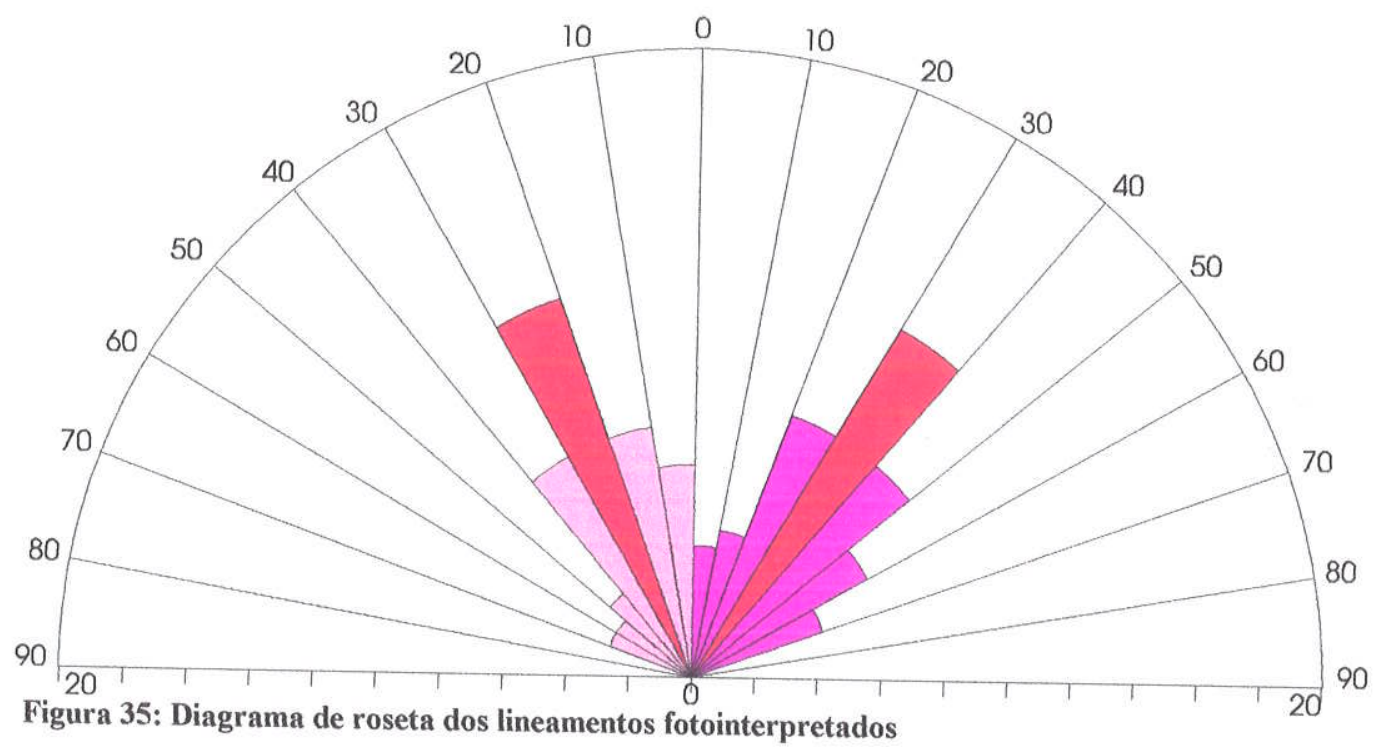

A correlação entre as direções NE e NW, extensão dos lineamentos e as vazões observadas na área de estudo será discutido no ítem 7.5.3. 
Com relação aos lineamentos direcionados a NE, constatou-se que as maiores ocorrências estão entre $30^{\circ}$ e $40^{\circ}(24 \%)$ seguido das variações $20^{\circ}-30^{\circ}$ e $40^{\circ}-50^{\circ}$ com $18 \%$ cada uma. Portanto $60 \%$ dos lineamentos direcionados a NE estão concentrados nesta faixa, conforme mostra a figura 36 .

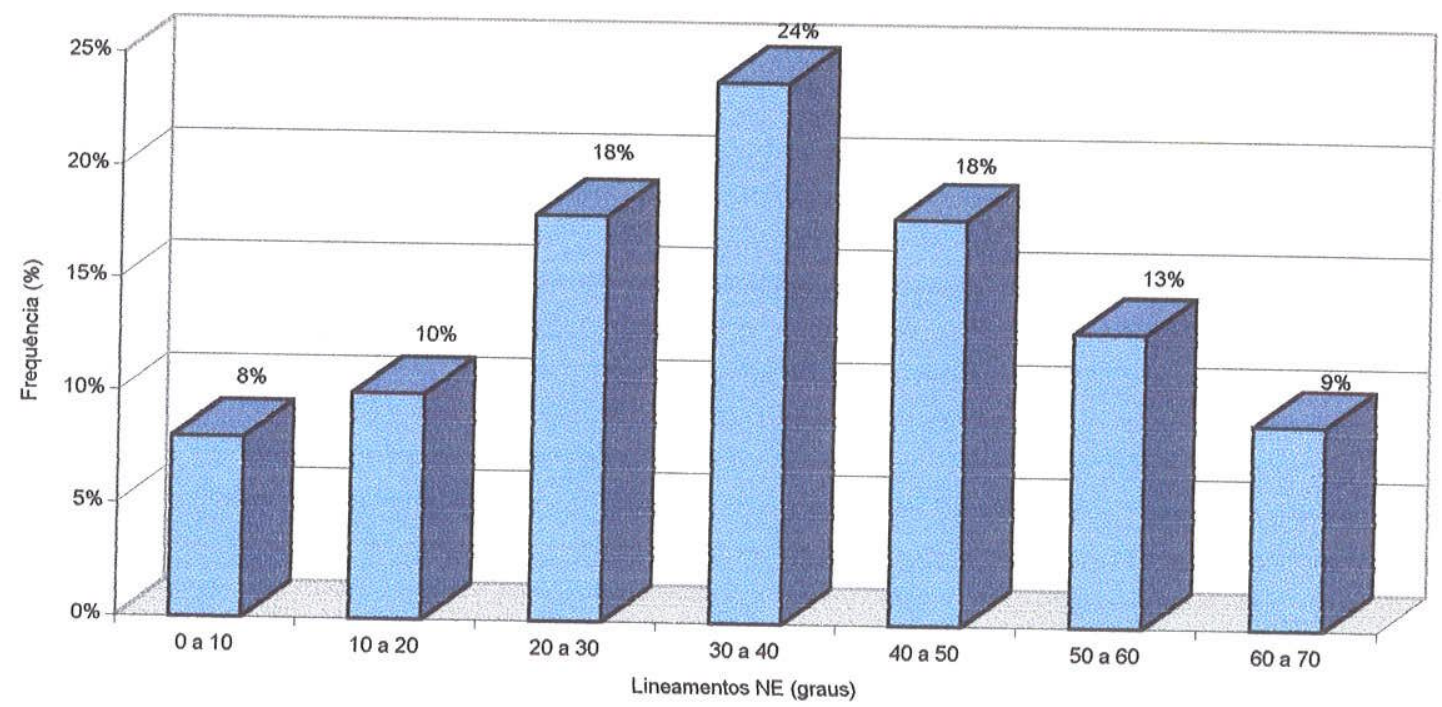

Figura 36: Frequência das direções a NE $(n=100)$

Quanto aos lineamentos direcionados a NW, constatou-se que as maiores frequências estão situadas em torno de $20^{\circ}$ e $30^{\circ}(28,57 \%)$, seguidos das direções N10-20W e N30-40W, com $19,05 \%$ coincidentemente.

A figura 37 mostra a frequência dos lineamentos a NW.

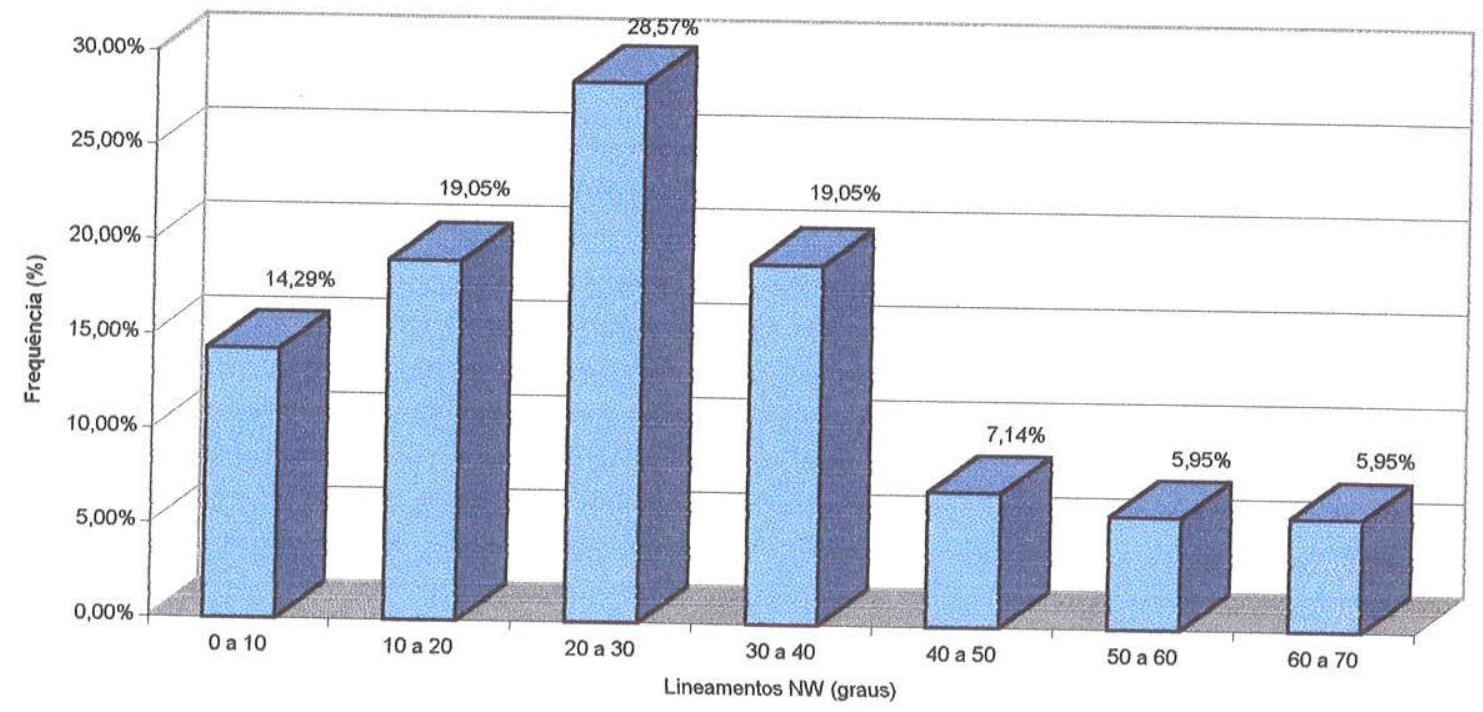

Figura 37: Frequência das direções a NW $(n=84)$ 
7.5.3 - Relação entre lineamentos e produtividade:

Odling (1993) descreve que em algumas circunstâncias especificas os argumentos geológicos, quantitativos e qualitativos possibilitam alto grau de correlação entre a abertura extensão e direção dos lineamentos que compõem o aqüífero. Estas características conferem maiores ou menores produtividades.

Esta pesquisa não teve instrumentação para definir os parâmetros de abertura dos lineamentos, portanto desconhece-se quais os lineamentos são abertos ou fechados. Sabe-se que a produtividade está associada a este fator. Porém foi realizada para os poços em operação uma análise comparativa da produtividade associada à extensão e direção dos lineamentos. $O$ resultado sugere que as estruturas mais produtivas são aquelas direcionadas a NE com extensão média de $1300 \mathrm{~m}$, sendo que as maiores produções estão associadas a locais de interferência de dois ou mais lineamentos, como é o caso dos poços 7, 52, 92 e 106.

Entretanto, esta dedução executada por comparação poderá ser alterada, conforme sejam perfurados novos poços, ou através de pesquisa com este objetivo o que significa dizer que lineamentos em direçбes EW ainda não estão descartados.

A tabela 22 mostra o resultado da análise.

Tabela 22: Relacão entre extensão, direcão e produtividade dos pocos locados sobre lineamentos

\begin{tabular}{|c|c|c|c|}
\hline N. Poco (s) & Extensão & Direção & Produtividade \\
\hline 88 e 33 & $1300 \mathrm{~m}$ & N4IE & $15 \mathrm{~m}^{3} / \mathrm{h}$ \\
\hline $01 \mathrm{e} 06$ & $1500 \mathrm{~m}$ & $\mathrm{~N} 22 \mathrm{E}$ & $7 \mathrm{~m}^{3} / \mathrm{h}$ \\
\hline 15 & $1000 \mathrm{~m}$ & $\mathrm{~N} 38 \mathrm{E}$ & $7.9 \mathrm{~m}^{3} / \mathrm{h}$ \\
\hline 16 & $1400 \mathrm{~m}$ & N60E & $10.28 \mathrm{~m}^{3} / \mathrm{h}$ \\
\hline 92 & $1000 \mathrm{~m}$ & N53E & $15 \mathrm{~m}^{3} / \mathrm{h}$ \\
\hline 93 & $1500 \mathrm{~m}$ & $\mathrm{~N} 38 \mathrm{~W}$ & $6.50 \mathrm{~m}^{3} / \mathrm{h}$ \\
\hline 7 & $2100 \mathrm{~m}$ & No8W & $8.5 \mathrm{~m}^{3} / \mathrm{h}$ \\
\hline $26,28 \mathrm{e} 19$ & $2500 \mathrm{~m}$ & $\mathrm{~N} 25 \mathrm{~W}$ & $12 \mathrm{~m}^{3} / \mathrm{h}$ \\
\hline 105 e 106 & $1000 \mathrm{~m}$ & N63E, N18E e N10E & $15 \mathrm{~m}^{3} / \mathrm{h}$ \\
\hline 61 & 1500 & $\mathrm{~N} 24 \mathrm{E}$ & $15 \mathrm{~m}^{3} / \mathrm{h}$ \\
\hline 52 & $1500 \mathrm{~m} \mathrm{e} 1100 \mathrm{~m}$ & N44E e N06E & $15 \mathrm{~m}^{3} / \mathrm{h}$ \\
\hline 62 & $900 \mathrm{~m}$ & N37E & $1 \mathrm{Im}^{3} / \mathrm{h}$ \\
\hline
\end{tabular}


7.6 - Hidroquímica das águas subterrâneas de Joinville

\subsection{1 - Legislação pertinente}

A legislação Brasileira definiu em âmbito Federal os Parâmetros e as concentrações máximas permitidas, principalmente com respeito à água para consumo humano. A nível Estadual foi publicado no Diário Oficial de Santa Catarina a lei 9748 de 30/11/94 que dispõe sobre a política Estadual de Recursos hídricos.

A nível de Joinville foi sancionada a lei complementar ${ }^{\circ}{ }^{\circ} 29$ de 14 de junho de 1996 que institui o código do Meio Ambiente. Este código prevê o gerenciamento dos recursos hídricos do município, incluindo as águas subterrâneas. Será necessário ainda a regulamentação do Código.

A tabela 23 mostra resumidamente as legislações que regulamentam os parâmetros e os valores máximos permitidos (VMP) para águas de consumo humano e industrial.

\subsection{2 - Interação entre meio físico e composição das águas}

A composição química das águas subterrâneas é resultante da interação água-rocha.

Em climas tropicais, com altíssimos índices de pluviosidade, como em Joinville a ação da água sobre as litologias é extremamente intensa. Este fato confere à água uma concentração de elementos químicos a partir da hidratação e hidrólise dos silicatos.

As litologias envolvidas compreendem principalmente, gnaisses, quartzitos, formações ferriferas entre outras de menor expressão. Os elementos mais abundantes são $\mathrm{Ca}^{++t}, \mathrm{Mg}^{+1+}, \mathrm{Na}^{+1+}$ $\mathrm{e} \mathrm{K}^{++}$. Portanto, as águas subterrâneas apresentam maiores ou menores teores destes elementos conforme a disponibilidade dos íons $\mathrm{HCO}_{3}{ }^{\circ}, \mathrm{Cl}^{-}$e $\mathrm{SO}_{4}{ }^{-}$(Cruz 1985, in Menegasse, L. N 1991).

O estudo hidroquímico desenvolvido neste trabalho apresenta as características FísicoQuímicas das águas subterrâneas de Joinville. 
Dos 113 poços cadastrados para este estudo 30 (trinta) apresentam análises laboratoriais da qualidade da água. Destes, vinte e um puderam ser utilizados uma vez que apresentam suas características físico químicas mais completas e consistentes.

Estas análises foram executadas pelo TECPAR - Instituto de Tecnologia do Paraná, logo após a perfuração dos Poços. A tabela 24 apresenta os resultados:

Tabela 24: Resultado das análises de água dos pocos tubulares profundos.

\begin{tabular}{|c|c|c|c|c|c|c|c|c|c|c|c|c|c|}
\hline Poço & C.E & $\mathrm{pH}$ & $\mathrm{NO}_{3}{ }^{-}$ & $\mathrm{Cl}^{\circ}$ & $\mathrm{SO}_{4}{ }^{\prime \prime}$ & $\mathrm{HCO}_{3}$ & $\mathrm{SiO}_{2}$ & $\mathrm{CO}_{2}$ & $\mathrm{Ca}$ & $\mathrm{Mg}$ & $K$ & $\mathrm{Na}$ & Dureza \\
\hline 1 & 106,7 & 6,82 & nd & nd & nd & nd & 47,1 & nd & 8,8 & 2,8 & 2,9 & nd & $n p$ \\
\hline 3 & 148,5 & 6,95 & nd & 10,6 & 3,1 & 77,6 & 58,6 & 6,6 & 13,5 & 7,2 & 2,2 & 7,2 & 68 \\
\hline 4 & 187,7 & 7,41 & nd & 7,1 & 10,1 & 115,9 & 43,6 & 4,4 & 18,4 & 9,2 & 3 & 12,8 & 76 \\
\hline 5 & np & 7,6 & 1 & 218 & 14 & $n p$ & $n p$ & $n p$ & $n p$ & $n p$ & $n p$ & np & 149 \\
\hline 6 & 1111 & 7.9 & 2,9 & 269,9 & 133,8 & 164,7 & 33 & 4,4 & 26,8 & 8,7 & 2,7 & 253,5 & 98 \\
\hline 10 & 272 & 7 & 1,7 & 14,6 & 11,8 & 136,9 & 52,9 & 6,6 & 25,2 & 11,2 & 2,4 & 15,8 & 104 \\
\hline 11 & 101,2 & 6,1 & 9,9 & 11,3 & $n d$ & 33,3 & 10,7 & 26,4 & 2,5 & 5 & 0,5 & 10,9 & 26,5 \\
\hline 14 & 200 & 8 & nd & 49,7 & $n p$ & $n p$ & $n p$ & $n p$ & 1,6 & 9,6 & np & np & 44 \\
\hline 15 & 325 & 6,2 & nd & 16 & 6 & 193,1 & 42 & 8,8 & 20,3 & 7,4 & 3 & 46,9 & 81 \\
\hline 16 & $\mathrm{np}$ & 6,98 & nd & 7,8 & 4,7 & 79.3 & 32,8 & 4,4 & 15,1 & 3,4 & 0,9 & 12,9 & 54 \\
\hline 17 & 106 & 7,06 & nd & 5,3 & 1,3 & 61,7 & 47,1 & 8,8 & 9,1 & 3,8 & 2,3 & 8,4 & 39 \\
\hline 21 & np & 7,2 & $n p$ & 34 & np & $n p$ & 28,75 & $\mathrm{np}$ & np & $\mathrm{np}$ & $n p$ & $n p$ & 115 \\
\hline 32 & $n p$ & 7,3 & 0,93 & 5 & 3 & 80 & 25 & 7,84 & 12,25 & 5,25 & 2,28 & 12,23 & 58 \\
\hline 42 & 112,6 & 6,8 & 0,9 & 3,6 & nd & 66,6 & 43 & 6,6 & 8,2 & 4,5 & 2,1 & 8,6 & 38,8 \\
\hline 44 & 92,5 & 6,6 & 0,6 & 5,3 & nd & 59,9 & 54,2 & 11 & 7,4 & 4,5 & $\{, 8$ & 8,1 & 32,6 \\
\hline 49 & 197,7 & 6,9 & 1,7 & 5,7 & 2,4 & 122 & 56,8 & 8,8 & 21,6 & 6,3 & 1,5 & 12 & 80 \\
\hline 57 & 85,3 & 6,7 & $n p$ & 11 & $n p$ & $n p$ & $n p$ & 25 & 5,68 & 3,86 & $n p$ & np & 30,3 \\
\hline 60 & $n p$ & 7,35 & nd & 8,1 & 2,4 & 158,6 & 51,4 & 6,6 & 9,6 & 3,8 & 10 & 42,1 & 40 \\
\hline 64 & $n p$ & 7,3 & nd & 17,7 & 8,6 & 158,6 & 47,4 & 6,6 & 20,8 & 11,2 & 3,4 & 26,8 & 88 \\
\hline 66 & 171,3 & 7,57 & nd & 12,4 & 4,1 & 103,7 & 30,6 & 4,4 & 21,6 & 7,3 & 1,1 & 9,9 & 84 \\
\hline 100 & 169,4 & 7,4 & nd & 10,7 & nd & 98,2 & 20,3 & 4,4 & 19,3 & 4,6 & 1,2 & 12,4 & 64 \\
\hline
\end{tabular}

np-não pesquisado / nd-não detectado - As unidades dos parâmetros acima estão descritas no texto.

\subsection{3 - Propriedades físicas}

Foram avaliadas as características de Turbidez, cor, sabor, odor, temperatura e condutividade elétrica. 
As águas subterrâneas de Joinville são águas cristalinas sem cor aparente, com temperaturas oscilando em 19 e 21 graus, turbidez média variando entre 2,5 a 3,0 unidades nefelométricas de turbidez (NTU), e não apresentam odor ou sabor característicos, portanto dentro dos padrões da legislação brasileira, salvo os poços em que a concentração de cloretos torna as águas salobras.

Com relação à condutividade elétrica (CE), foi elaborada uma análise que envolveu 15 poços. Os resultados mostraram que em $80 \%$ das amostras os valores de CE variam de 85 a 200 micromho/cm. Porém em $6.6 \%$ das amostras a CE foi superior a $1000 \mathrm{micromho} / \mathrm{cm}$.

A partir da análise do comportamento da Condutividade Elétrica e dos cloretos foi possível verificar a forte correlação que existe entre eles. A figura 38 expressa esta forte correlação.

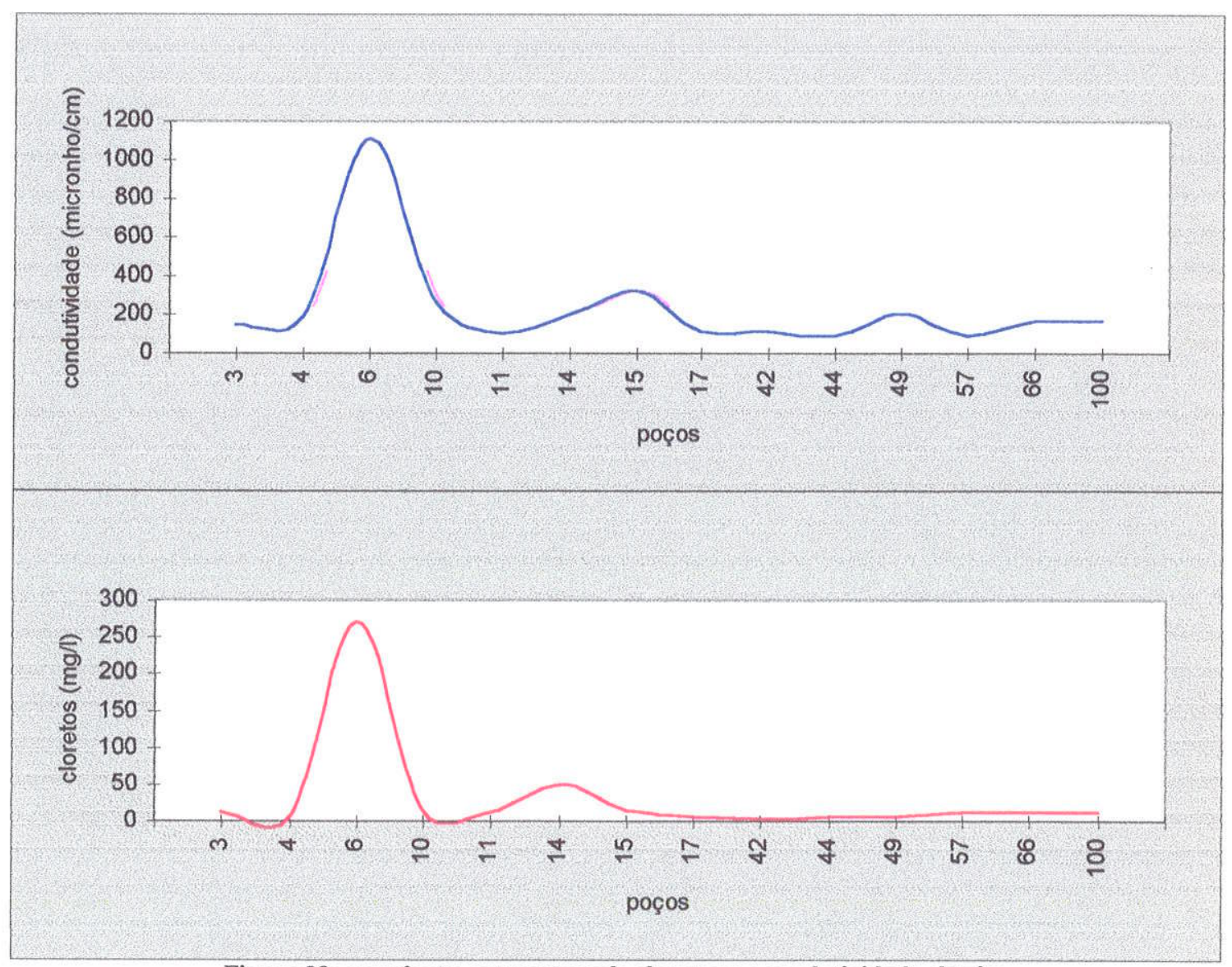

Figura 38: correlação entre o teor de cloretos e a condutividade elétrica 


\section{6 .4 - Propriedades químicas}

Para a análise das propriedades químicas das águas subterrâneas de Joinville, foram separadas as características orgânicas das inorgânicas. Este fator permitiu a distinção das propriedades herdadas das rochas daquelas decorrentes das ações antrópicas ou dos regimes naturais das marés.

\subsubsection{1 - Componentes orgânicos}

$\mathrm{Na}$ composição orgânica das águas subterrâneas existem componentes gerados basicamente por duas fontes distintas: As naturais e as decorrentes da ação antrópica. A tabela 25 resume estes componentes.

Tabela 25: Componentes orgânicos naturais e decorrentes da ação antrópica

\begin{tabular}{|c|c|}
\hline COMPONENTES ORGANICOS NATURAIS & $\begin{array}{c}\text { COMPONENTES DECORRENTES DA ACAOO } \\
\text { ANTROPICA }\end{array}$ \\
\hline $\begin{array}{l}\text { Húmus } \\
\text { Interaçôes de Microorganismos } \\
\text { Compostos naturais efluchtes da degradação da } \\
\text { matéria Orgânica. }\end{array}$ & $\begin{array}{l}\text { - Lancamento de aguas residuárias sanitárias ou } \\
\text { industriais, } \\
\text { - Escoamento superficial urbano ou rural, } \\
\text { Escoamento subsuperficial (galerias, sistenas de } \\
\text { esgotos), } \\
\text { Compostos orgânicos voláteis como o Benzeno, } \\
\text { tetracloreto de carbono e outros, } \\
\text { - Agrotóxicos em geral, e } \\
\text { Compostos orgânicos sintéticos como tolueno, xileno e } \\
\text { outros. }\end{array}$ \\
\hline
\end{tabular}

Para quantificar os componentes orgânicos naturais, utilizou-se a análise laboratorial do oxigenio consumido em meio ácido. Deste procedimento resultou a composição da água.

As concentrações máximas de componentes orgânicos naturais estão em torno de 3,0 $\mathrm{mg} / \mathrm{L}(6,6 \%)$. Mas as ocorrências predominantes apresentam valores entre 0,1 a $1,0 \mathrm{mg} / \mathrm{L}$ e correspondem a $66 \%$ das frequências. A figura 39 mostra esta distribuição. 


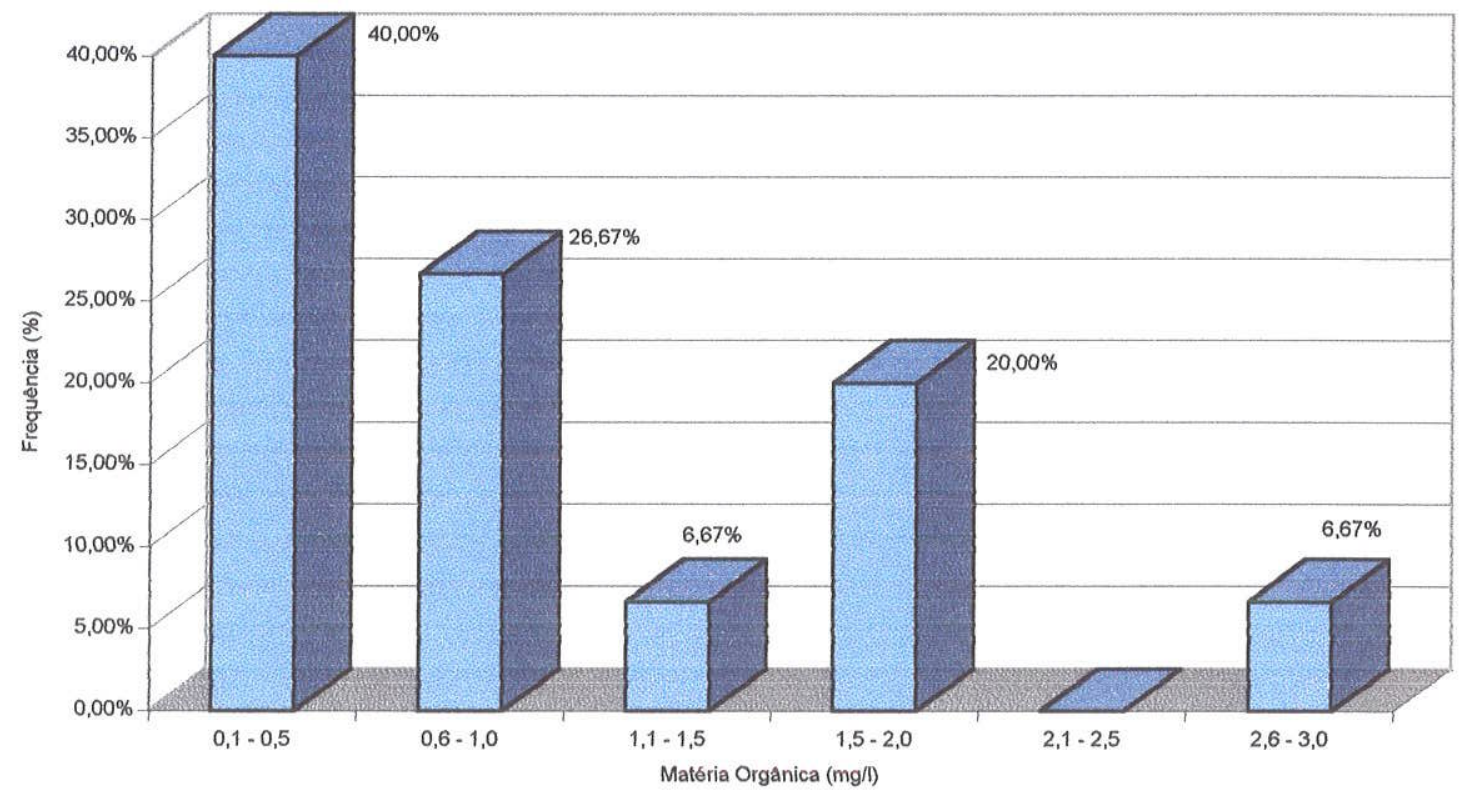

Figura 39: Frequência dos valores de compostos orgânicos (15 poços)

No que diz respeito aos componentes decorrentes da ação antrópica, uma das pesquisas que as quantificam é a do halogenado orgânico total (HOT), que indica a presença de compostos orgânicos halogenados.

Em Joinville, as atividades industriais e agrícolas geram efluentes com grande concentração de compostos orgânicos e sintéticos na zona industrial, domínios da Bacia do Rio Cachoeira e compostos químicos efluentes de agrotóxicos na zona rural do município nas Bacias do Rio Cubatão, Pirai entre outros.

Porém um dos maiores problemas para quantificar estes compostos é o custo e a tipologia de análises necessárias. Geralmente, estas pesquisas não são realizadas para águas subterrâneas. Por isso nem a medida do halogenado orgânico total, nem a quantificação e avaliação da concentração de substâncias orgânicas decorrentes da ação antrópica fazem parte dos objetivos desta dissertação. Muito embora, se tenha conhecimento que nas áreas de recarga do aqüífero, haja interferência e despejo destes compostos.

\subsubsection{2 - Componentes inorgânicos}

Foram avaliados os resultados obtidos das análises laboratoriais, executadas logo após a perfuração dos poços. Os parâmetros analisados foram: pH, sólidos totais dissolvidos (STD), 
sulfatos, cloretos, nitratos, ferro, dureza, sódio, potássio, magnésio, cálcio, gás carbônico livre, sílica e bicarbonatos.

\section{- Alcalinidade, Acidez e pH.}

A alcalinidade pode ser entendida como a capacidade da água em neutralizar ácidos e a acidez como de neutralizar bases. Por sua vez o pH (potencial hidrogeônico) avalia o ponto de equilíbrio entre estas forças e, geralmente, está associado ao valor numérico resultante do sistema $\mathrm{H}_{2} \mathrm{CO}_{3}$ e $\mathrm{HCO}_{3}-$.

A acidez depende do $\mathrm{pH}$, pois é função do $\mathrm{CO}_{2}$ presente nos valores inferiores a $8,3 \mathrm{e}$ superiores a 4,4 .

As análises Físico-Químicas da água dos poços cadastrados em Joinville mostram pH variando entre 6 e 8,5. Isso mostra que a alcalinidade é oriunda, principalmente de bicarbonatos e secundariamente de carbonatos (Di Bernardo, 1993).

As análises de água mostraram que praticamente $43 \%$ das ocorrências apresentam pH oscilando entre 6,6 a 7,0 e $29 \%$ entre 7,1 a 7,5. O pH entre 6,0 e 6,5 apresentou uma frequência de $9,5 \%$ e acima de 7,6 ao redor de $19 \%$.

A figura 40 mostra esta distribuição.

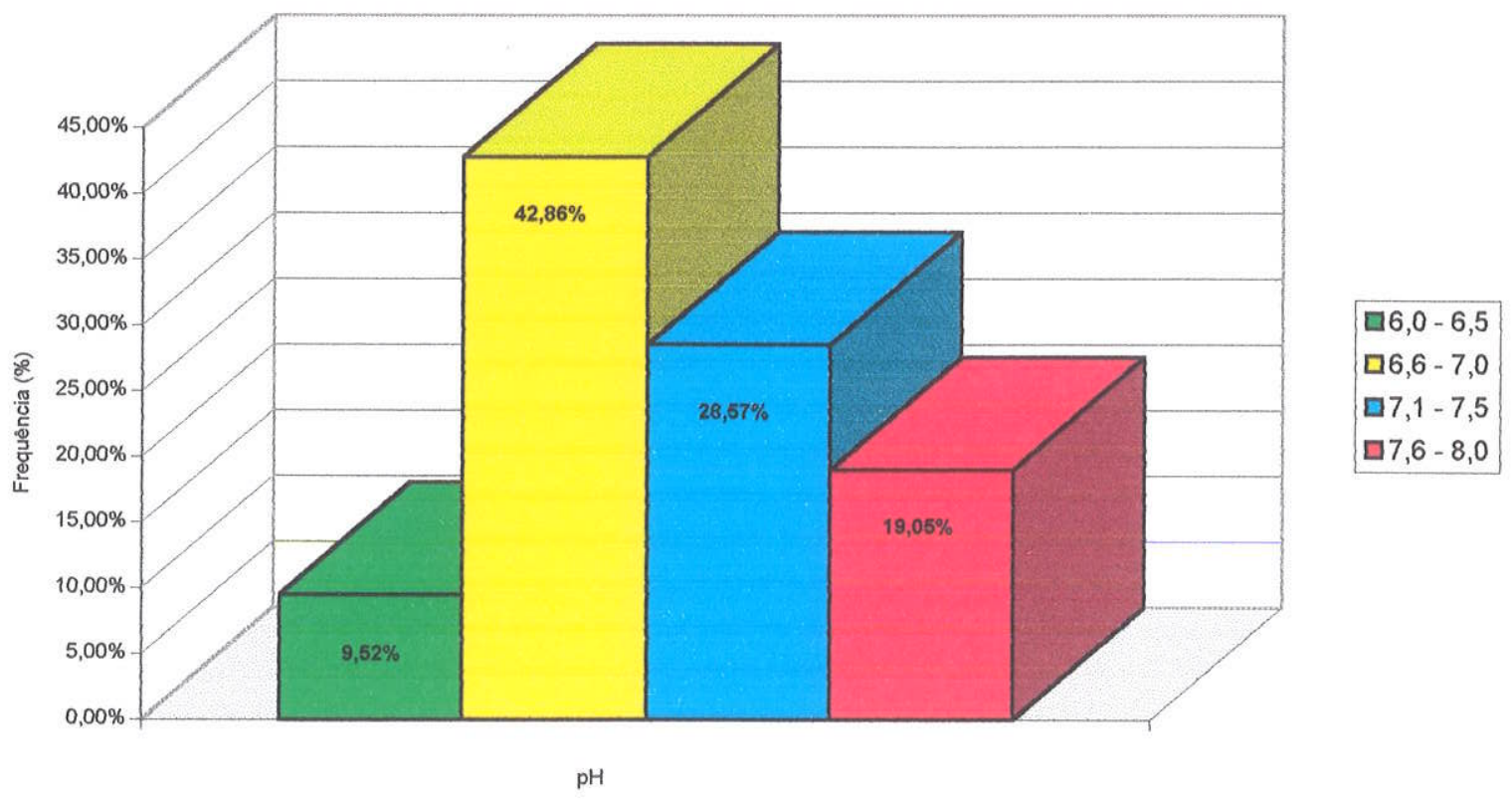

Figura 40: Frequência dos valores de pH (21 poços) 


\section{- Sólidos totais dissolvidos}

Os valores máximos de STD foram de 200 a $280 \mathrm{mg} / \mathrm{L}$ e apresentam forte correlação com a presença de cloretos. Os valores médios não ultrapassaram $25 \mathrm{mg} / \mathrm{L}$.

\section{- Sulfatos}

A concentração de sulfatos, legalmente permitida, está em $250 \mathrm{mg} / \mathrm{L}$. Na pesquisa, os valores máximos atingiram valores superiores a $100 \mathrm{mg} / \mathrm{L}$, bem abaixo do máximo permitido e correspondem a apenas $5,5 \%$ das amostras pesquisadas. A maior concentração (66\%) está em torno de 10 a $20 \mathrm{mg} / \mathrm{L}$ enquanto que em $27 \%$ não foi detectada a presença de sulfatos.

\section{- Cloretos:}

Também caracterizam os sólidos totais dissolvidos. São indicadores de poluição (aterros sanitários, efluentes domésticos). Porém em cidades próximas ao litoral, como é o caso de Joinville, sob influência das marés, há transferência deste composto para as camadas inferiores do solo podendo atingir aqüíferos em exploração (poço 06).

Legalmente, os valores máximos permitidos para a concentração de cloretos é $250 \mathrm{mg} / \mathrm{L}$. A maior ocorrência nas análises é a concentração de 1 a $30 \mathrm{mg} / \mathrm{L}$ que somam $76 \% .9 .5 \%$ correspondem a concentrações entre 30 e $60 \mathrm{mg} / \mathrm{L}, 4,7 \%$ entre 150 e $250 \mathrm{mg} / \mathrm{L}$ e $4,7 \%$ apresentam valores superiores a $250 \mathrm{mg} / \mathrm{L}$ e correspondem fisicamente às regiões do aqüifero que sofrem efeitos de maré ao longo do Rio Cachoeira (Anexo II). Ainda nesta pesquisa, em $4,7 \%$ das amostras não foi detectada a presença de cloretos.

\section{- Nitratos:}

A presença de compostos de Nitrogênio de origem orgânica, pode ser indicador de contaminação recente (Nitrogênio Orgânico Amoniacal). A pesquisa laboratorial para nitratos mostrou que em aproximadamente $58 \%$ das amostras não foi detectada a presença de nitratos. As maiores concentrações de nitratos estão entre 0,1 a $1 \mathrm{mg} / \mathrm{L}(21 \%)$ e 1,1 a $2 \mathrm{mg} / \mathrm{L}(10,5 \%)$. As demais ocorrências correspondem a concentrações de 2,1 a $3 \mathrm{mg} / \mathrm{L}$ (5\%) e valores superiores a 9 $\mathrm{mg} / \mathrm{L}(5 \%)$. O valor máximo constatado foi de $9,9 \mathrm{mg} / \mathrm{L}$

O valor máximo permitido para nitratos é $10 \mathrm{mg} / \mathrm{L}$ e a ingestão contínua de água com excesso de Nitratos pode provocar a metahemoglobinemia. 


\section{- Ferro:}

A concentração máxima de ferro total legalmente permitida para consumo humano é 0,3 $\mathrm{mg} / \mathrm{L}$

Um dos usos das águas captadas no subsolo é a refrigeração dos maquinários ou ainda o aquecimento destas águas para uso em piscinas ou redes de distribuição de água quente em hotéis e motéis. Os sistemas de aquecimento utilizam-se de serpentinas onde o ferro, geralmente associado a bicarbonatos e cloretos, precipita-se e danifica equipamentos e redes de distribuição.

$\mathrm{Na}$ pesquisa foi constatado que aproximadamente $68 \%$ dos poços apresentam concentrações de ferro total menores que $0,3 \mathrm{mg} / \mathrm{L}$ (destes $12,5 \%$ não apresentou $\mathrm{Fe}$ ). Porém foi também verificado que as ocorrências de concentração superiores a 0,3 perfazem $31 \%$ das amostras analisadas e estas também interferem na qualidade das águas utilizadas em indústrias e redes hoteleiras.

Em poços que apresentaram problemas relacionados ao excesso de ferro, a mudança de coloração da água bombeada pode indicar a presença de bactérias de ferro, porém na maioria dos casos são de difícil detecção e requerem a execução de análises bacteriológicas especiais.

A figura 41 mostra a distribuição dos valores de ferro total.

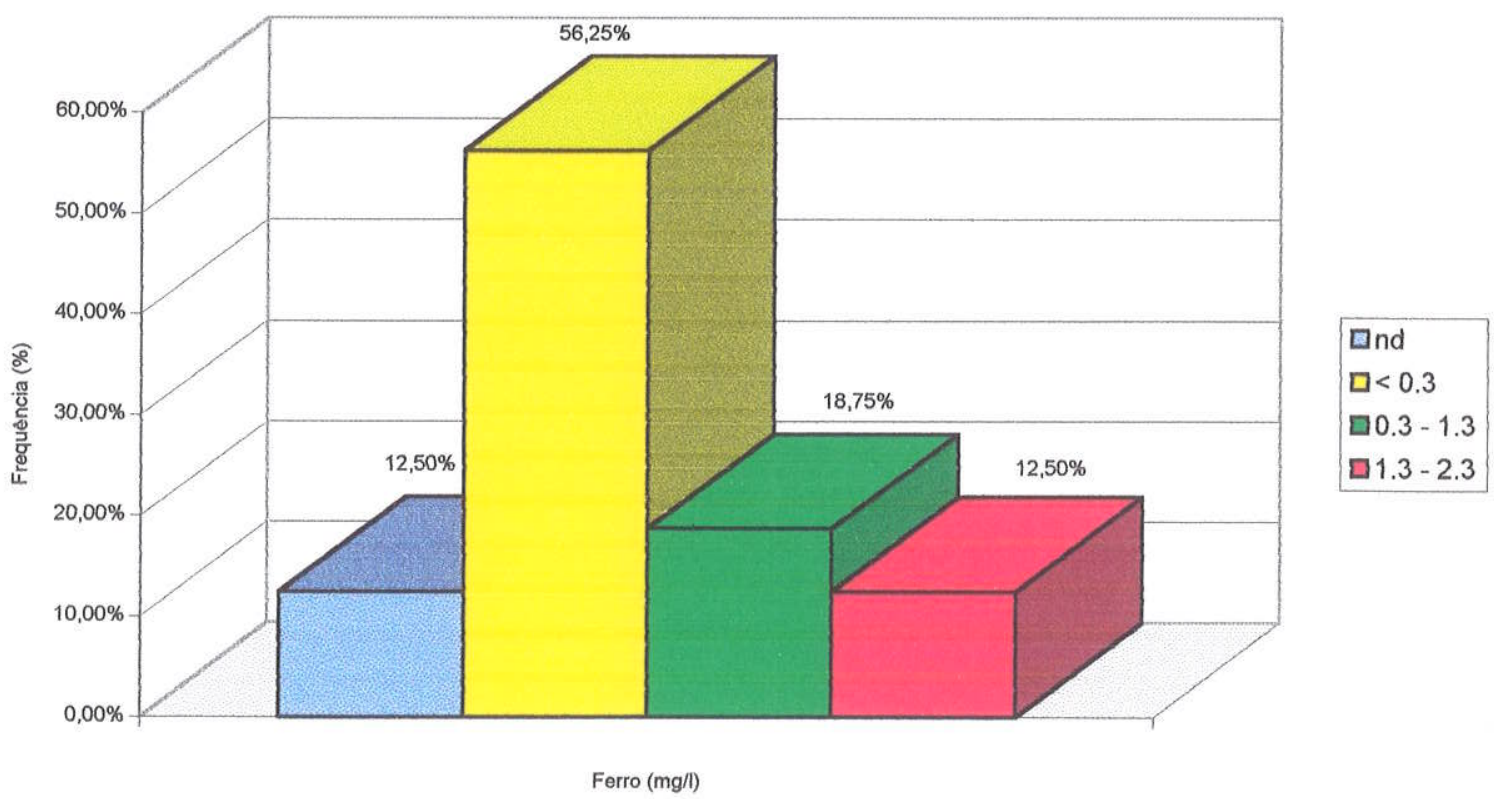

Figura 41: Frequência dos valores de ferro total nas análises de água (16 poços) 


\section{- Dureza:}

Geralmente é definida como a soma de cátions polivalentes presentes na água. Está expressa em termos de quantidade de $\mathrm{CaCO}_{2}$. Geralmente conhecida pela propriedade de precipitar os sabões evitando a formação de espumas.

A análise das amostras mostrou, conforme classificação de dureza de Di Bernardo (1990), que 35\% das águas subterrâneas são Brandas (<50 mg/L), e 65 \% são Moderadas (50 a $150 \mathrm{mg} / \mathrm{L})$.

O resultado da pesquisa está inserido na figura 42:

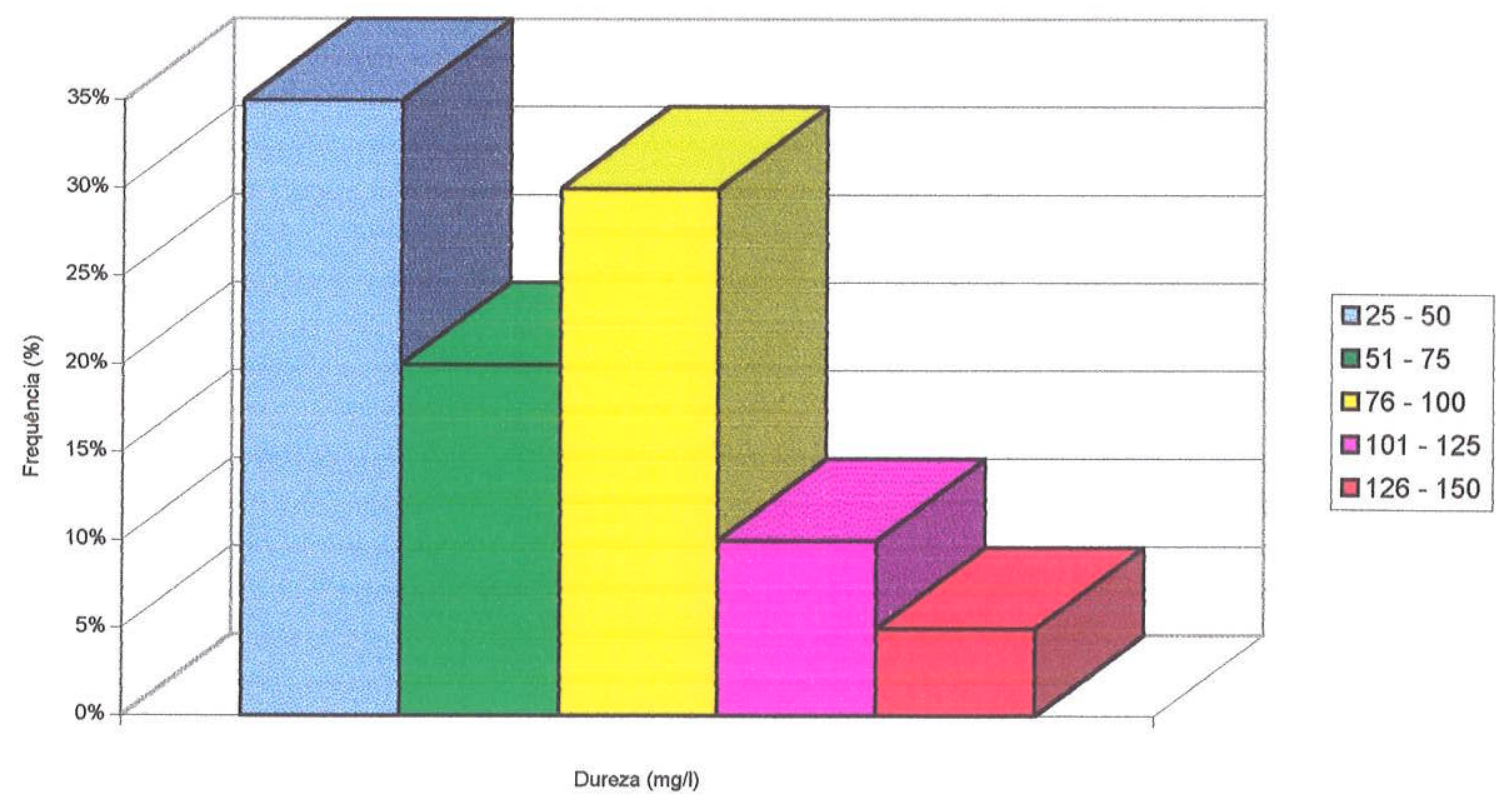

Figura 42: Frequência dos valores de dureza (20 poços)

\section{- Metais Pesados:}

O poço cadastrado sob o n. 09 demonstra as características químicas dos elementos inorgânicos que afetam a saúde. Comparativamente a este poço foi inserida a coluna dos valores máximos permitidos pela Portaria n. 36/GM de 1990. Conforme tabela 26, o poço apresenta-se dentro dos parâmetros legais, porém o monitoramento dos elementos $\mathrm{Cd}, \mathrm{Pb}$ e $\mathrm{Hg}$ deverá ser frequente. 
Tabela 26 - Características químicas dos componentes inorgânicos do poço n. 09 (mg/L)

\begin{tabular}{|c|c|c|}
\hline Elementos & POCO 09 & $\begin{array}{c}\text { V.M.P conforme Portaria } \\
\text { 36/GM 1990 }\end{array}$ \\
\hline Fuoreto & 0,3 & $*$ \\
\hline Cianeto & $<0,03$ & 0,1 \\
\hline As & $<0,05$ & 0,05 \\
\hline Cs & $<0 n 1$ & $n n 1$ \\
\hline
\end{tabular}

\begin{tabular}{|c|c|c|}
\hline$x y$ & 0,2 & 0,0 \\
\hline $\mathrm{Ba}$ & $<0,4$ & 1,0 \\
\hline $\mathrm{Cr}$ & $<0,02$ & 0,05 \\
\hline $\mathrm{Hg}$ & $<0,02$ & 0,001 \\
\hline
\end{tabular}

* Valores recomendados para a concentração do íon Fuoreto $(\mathrm{F})$ conforme valor médio das temperaturas máximas diárias.

\subsection{5 - Concentração química}

A análise da concentração química foi elaborada para a caracterização do nível de mineralização das águas subterrâneas de Joinville. A partir deste estudo confeccionoumse o diagrama de Piper e o enquadramento das águas conforme decreto 7841 de 08/08/1945.

\section{- Sódio}

Mais de $60 \%$ das amostras apresentam concentrações de $\mathrm{Na}$ em torno de 5 a $15 \mathrm{mg} / \mathrm{L}$ Os valores máximos observados giram em torno de 35 a $50 \mathrm{~g} / \mathrm{L}$ e representam em torno de $11 \%$ das amostras. Os Valores que ultrapassam os $250 \mathrm{mg} / \mathrm{L}$ ocorrem em cerca de $6 \%$ das amostras. A principal fonte mineral de sódio nas águas subterrâneas do município são os Feldspatos alcalinos presentes nas rochas.

\section{- Potássio}

A ocorrência do Potássio está intimamente ligada à mineralogia básica das litologias que ocorrem no município, principalmente a muscovita $\mathrm{K} \mathrm{Al}_{2}(\mathrm{OH}, \mathrm{F})\left(\mathrm{Al} \mathrm{Si}_{3} \mathrm{O}_{10}\right)$. Este estudo apontou que $53 \%$ da concentração de $\mathrm{K}$ está em torno de 2 a $3 \mathrm{mg} / \mathrm{L}$ enquanto que apenas $6 \%$ apresentam concentrações superiores a $10 \mathrm{mg} / \mathrm{L}$.

\section{- Magnésio}

A principal fonte mineral de magnésio $(\mathrm{Mg})$ provém da disseminação da biotita $\mathrm{K}(\mathrm{Mg}, \mathrm{Fe})_{3}(\mathrm{OH}, \mathrm{F})_{2}(\mathrm{Al}, \mathrm{Fe}) \mathrm{Si}_{3} \mathrm{O}_{10}$ nas rochas. As concentrações de $\mathrm{Mg}$ foram divididas em três niveis:

- maiores : concentrações em torno de 2 a $6 \mathrm{mg} / \mathrm{L}(53 \%)$,

- intermediárias: concentrações em torno de 6 a $10 \mathrm{mg} / \mathrm{L}(37 \%) \mathrm{e}$

- menores concentrações entre 10 e $12 \mathrm{mg} / \mathrm{L}(10 \%)$. 


\section{- Cálcio}

$31 \%$ das amostras de água apresentam concentrações de Ca oscilando entre 5 a $10 \mathrm{mg} / \mathrm{L}$, $21 \%$ entre 20 e $25 \mathrm{mg} / \mathrm{L}$ e $16 \%$ entre 15 e $20 \mathrm{mg} / \mathrm{L}$. As maiores concentrações acusaram variações entre 25 e $30 \mathrm{mg} / \mathrm{L}$ e representam $10 \%$ das amostras pesquisadas. A principal fonte mineral de Cálcio provém de plagioclásios e Feldspatos alcalinos presentes nos gnaisses.

\section{- Gás Carbônico Livre.}

A pesquisa de $\mathrm{CO}_{2}$ demonstrou que $61 \%$ das amostras coletadas apresentam concentrações que variam entre 4 a $8 \mathrm{mg} / \mathrm{L}$. Os valores mais elevados de $\mathrm{CO}_{2}$ encontrados nas análises de água estão em torno de 25 a $30 \mathrm{mg} / \mathrm{L}$ e representam $11 \%$ das amostras pesquisadas. Outro fator importante é que em $5 \%$ das amostras não foi detectado o $\mathrm{CO}_{2}$.

\section{- Ślica}

Os valores de concentração de Sílica nas análises laboratoriais apresentaram valores entre 10 e $60 \mathrm{mg} / \mathrm{L}$. As concentrações que mais ocorrem estão entre 40 e $60 \mathrm{mg} / \mathrm{L}$ e perfazem mais de $60 \%$ das ocorrências. As concentrações entre 20 e $40 \mathrm{mg} / \mathrm{L}$ correspondem a $32 \%$ enquanto que as concentrações entre 10 e $20 \mathrm{mg} / \mathrm{L}$ respondem por $5,5 \%$. A fonte mineral mais abundante de $\mathrm{SiO}_{2}$ provém do quartzo presente nos quartzitos, gnaisses, e outras rochas.

\section{- Bicarbonatos}

A Pesquisa para Bicarbonatos demonstrou que a principal concentração nas águas subterrâneas de Joinville está em torno de 30 a $80 \mathrm{mg} / \mathrm{L}$ (41\%), as concentrações entre 80 e 180 $\mathrm{mg} / \mathrm{L}$ correspondem a $27 \%$ das ocorrências enquanto que as superiores a $180 \mathrm{mg} / \mathrm{L}$ correspondem a $5 \%$. As pesquisas demostraram ainda que em $5 \%$ das amostras não foram detectados bicarbonatos.

A partir das concentrações dos elementos acima descritos foi elaborado o diagrama de Piper, que mostra que as águas, localmente, tem composição carbonatada a bicarbonatada. 
A figura 43 mostra a distribuição das amostras no diagrama.

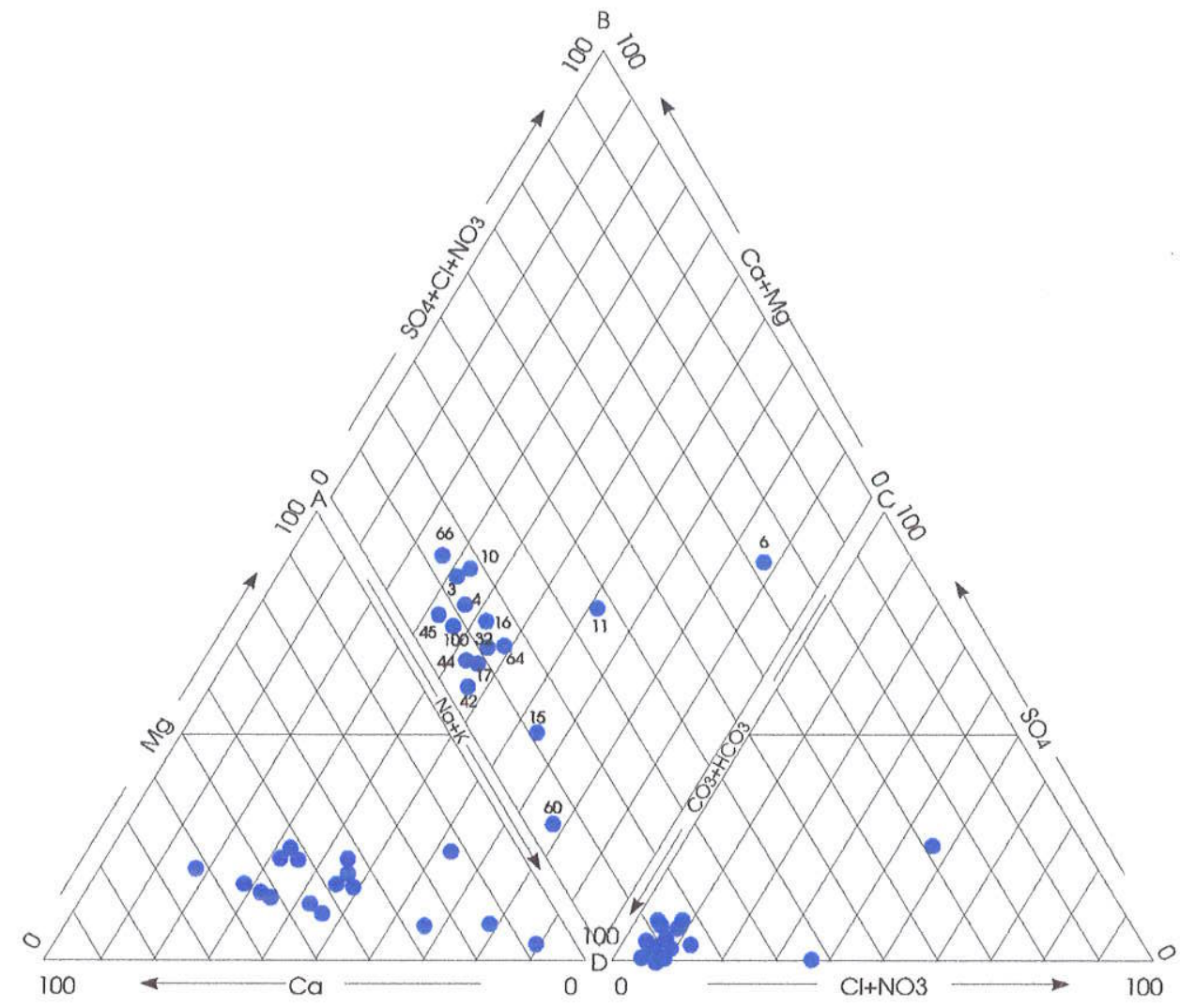

Figura 43: Diagrama de Piper das águas dos poços tubulares.

Uma segunda análise da concentração dos elementos químicos, com base no decreto 7841 de 08 de agosto de 1945, mostra que as águas subterrâneas de Joinville (algumas análises) podem ser enquadradas como águas minerais mistas e águas alcalinas bicarbonatadas, ambas de fontes frias.

Estas análises retratam que as águas subterrâneas de Joinville apresentam:

- Pouco tempo de permanência no Aqüífero Fraturado, e

- Moderada a Baixa mineralização,

Isto pode ser atribuído aos seguintes fatores: aqüífero fraturado raso $(100 \mathrm{~m})$, alta taxa de pluviosidade que provê entrada de água meteórica no sistema, alto grau de alteração das rochas. 


\subsection{6 - Características biológicas:}

A água é o fator mais importante na transmissão de doenças como cólera, amebíase, giardíase, esquistossomose, febre tifóide, febre paratifóide, e desinterias provocadas por patogênicos de veiculação hídrica.

Os coliformes são indicadores de presença recente de fezes e contaminação de origens orgânicas. Quanto maior o número de coliformes maior será a probabilidade de presença de salmonelas, de vírus, amebas, vibrião colérico e outros (DI BERNARDO, 1993).

As análise bacteriológicas das águas subterrâneas de Joinville não apresentaram problemas de coliformes fecais ou coliformes totais. Apenas o poço n. ${ }^{\circ} 4$ mostrou em uma das análises o $\mathrm{n}^{\circ}$ de coliformes fecais superior a $1 / 100 \mathrm{~mL}$ e coliformes totais $4 / 100 \mathrm{~mL}$, o que não se repetiu nas amostras posteriores coletadas no mesmo poço.

Porém paralelamente a este estudo, vem sendo desenvolvido pela Universidade da Região de Joinville - UNIVILLE um monitoramento da qualidade da água de poços rasos utilizados pela população. A grande maioria destes poços encontra-se na área de recarga do aqüifero e apresenta valores altos de coliformes fecais e totais.

A tabela 27 mostra alguns resultados da pesquisa desenvolvida pela UNIVILLE:

Tabela 27: Resultados das análises de água de pocos rasos - Pesquisa para coliformes.

\begin{tabular}{|c|c|c|}
\hline $\begin{array}{c}\text { Nonforme cadastro da } \\
\text { UNIVILLE }\end{array}$ & $\begin{array}{c}\text { NMP de COL TO'TAIS } \\
\text { por } 100 \mathrm{~mL} \text { de água } \\
\text { coletada }\end{array}$ & $\begin{array}{c}\text { NMP de COL. FECAIS } \\
\text { por } 100 \mathrm{~mL} \text { de água } \\
\text { coletada }\end{array}$ \\
\hline $2 / 96$ & $>23$ & $>23$ \\
\hline $8 / 96$ & 6,9 & 1,1 \\
\hline $30 / 96$ & 23 & $<2$ \\
\hline 4796 & 23 & 4,5 \\
\hline $72 / 96$ & 2,2 & $<1,1$ \\
\hline $75 / 96$ & $>23$ & $>23$ \\
\hline $96 / 96$ & $>23$ & 23 \\
\hline $119 / 96$ & 6,9 & 2,2 \\
\hline M.Amaral & 4,5 & $<2$ \\
\hline
\end{tabular}

O cruzamento desta informação com aquelas coletadas ao longo desta pesquisa, sugere que as águas provenientes das entradas de água superficiais não sejam utilizadas (exceto para uso essencialmente industrial) e que seja efetuada uma impermeabilização para evitar contaminação das águas do aqüifero a partir de problemas construtivos. 


\section{7 - Análise da locação dos poços}

A grande maioria dos poços perfurados em Joinville não teve sua locação definida a partir de um estudo hidrogeológico prévio. A locação na realidade obedeceu critérios de ordem prática tais como:

- facilidade de acesso para os caminhões, compressores, perfuratriz e demais equipamentos,

- Limites do terreno do contratante do serviço, portanto sem outras alternativas, e

- Econômico-financeiro: Vender o poço, também faz parte do negócio, mesmo em regiões com baixa densidade de lineamentos.

Devido a este fator notou-se em Joinville que:

- $12 \%$ dos poços perfurados são improdutivos por estarem situados em zonas com ausência de lineamentos,

- $24 \%$ apresentam produtividade entre 1 e $3 \mathrm{~m}^{3} / \mathrm{h}$, por estarem situados em zonas com baixa influência de lineamentos

Porém muitas destas "locações" tiveram a sorte de estar sobre um ou vários lineamentos ou até no raio de influência de lineamentos, o que garantiu vazões razoáveis.

Os poços perfurados a partir de estudos hidrogeológicos prévios (P92, P66, P26 e P106) invariavelmente mostraram grande sucesso nos resultados obtidos. As locações foram efetuadas por geólogos das empresas perfuradoras e levaram em consideração basicamente a fotointerpretação e o levantamento de campo.

Os lineamentos são os principais indicadores de zonas propícias para locação de poços em aqüíferos fraturados e representam os locais com maiores probabilidades de produção de água. A partir disso verificou-se que a execução de estudos hidrogeológicos permite definir o melhor local para a perfuração do poço ou até mesmo a decidir pela não perfuração impedindo que sejam efetuados investimentos em áreas não propícias. 
7.8 - Proposta de áreas favoráveis para a perfuração de poços.

A partir do cruzamento das informaçōes levantadas durante esta pesquisa, elaborou-se um mapa de lineamentos e áreas mais favoráveis à locação de poços tubulares profundos em Joinville - SC, conforme consta no Anexo II.

Esta proposta vem de encontro às necessidades básicas do município e como solução prática e objetiva para o problema de abastecimento de água. Tal proposta não esgota o assunto, pelo contrário, objetiva incitar novos estudos e avanços nesta área de águas subterrâneas, tão importantes para a melhoria de qualidade de vida e que hoje representa a garantia de nosso futuro. 


\section{CONCLUSÕLS}

Joinville, cidade essencialmente industrial, apresenta atividades agrícolas e minerárias em desenvolvimento. O consumo médio de água tratada pela CASAN é de $5.345 \mathrm{~m}^{3} / \mathrm{h}$ adicionada a $690 \mathrm{~m}^{3} / \mathrm{h}$ de água explotada do aqüífero fraturado (utilizada por indústrias, hotéis e condomínios), totalizando $6035 \mathrm{~m}^{3} / \mathrm{h}$.

A definição do potencial hídrico do municipio pautou-se no balanço hídrico desenvolvido e mostrou que:

- A bacia do Rio Cachoeira recebe por ano a precipitação pluviométrica de 1,9 milhões de $\mathrm{m}^{3} / \mathrm{km}^{2}$ de água. A distribuição anual desta água no ciclo hidrológico é assim dividida: Descarga fluvial corresponde a 1,1 milhões de $\mathrm{m}^{3} / \mathrm{km}^{2}$. Evaporação: 0,4 milhões de $\mathrm{m}^{3} / \mathrm{km}^{2}$ e infiltração (que alimenta o aqüffero fraturado): 0,4 milhões $\mathrm{de}^{3} / \mathrm{km}^{2}$.

- A bacia do Rio Cubatão recebe anualmente a precipitação pluviométrica de 3,5 milhões de $\mathrm{m}^{3} / \mathrm{km}^{2}$. A distribuição desta água se faz da seguinte forma: Descarga fluvial: 1,7 milhões de $\mathrm{m}^{3} / \mathrm{km}^{2}$. Evapotranspiração: 1,1 milhão de $\mathrm{m}^{3} / \mathrm{km}^{2}$ e infiltração 0,7 milhão $\mathrm{de} \mathrm{m}^{3} / \mathrm{km}^{2}$.

- A bacia do Rio do Júlio/Itapocuzinho recebe anualmente 1,8 milhões de $\mathrm{m}^{3} / \mathrm{km}^{2}$ de água provindos da precipitação pluviométrica. O balanço hídrico se faz da seguinte forma: Descarga fluvial: 1 milhão de $\mathrm{m}^{3} / \mathrm{km}^{2}$. Evaporação: 0,4 milhão $\mathrm{de} \mathrm{m}^{3} / \mathrm{km}^{2}$ e infiltração 0,4 milhões de $\mathrm{m}^{3} / \mathrm{km}^{2}$.

- A bacia do Rio Pirai recebe anualmente 2,4 milhões de $\mathrm{m}^{3} / \mathrm{km}^{2}$ de água provenientes da precipitação pluviométrica. A evaporação faz retornar ao ciclo hidrológico 1 milhão de $\mathrm{m}^{3} / \mathrm{km}^{2}$. A descarga fluvial transporta cerca de 0,65 milhão de $\mathrm{m}^{3} / \mathrm{km}^{2}$ e a infiltração alimenta os aqüiferos com 0,75 milhão $\mathrm{de}^{3} / \mathrm{km}^{2}$.

Os rios que garantem o abastecimento de $95 \%$ da população de Joinville são o Cubatão e o Pirai.

Os dados oficiais da CASAN apontam perdas no sistema da ordem de $48 \%$ o que representa $2105 \mathrm{~m}^{3} / \mathrm{h}$ que são eliminados por problemas financeiros e físicos. Porém a CASAN espera diminuir estas perdas para $25 \%$. 
A partir disso o déficit do sistema de abastecimento será de $494 \mathrm{~m}^{3} / \mathrm{h}$. Para suprir esta necessidade existe a alternativa de implantar um sistema de abastecimento misto onde a utilização do manancial subterrâneo como fonte complementar, cobriria as necessidades vitais ou seja, 30\% do consumo. A deflagração desta alternativa admite poços tubulares profundos com produção mínima de $10 \mathrm{~m}^{3} / \mathrm{h}$, com as seguintes opções:

- Implantação de uma rede de poços tubulares profundos ao longo dos rios Cubatão e Pirai.

- Implantação de poços tubulares profundos na zona urbana, distribuidos conforme a necessidade de água local.

O aqüifero fraturado de Joinville está caracterizado por rochas Proterozóicas do Escudo Catarinense, com predominância de gnaisse granulítico e subordinadamente gnaisse bandado, quartzito e formações ferríferas. A partir da elaboração de banco de dados com 113 poços tubulares profundos foi possível determinar as características hidrogeológicas deste aqüúfero. O cruzamento das informações cadastradas mostrou que:

1. Os 113 poços cadastrados estão localizados em cotas muito próximas ao nível do mar, variando em média entre 3 e $20 \mathrm{~m}$. Destes, $88 \%$ foram considerados produtivos (vazão acima de $1 \mathrm{~m}^{3} / \mathrm{h}$ ) e $12 \%$ são improdutivos.

2. As primeiras perfurações foram executadas na década de 50. Porém apenas de 1986 a 1995 foram perfurados $72 \%$ dos poços existentes e em 1996 os poços atingiram $10 \%$ do total já perfurado.

3. Com relação às características construtivas constatou-se que:

- O método de perfuração rotativo/percussão foi utilizado em $60 \%$ dos poços enquanto que o método rotopneumático foi utilizado em $40 \%$ e corresponde aos poços mais novos.

- 93,4\% dos poços apresentam revestimento em 6 polegadas $(15,24 \mathrm{~cm})$.

- Em 73,3\% dos poços foram instaladas seções de filtro.

- As profundidades de cimentação do espaço anular para proteção sanitária variam de $5 \mathrm{~cm}$ $(35 \%)$ até $50 \mathrm{~m}(10 \%)$.

- Estas informações relativas a profundidade de cimentação e revestimento dos poços perfurados, quando relacionadas com as características físicas do aqüifero fraturado, principalmente perfil de intemperismo, profundidades de entradas de água e litologia, podem indicar possiveis deficiências de construção dos poços. Portanto, podem fornecer 
critérios para o melhor dimensionamento dos componentes das futuras obras de captação, sobretudo, mais adequados às peculiaridades hidrogeológicas locais.

4. O manto de intemperismo sobre o aqǘffero fraturado é muito desenvolvido devido ao clima predominante, tipos de litologia envolvidas e alta taxa de pluviosidade. Pode chegar até $60 \mathrm{~m}$, porém as maiores ocorrências variam de 30 a $40 \mathrm{~m}$.

5. A profundidade ideal e mais econômica para poços tubulares profundos em Joinville gira em torno de $100 \mathrm{~m}$, uma vez que as principais contribuições de água estão nesta faixa.

6. A análise das frequências de vazão definiu que as maiores produções estão em torno de 1 a $3 \mathrm{~m}^{3} / \mathrm{h}$. Este resultado mostrou que $81,4 \%$ dos poços tubulares perfurados não tiveram estudos preliminares. $8,8 \%$ utilizaram critérios básicos como análises de fotografias aéreas e resultaram vazões entre 9 e $15 \mathrm{~m}^{3} / \mathrm{h}$. Para $5,8 \%$ dos poços foram realizados estudos hidrogeológicos e as vazões obtidas foram entre 15 e $25 \mathrm{~m}^{3} / \mathrm{h}$.

7. O nível estático varia em $61 \%$ dos poços entre $0,7 \mathrm{~m}$ a $6 \mathrm{~m}$. Os rebaixamentos são da ordem de 30 a $50 \mathrm{~m}$ ( $38 \%$ dos poços) e por consequência os níveis dinâmicos mais profundos chegaram a $138 \mathrm{~m}, 90 \mathrm{~m}$ e $80 \mathrm{~m}$.

8. As capacidades especificas apresentaram valores extremamente baixos. $90 \%$ apresentaram valores até $0,5 \mathrm{~m}^{3} / \mathrm{h} . \mathrm{m}$. $7 \%$ variam de 0,5 a $1,0 \mathrm{~m}^{3} / \mathrm{h} . \mathrm{m}$ e apenas $3 \%$ estão acima de $1,0 \mathrm{~m}^{3} /$ h.m. A partir disso deverá ser definido, em estudo específico, como a água se comporta no aqüífero, ou seja como flui e quanto é estocada.

9. As profundidades de entrada de água do aqüifero de Joinville estão concentradas entre $20 \mathrm{e}$ 1.00m (90\%) sendo que a partir dos $40 \mathrm{~m}$ as entradas de água diminuem sensivelmente com o aumento da profundidade.

10. A pesquisa realizada a partir dos lineamentos mostrou que:

- Os sistemas de lineamentos principais apresentam direção N30-40E e N20-30W.

- As frequências de extensão dos lineamentos mostrou que 69,5\% apresenta extensão em torno de 100 a $1000 \mathrm{~m} .29,4 \%$ com extensão de até $2500 \mathrm{~m}$ e $1,1 \%$ acima de $2500 \mathrm{~m}$.

- A análise comparativa entre produtividade, extensão e direção sugere que as estruturas mais produtivas estão direcionadas a NE com extensão média de $1300 \mathrm{~m}$.

11. A pesquisa hidroquímica revelou que:

- As concentrações máximas de componentes orgânicos estão em torno de $3 \mathrm{mg} / \mathrm{L}$ mas as maiores ocorrências apresentam valores entre 0,1 a $1,0 \mathrm{mg} / \mathrm{L}(66 \%)$ 
- $\mathrm{O}$ pH das águas do aqüífero fraturado estão assim distribuídos: 43\% oscilam entre 6,6 a 7,0 $29 \%$ entre 7,1 a $7,5-9,5 \%$ com pH entre 6,0 e 6,5 e $19 \%$ acima de 7,6 .

- A concentração de sulfatos está entre 10 e $20 \mathrm{mg} / \mathrm{L}(66 \%)$ enquanto que em $27 \%$ das análises não foi detectada a presença se sulfatos.

- A pesquisa laboratorial para nitratos mostrou que aproximadamente em $58 \%$ das amostras não foi detectada a presença de nitratos e que as maiores concentrações (21\%) estão entre 0,1 a $1 \mathrm{mg} / \mathrm{L}$.

- A concentração de ferro total em $68 \%$ das análises foi inferior a $0,3 \mathrm{mg} / \mathrm{L} .12,5$ das amostras não apresentaram ferro total e $31 \%$ das amostras apresentaram concentrações superiores a $0,3 \mathrm{mg} / \mathrm{L}$ e portanto, acima da concentração permitida legalmente.

- O diagrama de Piper mostrou que as águas são localmente alcalinas carbonatadas a bicarbonatadas. Legalmente, o decreto 7841 de 08 de agosto de 1945 também ampara o que foi detectado no diagrama de Piper.

Por fim, a proteção dos mananciais subterrâneos é ponto estratégico para o futuro de todas as cidades e obrigatoriamente deverá ser ítem indicador para a análise e aprovação de projetos de atividades (industrial, agrícola, postos de gasolina, entre outras) que serão instaladas. As atividades já implantadas e em operação deverão ser alvo de constante monitoramento para evitar que os mananciais subterrâneos sejam comprometidos. 


\section{RETERENCIAS}

ABNT - ASSOCIAÇÃO BRASILEIRA DE NORMAS TÉCNICAS - Projeto de poço para captação de água subterrânea - NB 588. Rio de Janeiro - RJ - 1990 (a)

ABNT - ASSOCIAÇÃO BRASILEIRA DE NORMAS TÉCNICAS - Construção e captação de água subterrânea - NB 1290. Rio de Janeiro - RJ - 1990 (b).

AGUIAR, A. T. de; ANDRADE, E de P; HIRATA, R.C.A e SILVA, R.G.B DAEL - 10 anos de experiência acumulada na exploração dos recursos hídricos subterrâneos. $3^{\circ}$ Congresso Brasileiro de Águas Subterrâneas. Anais. Volume 1. Fortaleza - Ceará - 1984.

ALBUQUERQUE FLLHO, J.L - Águas subterrâneas: problemas asociados al uso del suelo, in Aspectos geologicos de Proteccion Ambiental. pg 49-63. UNESCO-UNICAMP-PNUMA. Oficina Regional de ciencia y tecnologia de la UNESCO para América Latina y Caribe. 1995.

BIEMI, J. e REYNALD,J.S - Infiltration and Groundwater flow conditions in the fissured precambrian basement (Ivory Coast), in Memoires of the XXIV congress of Iah, As, Oslo pg. 150-158.- 1993.

BAGGIO, S.B - Parecer Técnico n. 022/95. Relatório interno FUNDEMA inédito. Joinville. 1995.

BAGGIO, S.B - Mineração e meio Ambiente em Joinville - SC. Relatório final disciplina Pós graduação PMI700 Mineração e meio ambiente. Escola Politécnica - USP - São Paulo. 1996.

BLACK, J.H - Concepts of flow in fractured rocks, in Isotope Techniques in the study of the hidrology of fractured and fissured rocks. pg 5-15. International Atomic Energy Agency. Viena 1986.

CAVALCANTE, I.N e REBOUÇAS, A.C - Caracterização Hidrogeológica de terrenos cristalinos com manto de alteração, in Revista ÁGUAS SUBTERRÂNEAS - ABAS - n.13 Agosto de 1990. 
CEHPAR - Estudos de simulação do escoamento do Rio Cachoeira. Relatório final. Inédito. Joinville - SC. 1985.

CUBATÃo DRAGAgens - Projeto Ambiental do Morro do Timbé. Proposta de Lavra Mineral e Recuperação Ambiental. Joinville - SC- 1996.

CUSTÓDIO, E. e LLAMAS, MR - Midrologia Subterrânea, Tomo II, Cap.15.3 e 15.4, Adiciones Moega, Barcelona. 1976.

DI BERNARDO, L - Métodos e técnicas de tratamento de ágwa. $2 \mathrm{~V}$ - ABES. Rio de Janeiro$\mathrm{RJ}-1993$.

DT CONSULTORES - EIA/RIMA das obras de dragagem no Complexo Estuarino do Rio Cachoeira e Lagoa do Saguaçu. 7V - Prefeitura Municipal de Joinville. 1991.

DUARTE, U e OLIVEIRA,E - Recursos hídricos in "A Questão Ambiental" - Luiz Edmundo de Magalhães(coordenador) pg.159-183. 1 edição.- Terragraph - São Paulo - SP.

ECOLÓGICA PROIETOS E CONSULTORIA - Plano diretor de abastecimento de água e esgotamento sanitário de Joinville. Relatório de proposições finais. 1994.

ENGEVIX - EIA/RIMA da Usina Hidrelétrica Cubatão. Celesc - Centrais elétricas de Santa Catarina S.A. 5V - Governo do Estado de Santa Catarina. 1989.

ESTEIO ENGENHARIA - Recobrimento aerofotográfico do Município de Joinville - Curitiba - PR. Vôo realizado em 1990

FCTH - FUNDAÇÃO CENTRO TECNOLÓGICO DE HIDRÁULLCA - Barragem do Rio Cubatão - Recomposição emergencial. - Nota técnica 1. Relatório 753 / NT 001-95. Joinville SC. 1995

FOTOAÉREA CRUZEIRO - "Recobrimento aerofotográfico de Joinville" Vôo realizado em $1956-58$. 
GAPLAN - GABINETE DE PLANEIAMENTO E COORDENAÇÃO GERAL - Atlas de Santa Catarina. Rio de Janeiro - RJ. 1986.

GONÇALVES, M.L - Geologia para planejamento de uso e ocupação territorial do município de Joinville. Tese de Doutoramento - Instituto de Geociências - USP. São Paulo. 1993.

GONÇALVES, MLL E DUARTE,U - Água subterrânea na Cidade de JoinvillemSC. In Anais do Congresso Brasileiro de Geologia - Salvador. Bahia. 1996.

IBGE - INSTITUTO BRASILEIRO DE GEOGRAFIA E ESTATISTICA - Folha de Joinville * CARTA GEOGRÁFICA MIR 519. 1983

KRAEMLING, P. - Obras de proteção contra torrentes para evitar danos e enchentes na Bacia do Rio Cubatão, Joinville-SC, Brasil. ABC/FATMA/GTZ/GOPA - Cooperação Técnica Brasil - Alemanha. Relatório inédito FATMA/GTZ. Joinville - SC -1995.

MENEGASSE,L.N - Estudo hidrogeológico das rochas metassedimentares do Crupo São Roque a NW da grande São Paulo - Critérios para locação de poços profundos. Dissertação de Mestrado. IG - USP - São Paulo - SP - 1991.

MIRANDA JÚNIOR, G.X - Relatório das análises de dados fluviométricos e pluviométricos do complexo hídrico da Báa de Babitonga. Centro Integrado de Meteorologia e Recursos hídricos de Santa Catarina - CLIMERH. Florianópolis - SC - 1996.

ODLING, N. E. - An investigation into the permeability of a $2 \mathrm{D}$ natural fracture pattern, in Memoires of the XXIV ${ }^{\text {th }}$ Congress of Iah, As, Oslo. 1993.

PLANEPAR - Estudo hidrológico-sanitário da Bacia do Rio Cubatão Ioinville - SC. CASAN Companhia Catarinense de águas e Saneamento. Relatório Inédito. 1973. 
PREFEITURA MUNICIPAL DE JOINVILLE - Dados Básicos de Joinville. Fundação IPPUJ. Joinville - SC- 1995.

REBOUÇAS, A.C - Impactos Ambientais nas Águas Subterrâneas, in Anais do $7^{\circ}$ Congresso Brasileiro de Águas Subterrâneas - Belo Horizonte -MG- 1992.

SEKHAR, M ; KUMAR, M.S.M E SRIDHARAN, K. - A leaky aquifer model for hard aquifers, in Memoires of the XXIV ${ }^{\text {th }}$ congress of Iah, As, Oslo. Pg.338 348. 1993.

SCHOBBENHAUS, C.; CAMPOS, D.A.; DERZE G.R.; ASMUS, H.E - Geologia do Brasil Texto explicativo do mapa geológico do Brasil e da área oceânica adjacente. Departamento Nacional de Produção Mineral - Brasilia - 1984.

TROISI, S.; VURRO, M. e CASTELLANO, L. - Aspects of hydrodynamics in fissured systems - a comparative study between Iaboratory and in situ tests in: Isotope Techniques in the study of the hidrology of fractured and fissured rocks. pg 17-27. Internacional Atomic Energy Agency. Viena 1989. 


\section{ANCXOS}

Anexo 1 - Mapa Geológico da Área

Anexo 2 - Mapa de lineamentos e de áreas favoráveis à locação de poços tubulares profundos

Anexo 3 - Relação dos Poços Tubulares Profundos 


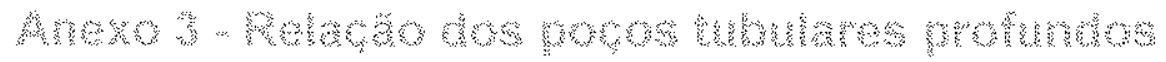

\begin{tabular}{|c|c|c|c|}
\hline POÇO & ANO & PROFUNDIDAD & VAZÃO \\
\hline 1 & 1992 & 85 & 7,92 \\
\hline 2 & 1976 & 112 & 7 \\
\hline 3 & 1991 & 95 & 8,8 \\
\hline 4 & 1993 & 125 & 4,8 \\
\hline 5 & 1994 & 120 & 2,475 \\
\hline 6 & 1994 & 100 & 6,6 \\
\hline 7 & 1990 & 100 & 7,92 \\
\hline 8 & 1989 & 120 & 0,6 \\
\hline 9 & 1991 & 102 & 7,2 \\
\hline 10 & 1994 & 100 & 6,6 \\
\hline 11 & 1995 & 150 & 3,4 \\
\hline 12 & 1990 & 63 & 9,9 \\
\hline 13 & 1990 & 112 & 0 \\
\hline 14 & 1993 & 93,8 & 1,3 \\
\hline 15 & 1996 & 120 & 7,2 \\
\hline 16 & 1992 & 81 & 10,28 \\
\hline 17 & 1989 & 120 & 5 \\
\hline 18 & 1970 & 100 & 10 \\
\hline 19 & 1970 & 110 & 25,2 \\
\hline 20 & 1972 & 100 & 6 \\
\hline 21 & 1976 & 218 & 4,5 \\
\hline 22 & 1977 & 110 & 2,4 \\
\hline 23 & 1979 & 153 & 7 \\
\hline 24 & 1979 & 103 & 24 \\
\hline 25 & 1981 & 120 & 3,6 \\
\hline 26 & 1982 & 180 & 14,12 \\
\hline 27 & 1983 & 200 & 4,5 \\
\hline 28 & 1989 & 100 & 12,3 \\
\hline
\end{tabular}




\begin{tabular}{|c|c|c|c|}
\hline 29 & 1995 & 103 & 11,3 \\
\hline 30 & 1991 & 120 & 1,5 \\
\hline 31 & 1992 & 149 & 0 \\
\hline 32 & 1988 & 100 & 3 \\
\hline 33 & 1992 & 110 & 12 \\
\hline 34 & 1987 & 100 & 1,5 \\
\hline 35 & 1988 & 130 & 3,4 \\
\hline 36 & 1991 & 98 & 16,163 \\
\hline 37 & 1991 & 100 & 3 \\
\hline 38 & 1993 & 100 & 3,6 \\
\hline 39 & 1993 & 100 & 0,833 \\
\hline 40 & 1994 & 100 & 0 \\
\hline 41 & 1985 & 150 & 1,6 \\
\hline 42 & 1988 & 106 & 11,65 \\
\hline 43 & 1995 & 105 & 0,94 \\
\hline 44 & 1905 & 105 & 15,9 \\
\hline 45 & 1985 & 90 & 6,6 \\
\hline 46 & 1977 & 110 & 8,32 \\
\hline 47 & 1987 & 99 & 7,2 \\
\hline 48 & 1989 & 110 & 6.6 \\
\hline 49 & 1993 & 100 & 6,6 \\
\hline 50 & 1994 & 114 & 4,4 \\
\hline 51 & 1995 & 100 & 0 \\
\hline 52 & 1095 & 51 & 17 \\
\hline 53 & 1993 & 100 & 3,5 \\
\hline 54 & 1989 & 150 & 11,4 \\
\hline 55 & 1993 & 100 & 1,6 \\
\hline 56 & 1991 & 130 & 0 \\
\hline 57 & 1988 & 110 & 5 \\
\hline 58 & 1991 & 100 & 2,5 \\
\hline 59 & 1996 & 150 & 0 \\
\hline
\end{tabular}




\begin{tabular}{|c|c|c|c|}
\hline$\theta$ & 1996 & 98 & 3,8 \\
\hline 61 & 1986 & 93 & 15,2 \\
\hline 62 & 1984 & 120 & 11,3 \\
\hline 63 & 1990 & 100 & 1,1 \\
\hline 64 & 1992 & 100 & 16 \\
\hline 65 & 1996 & 45 & 0 \\
\hline 66 & 1993 & 100 & 22 \\
\hline 67 & 1987. & 150 & 1,5 \\
\hline 68 & 1993 & 101 & 6,5 \\
\hline 69 & 1996 & 100 & 6 \\
\hline 70 & 1989 & 134 & 6,6 \\
\hline 71 & 1990 & 50 & 1,7 \\
\hline 72 & 1992 & 110 & 0 \\
\hline 73 & 1991 & 100 & 1,5 \\
\hline 74 & 1988 & 100 & 2,7 \\
\hline 75 & 1987 & 101,5 & 3 \\
\hline 76 & 1989 & 100 & 6 \\
\hline 77 & 1987 & 120 & 8 \\
\hline 78 & 1987 & 112 & 8 \\
\hline 79 & 1987. & 90 & 5 \\
\hline 80 & 1987 & 150 & 5 \\
\hline 81 & 1990 & 74,94 & 20 \\
\hline 82 & 1986 & 111 & 2 \\
\hline 83 & 1987 & 102 & 5 \\
\hline 84 & 1988 & 100 & 1 \\
\hline 85 & 1989 & 119 & 1,2 \\
\hline 86 & 1989 & 130 & 0 \\
\hline 87 & 1989 & 120 & 2,5 \\
\hline 88 & 1988 & 105 & 23 \\
\hline 89 & 1989 & 78 & 7,5 \\
\hline 90 & 1987 & 100 & 3 \\
\hline
\end{tabular}




\begin{tabular}{|c|c|c|c|}
\hline 91 & 1990 & 100 & 7,5 \\
\hline 92 & 1993 & 130 & 22,63 \\
\hline 93 & 1995 & 100 & 8 \\
\hline 94 & 1993 & 150 & 5,3 \\
\hline 95 & 1989 & 0 & 4,7 \\
\hline 96 & 1993 & 140 & 1,95 \\
\hline 97 & 1970 & $41 \ldots$ & 6 \\
\hline 98 & 1970 & 51 & 0,6 \\
\hline 99 & 1971 & 100 & 5 \\
\hline 100 & 1993 & 115 & 2,55 \\
\hline 101 & 1973 & 72 & 8 \\
\hline 1.102 & 1996 & 152 & 6,1 \\
\hline 103 & 1996 & 0 & 0 \\
\hline$\longdiv { 1 0 4 }$ & 1995 & 0 & 0 \\
\hline 105 & 1979 & 70 & 12 \\
\hline 106 & 1979 & 120 & 19 \\
\hline 107 & 1989 & 153 & 8 \\
\hline 108 & 1973 & 101 & 11 \\
\hline 109 & 1977 & 64 & 13 \\
\hline 110 & 1986 & 98 & 0,4 \\
\hline 111 & 1953 & 20 & 1,5 \\
\hline 112 & 1996 & 130 & 0 \\
\hline 113 & 1994 & 130 & 1,8 \\
\hline
\end{tabular}




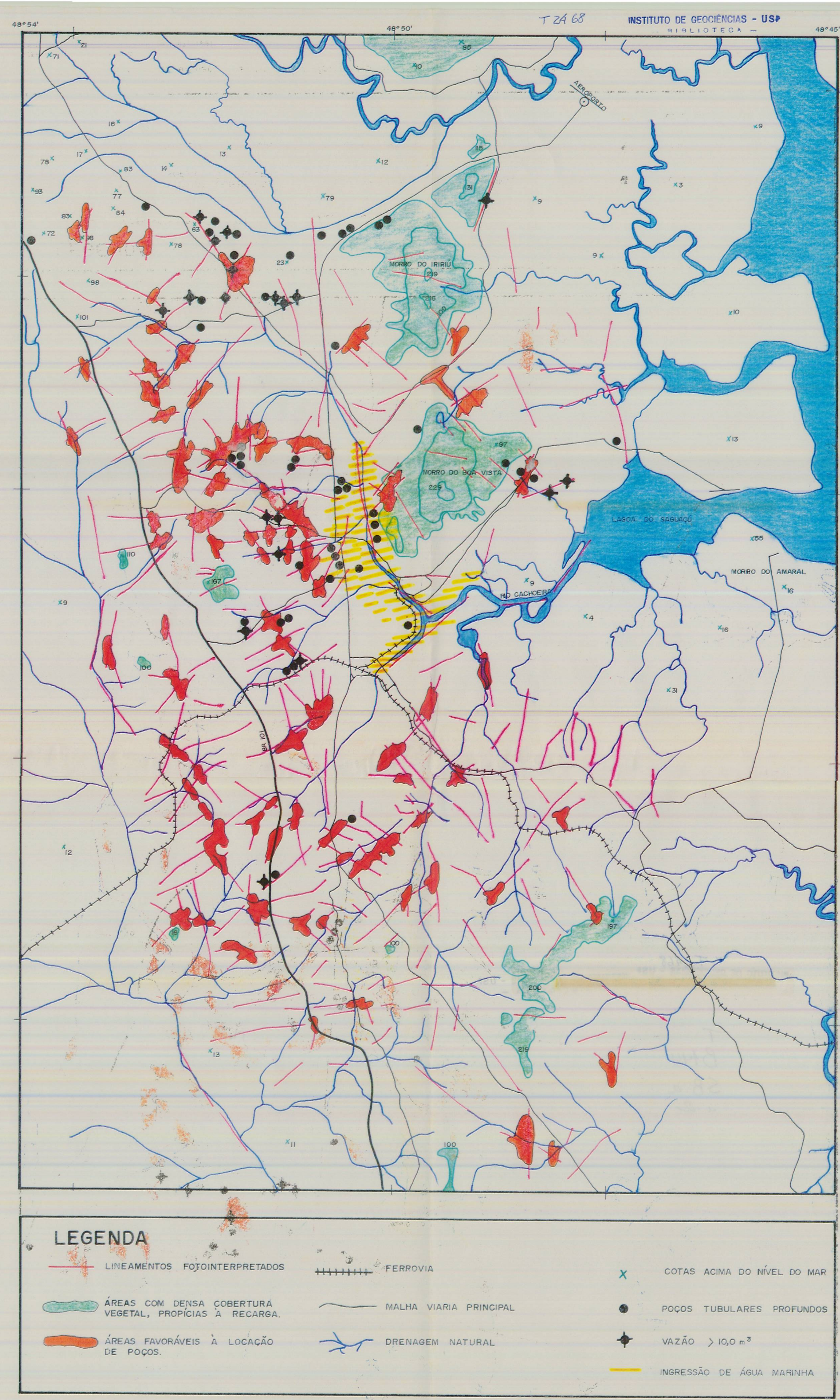

